\title{
The biogeochemistry of nutrients, dissolved oxygen and chlorophyll $a$ in the Catalan Sea (NW Mediterranean Sea)
}

\author{
Mariona Segura-Noguera ${ }^{1,2}$, Antoni Cruzado ${ }^{3,4}$, Dolors Blasco ${ }^{1}$ \\ ${ }^{1}$ Department of Marine Biology and Oceanography, Institut de Ciències del Mar, CSIC, Barcelona, Catalonia. \\ ${ }^{2}$ Present address: ChELSI Institute, Department of Chemical and Biological Engineering, The University of Sheffield, \\ Sheffield, UK. E-mail: mariona@marionasegura.cat \\ ${ }^{3}$ Department of Aquatic Biogeochemistry, Centre d'Estudis Avançats de Blanes, CSIC, Blanes, Catalonia. \\ ${ }^{4}$ Present address: Oceans.cat, Anselm Clavé 8, Blanes 17300, Catalonia.
}

\begin{abstract}
Summary: Reference depth profiles of dissolved inorganic nutrients, dissolved oxygen and chlorophyll $a$ are described for the Catalan Sea using quality controlled data. Phosphate, nitrate and silicate show typical nutrient profiles, with nutriclines at different depths. Maximums of nitrite, dissolved oxygen and occasionally ammonium are found within the photic zone, close to the deep chlorophyll maximum. In intermediate waters we found a minimum of dissolved oxygen coincident with maximum concentrations of phosphate and nitrate. Ammonium concentration is unexpectedly high in the mesopelagic zone, where there are still measurable nitrite concentrations. The origin of such high ammonium and nitrite concentrations remains unclear. We also identify and describe anomalous data and profiles resulting from eutrophication, western Mediterranean Deep Water formation and dense shelf water cascading. The N:P ratio in deep waters is 22.4, which indicates P limitation relative to the Redfield ratio. However, the N:P ratio above the deep chlorophyll maximum in stratified surface waters is $<4$ $(<8$ including ammonium). The depth profiles of key biogeochemical variables described in this study will be a useful reference for future studies in the Catalan Sea (NW Mediterranean Sea) in order to validate data sampled in this area, to identify anomalous processes, and to study the evolution of the ecosystem following the undergoing global change.
\end{abstract}

Keywords: dissolved inorganic nutrients; dissolved oxygen; chlorophyll $a$; stoichiometry; P limitation; NW Mediterranean Sea; Catalan Sea

Biogeoquímica de los nutrientes, oxígeno disuelto y clorofila $a$ en el mar catalán (mar Mediterráneo noroccidental).

Resumen: En este artículo se describen perfiles de profundidad de referencia para nutrientes inorgánicos disueltos, oxígeno disuelto y clorofila $a$ en el Mar Catalán. Estos perfiles se han creado usando datos que han superado un control de calidad. Los perfiles de fosfato, nitrato y silicato son típicos de nutrientes, pero las nutriclinas se encuentran en diferentes profundidades. En la zona fótica, cerca del máximo profundo de clorofila, hay concentraciones máximas de nitrito, oxígeno disuelto y, ocasionalmente, amonio. En aguas intermedias se han detectado concentraciones mínimas de oxígeno disuelto coincidentes con concentraciones máximas de fosfato y nitrato. En la zona mesopelágica se encuentran concentraciones inesperadamente altas de amonio, así como concentraciones de nitrito por encima del límite de detección, cuyo origen se desconoce. En el presente estudio también se identifican y describen datos y perfiles anómalos resultantes de procesos de eutrofización, de formación de agua mediterránea profunda (WMDW), o de cascadas de agua densa (DSWC). La relación N:P en aguas profundas es 22.4 , indicando limitación por fósforo relativo a la relación de Redfield. No obstante, la relación N:P por encima del máximo profundo de clorofila en aguas estratificadas es menor que 4 (menor que 8 si el amonio se incluye en la relación). Los perfiles de profundidad descritos en este estudio son una referencia para futuros estudios en el mar Catalán, útiles para validar datos obtenidos en esta área, para identificar procesos anómalos y para estudiar la evolución del ecosistema como consecuencia del cambio global.

Palabras clave: nutrientes inorgánicos disueltos; oxígeno disuelto; clorofila $a$; estequiometría; limitación por fósforo; mar Catalán; mar Mediterráneo.

Citation/Como citar este artículo: Segura-Noguera M., Cruzado A., Blasco D. 2016. The biogeochemistry of nutrients, dissolved oxygen and chlorophyll $a$ in the Catalan Sea (NW Mediterranean Sea). Sci. Mar. 80S1: 39-56. doi: http://dx.doi. org/10.3989/scimar.04309.20A

Editor: D. Vaqué.

Received: July 1, 2015. Accepted: February 23, 2016. Published: September 30, 2016.

Copyright: ( $) 2016$ CSIC. This is an open-access article distributed under the terms of the Creative Commons Attribution (CC-by) Spain 3.0 License. 


\section{INTRODUCTION}

The Catalan Sea (Fig. 1) is an area of the northwestern Mediterranean Sea that has been thoroughly studied since 1900, with almost yearly oceanographic cruises from 1960 (e.g. Supplementary Material Table S1). As a result of these studies, the dynamics of circulation, phytoplankton composition and primary production of the Catalan Sea are well known. In this study we use quality controlled data from cruises in the Catalan Sea to describe reference concentration depth profiles of key biogeochemical variables, including dissolved inorganic nutrients, dissolved oxygen and chlorophyll $a(\mathrm{Chl} a)$.

The Mediterranean Sea is a concentration basin where evaporation greatly exceeds precipitation and river runoff. The water deficit is compensated for by the entrance of surface waters through the Strait of Gibraltar, while the outgoing flow of deep waters (about $4.7 \%$ nutrient-enriched after spending 75-100 years in the Mediterranean Sea, Cruzado 1985) prevents the accumulation of nutrients in deep Mediterranean Sea waters. As a consequence of this water regime deep water nutrient concentrations are lower than those in the neighbouring Atlantic Ocean (Cruzado 1985). In addition, the Mediterranean Sea is characterized by having almost permanently stratified water columns, though their intensity throughout the year is variable. In stratified water columns the nutrients regenerated in deep waters are prevented from reentering the euphotic zone, where nutrient concentrations are low due to their consumption by osmotrophic organisms (Riley 1971). Consequently, the Mediterranean Sea is an oligotrophic sea, with low levels of Chl $a$ in surface waters, so low levels of primary production are expected.

However, in the western Mediterranean Sea moderate levels of primary production have been recorded, and cannot be explained by the low nutrient content of surface waters. This observation was named by Sournia (1973) the "Mediterranean paradox". In the Catalan Sea, mesoscale structures such as permanent fronts, eddies and filaments favour the upwelling of nutrients to surface waters, allowing the existence of the moderate levels of primary production (e.g. Estrada and Margalef 1988, Salat 1995, Granata et al. 2004). Moreover, the general cyclonic circulation of the Catalan sea creates a central divergence, in which intermediate waters, richer in nutrients than surface waters, are closer to the photic zone, enhancing primary production (Estrada and Margalef 1988, Estrada 1999). However, it is during the late winter months that the most important fertilizing event occurs during the formation of Western Mediterranean Deep Water (WMDW) at the so-called MEDOC area, located between the northern part of the Catalan Sea and south of the Gulf of Lion (Estrada 1996). The WMDW formation is a complex process, which involves strong, cold and dry northerly winds blowing on an area with cyclonic circulation and maximum surface salinity. As a result, a deep convection occurs and the whole water column (from 0 to $2800 \mathrm{~m}$ ) may be homogeneous, leading to the formation of dense water at the surface that rapidly sinks and becomes a new water mass (MEDOC Group 1970, Salat 1983, 1996).

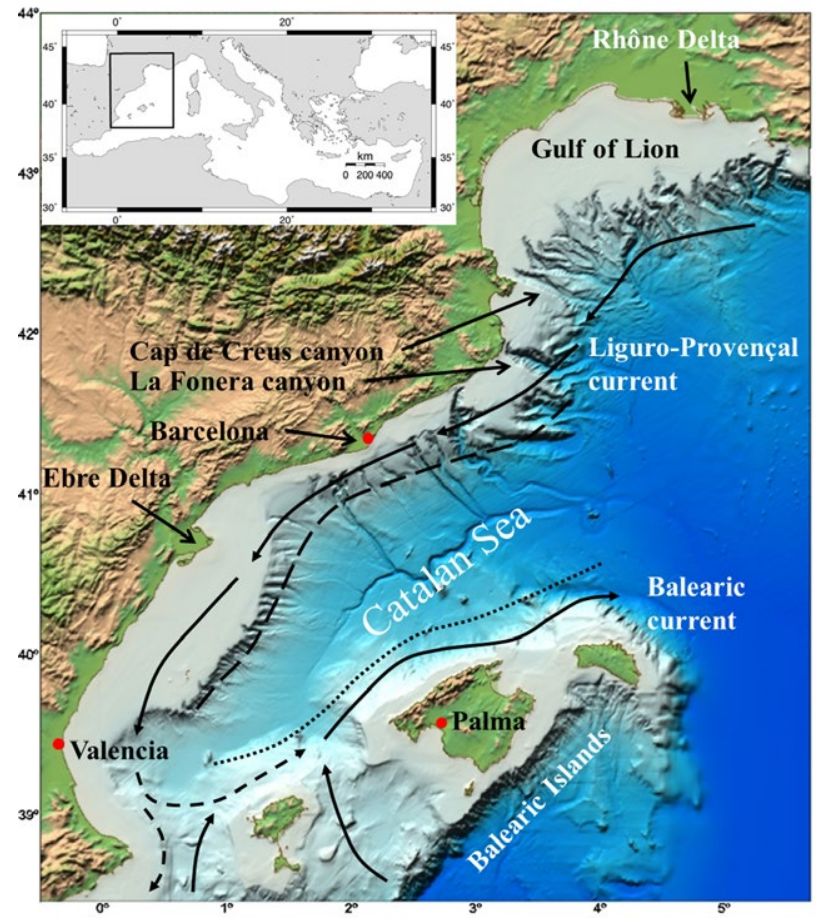

Fig. 1. - Bathymetric map of the Catalan Sea (2005 Catalan-Balearic Sea. Bathymetric Chart and Toponyms, www.icm.csic.es/geo/gma/ MCB/MCBexplora_cat.htm). The pathway of the Liguro-Provençal (or Northern) and Balearic Currents is shown (arrows), as well as an approximate position of the Catalan and Balearic fronts (dashed and dotted lines, respectively), as in Pascual et al. (2002). The inlet map shows the location of the Catalan Sea in the Mediterranean Sea (created using www.aquarius.geomar.de/omc).

Maximum surface $\mathrm{Chl} a$ concentrations are found during winter months (Estrada 1999) and are related to mixing of surface waters with deeper nutrient-rich waters, as well as to continental discharges from the Ebre and Rhône Rivers. The Ebre River collects the runoff from the Pyrenees and wastewater from large cities and intensive agriculture and industry. Its outflow may account for $10-25 \%$ of the total nutrient content in the water column on the adjacent continental shelf (Cruzado et al. 2002, Salat et al. 2002). During the rest of the year, in stratified water column conditions, maximum $\mathrm{Chl} a$ concentrations are found at the deep chlorophyll maximum (DCM), a typical structure found in oligotrophic systems that results from an accumulation of cells actively growing, and an increased pigment content per cell due to photo acclimation (Estrada 1985a). In the Catalan Sea, the DCM is located close to the nitracline, at 40-60 m depth, where there is still enough light (1\% surface radiation) for photosynthesis (Margalef 1985, Estrada 1985b, Bahamón and Cruzado 2003). Coincident with the DCM, the primary nitrite maximum (PNM) is found (Estrada et al. 1993, Bahamón and Cruzado 2003). The coincidence has been explained by the phytoplankton excretion of nitrite as a result of the incomplete nitrate assimilation for cellular requirements (Riley 1971), for example because of the low light intensities (e.g. Blasco 1971, Olson 1981). Finally, a maximum of dissolved oxygen is formed above the DCM as a result of photosynthetic activity 
(Estrada 1999), as found in other parts of the Mediterranean Sea (e.g. Minas and Bonin 1988).

In this study we build up and describe depth concentration profiles of dissolved inorganic nutrients, dissolved oxygen and Chl $a$. To this end, biogeochemical data from cruises in the Catalan Sea were collected. Previously, we used part of this data to build a quality control for dissolved inorganic nutrients, dissolved oxygen and Chl $a$ (Segura-Noguera et al. 2011). In this study we present a complete and exhaustive description of the biogeochemistry of the Catalan Sea made with quality controlled data, including the description of the concentration depth profiles of these basic oceanographic variables, their seasonal variation in surface waters, and the description of the stoichiometry between phosphorus, nitrogen, silicon and apparent oxygen utilization. This basic description of the biogeochemistry of the Catalan Sea will be a useful reference for future studies in the NW Mediterranean Sea, as well as for validating data sampled in the same area, identifying anomalous processes, and studying the evolution of the system during the present global climate change.

\section{MATERIALS AND METHODS}

\section{Circulation and water masses of the Catalan Sea}

The Catalan Sea is the part of the Balearic Sea situated between the northeastern part of the Iberian Peninsula and the Balearic Archipelago (Fig. 1). It is bounded by the Gulf of Lion and the Ligurian Sea in the north and the Balearic Sea in the south. The Catalan Sea is a 400-km-long sub-basin that reaches a maximum depth of $2500 \mathrm{~m}$. Its general circulation is cyclonic, with a central dense water mass surrounded by lighter continental and Atlantic surface waters (Font et al. 1988). Between the central and peripheral waters there are two permanent fronts, the Catalan and the Balearic fronts, which follow the continental shelf-break of the Iberian Peninsula and the Balearic Islands, respectively. The Catalan front is caused by differences in salinity (S) between continental and central waters, while the Balearic front is caused by differences in temperature (T) and $\mathrm{S}$ between Atlantic and central waters (Font et al. 1988). The Catalan current, associated with the Catalan front, is an extension of the Liguro-Provençal Current, also known as the Northern Current. It occupies the top $300-400 \mathrm{~m}$ of the water column, flowing towards the southeast following the 1000 isobath. In front of the Gulf of Valencia, part of this current creates a cyclonic gyre, incorporates Atlantic waters and continues flowing towards the northwest, following the Balearic shelf-break, which generates the Balearic Current (Millot 1987, Font et al. 1988, Salat 1995). The Catalan Current, with average velocities of $20-30 \mathrm{~cm} \mathrm{~s}^{-1}$, has a marked seasonality, its intensity being maximum during autumn and decreasing towards a minimum during summer (Font et al. 1988, Send et al. 1999).

The northernmost continental shelf of the Catalan Sea is narrow (less than $25 \mathrm{~km}$ wide) and irregular due to the presence of submarine canyons, most of which finish in submarine canals (Canals et al. 1982). Submarine canyons and other topographic features, such as the expansion of the continental shelf in front of the Ebre Delta (Fig. 1), lead to deviations of the Catalan Current, creating eddies and intrusions (filaments) of denser and saltier water onto the continental shelf (e.g. Font et al. 1988, Masó et al. 1990, Granata et al. 2004).

In the Catalan Sea four water masses can be found: Surface Water, Winter Intermediate Water (WIW), Levantine Intermediate Water (LIW) and WMDW. Three different surface water masses can be distinguished by their S and location (Salat and Cruzado 1981, Font et al. 1988; Salat 1995): (1) surface water with continental influence is located close to the peninsular coast, containing water from the Rhône and Ebre Rivers, which results in an S of between 35.5 and 37; (2) surface water with Atlantic influence is located close to the Balearic Islands and its $\mathrm{S}$ increases from 36.5 to around 37-37.3 as a result of progressive evaporation from its entrance to the Mediterranean Sea; and (3) resident surface waters (also known as "Mediterranean Waters" or "Modified Atlantic Waters") are located the centre of the basin and have the highest $\mathrm{S}$ (37.8-38) as a result of evaporation during the time spent in the Mediterranean basin.

Below the surface waters, two types of intermediate waters can be found. WIW is formed during winter by convection of surface waters (from both the Gulf of Lion and the Catalan Sea) on the continental shelf, without mixing with deeper waters. It is characterized by a minimum potential temperature of 12 to $12.5^{\circ} \mathrm{C}$ and an $\mathrm{S}$ of 38.1 to 38.3 . The LIW is located between 200 and $600 \mathrm{~m}$, and is the result of the mixing of Levantine water formed in winter in the Aegean Sea and Cyprus with winter water formed in the Adriatic Sea. It is the saltiest water, with a maximum $\mathrm{S}$ of 38.55 and a maximum potential $\mathrm{T}$ of $13.5^{\circ} \mathrm{C}$. In cases of coexistence, WIW is found above LIW (Salat and Font 1987). Finally, the WMDW (MEDOC Group 1970) is found below the LIW down to the bottom of the basin. It has a potential temperature of $12.65^{\circ} \mathrm{C}$ to $12.9^{\circ} \mathrm{C}$, an $\mathrm{S}$ of 38.45 to 38.48 and a density of 29.08 to $29.11 \mathrm{~kg} \mathrm{~m}^{-3}$.

\section{Biogeochemical datasets}

The biogeochemical data used in this study included published historical data, biogeochemical datasets of cruises in which the authors have participated, and data extracted from MEDAR and MEDATLAS databases $\left(0-4.5^{\circ} \mathrm{E}, 38.7-42.5^{\circ} \mathrm{N}\right)$ (Table $\left.\mathrm{S} 1\right)$. Apart from T, S and depth, each cruise included some or all of the following biogeochemical variables: dissolved inorganic nutrients (phosphate, nitrate+nitrite [hereinafter nitrate], nitrite, ammonium and silicate), dissolved oxygen and Chl $a$ concentration. The list of biogeochemical variables available per cruise gathered, as well as the source of the data, is shown in Supplementary Material Table S1. The final dataset was carefully checked to avoid any duplicated data. The whole pool of data was quality controlled using flags: data within the ranges of concentration described in Segura-Noguera et al. (2011) were flagged "0", data above the range were 
Table 1. - Some characteristics of the oceanographic variables of the dataset used in this study: range of years, number of cruises, profiles and data from the continental shelf (stations with a bottom depth $\leq 200 \mathrm{~m}, \mathrm{CS}$ ) and from the open sea (stations with a bottom depth $>200 \mathrm{~m}$, OS). Only data flagged " 0 " during the quality control are included in the Table. In addition, only data above detection limits are included in the case of the dissolved inorganic nitrogen (DIN), apparent oxygen utilization (AOU), oxygen saturation (\% $\mathrm{O}_{2}$ sat) and all the ratios.

\begin{tabular}{|c|c|c|c|c|c|c|c|c|}
\hline \multirow[b]{2}{*}{ Variable } & \multirow[b]{2}{*}{ Range of years } & \multirow[b]{2}{*}{ No. of cruises } & \multicolumn{3}{|c|}{ No. of profiles } & \multicolumn{3}{|c|}{ No. of data } \\
\hline & & & $\mathrm{CS}$ & OS & Total & CS & OS & Total \\
\hline Phosphate & 1957-2004 & 88 & 490 & 731 & 1221 & 2994 & 7478 & 10472 \\
\hline Nitrate & 1979-2004 & 38 & 622 & 1029 & 1652 & 4117 & 11262 & 15379 \\
\hline Nitrite & 1976-2004 & 67 & 538 & 891 & 1430 & 3612 & 9841 & 13453 \\
\hline Ammonium & 1982-2004 & 26 & 247 & 470 & 717 & 1196 & 3180 & 4376 \\
\hline DIN & 1982-2004 & 21 & 139 & 369 & 508 & 416 & 1645 & 2061 \\
\hline Silicate & 1970-2004 & 82 & 620 & 1027 & 1648 & 4235 & 11794 & 16029 \\
\hline Oxygen & $1910-2000$ & 89 & 309 & 679 & 989 & 2119 & 8174 & 10293 \\
\hline AOU, $\% \mathrm{O}_{2}$ sat & 1910-2000 & 74 & 1996 & 649 & 948 & 298 & 7543 & 9539 \\
\hline Chlorophyll $a$ & 1976-2004 & 64 & 468 & 725 & 1194 & 2153 & 6035 & 8188 \\
\hline $\mathrm{N}: \mathrm{P}$ & $1982-2003$ & 23 & 294 & 591 & 885 & 1609 & 4515 & 6124 \\
\hline DIN:P & $1982-2003$ & 20 & 121 & 294 & 414 & 329 & 1022 & 1351 \\
\hline Si:P & 1982-2003 & 22 & 290 & 581 & 871 & 1684 & 4824 & 6508 \\
\hline Si:N & 1979-2003 & 30 & 407 & 877 & 1285 & 2561 & 7921 & 10482 \\
\hline AOU:P & $1970-2000$ & 17 & 154 & 391 & 545 & 762 & 3191 & 3953 \\
\hline AOU:N & 1979-2000 & 24 & 246 & 583 & 830 & 1029 & 5201 & 6515 \\
\hline AOU:Si & $1982-2000$ & 21 & 238 & 571 & 810 & 1440 & 5885 & 7325 \\
\hline
\end{tabular}

flagged " 1 ", and data below the range were flagged " 2 ". In the present study, only data with flag " 0 " (Table 1) were used to describe depth profiles and to characterize water masses. Sampling stations for each oceanographic variable are shown in Supplementary Material, Figure S1. The main features of the analyses of dissolved inorganic nutrient, dissolved oxygen and Chl $a$ of the dataset, when available, are exhaustively described in Segura-Noguera et al. (2011) and summarized below.

Four different autoanalysers were used for nutrient analysis (Technicon, Skalar, Evolution-II of Alliance and AA3 of Bran+Luebbe) following similar methodologies (Hansen and Koroleff 1999). A salicylatehypochlorite method was used for ammonium analysis between 2001 and 2004 (Bower and Holm-Hansen 1980). Until 1999, samples were usually analysed on board, and after that year they were preserved by freezing and analysed on land. Nutrient standards were always prepared at room temperature $\left(20-25^{\circ} \mathrm{C}\right)$. The analysis precision of each biogeochemical variable was estimated for several cruises using different methods (Segura-Noguera et al. 2011). The detection limit for the whole dataset was estimated as three times the average of the analysis precision calculated after removing the outliers with the interquartile method. The resulting detection limits were $0.02 \mu \mathrm{M}$ for phosphate, 0.01 $\mu \mathrm{M}$ for nitrite, $0.08 \mu \mathrm{M}$ for nitrate, $0.07 \mu \mathrm{M}$ for ammonium and $0.12 \mu \mathrm{M}$ for silicate. Detection limits of the 2001-2004 cruises "Canyons" I to IV and "Caco" 1 to 4 were calculated during the present study, and were $0.006 \mu \mathrm{M}$ for phosphate, $0.004 \mu \mathrm{M}$ for nitrite, 0.015 $\mu \mathrm{M}$ for nitrate, $0.020 \mu \mathrm{M}$ for ammonium and $0.017 \mu \mathrm{M}$ for silicate. Nutrient concentrations are given in $\mu \mathrm{M}$

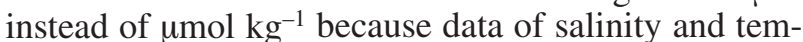
perature were not available for all the corresponding nutrient concentrations. Consequently, the conversion to $u$ mol $\mathrm{kg}^{-1}$ would represent a data loss of around $6 \%$ of inorganic nutrient and up to $11.2 \%$ of ammonium, a very scarce nutrient in our dataset. Except for very few stations close to the Ebre Delta with a freshwater signature, the $\sigma-\mathrm{T}$ range in our dataset is 13.7 to 29.4 $\mathrm{kg} \mathrm{m}^{-3}$. This difference means that the values in $\mu \mathrm{M}$ are

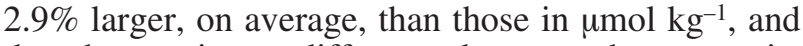
that the maximum difference between the two units (corresponding to the largest concentrations of these variables in the Catalan Sea) are around 0.27 of nitrate, 0.30 of silicate, 0.07 of ammonium, 0.02 of nitrite, 0.01 of phosphate and 8.9 of dissolved oxygen.

Throughout the years, dissolved oxygen was consistently measured following Winkler (1988). The difference between cruises was the method for determining the final titration point, which was visual or automatic. Dissolved oxygen data were converted to $\mu \mathrm{M}$ using the molar volume of oxygen gas $(22.3916 \mathrm{~L}$ $\mathrm{mol}^{-1}$ ) and the density of water at zero pressure calculated with SEABIRD software from CTD temperature $\left({ }^{\circ} \mathrm{C}\right.$, converted to potential temperature with the same software) and salinity (psu). The detection limit of dissolved oxygen of the whole dataset was 7.7 $\mu \mathrm{M}$. All our dissolved oxygen values were above detection limit.

The apparent oxygen utilization $(\mathrm{AOU}, \mu \mathrm{M})$ was calculated as the difference between dissolved oxygen in saturation $\left(\left[\mathrm{O}_{2}\right]^{*}\right)$ calculated from in situ $\mathrm{T}$ and $\mathrm{S}$ following Owens and Millard (1985), and the measured dissolved oxygen in the water $\left(\left[\mathrm{O}_{2}\right]_{\text {meas }}\right)$.

Chl $a$ data were determined fluorometrically after filtering with glass fibre filters and extracting with acetone (Yentsch and Menzel 1963). The average precision of Chl $a$ analysis of all cruises was $0.01 \mu \mathrm{g} \mathrm{l}^{-1}$ (Segura-Noguera et al. 2011).

\section{Depth profiles and stoichiometry}

Depth profiles have been built up for dissolved nutrients, Chl $a$ and dissolved oxygen by calculating the median value at each standard level depth (SLD). SLDs are the depths that have been historically most sampled, and include data comprised between $25 \%$ of the distance with the upper SLD and 75\% distance with the lower SLD. We used the SLDs proposed for the Mediterranean Sea by Fichaut et al. (1997): 0, 5, 10, 20, 30, 40, 50, 60, 80, 100, 120, 160, 200, 250, $300,400,500,600,800,1000,1200,1400,1600,1800$, 2000 and $2500 \mathrm{~m}$. Continental shelf and open sea profiles were differentiated because the area closest to the 
Table 2. - Physico-chemical seasonal properties of depth-averaged (0-100 m) surface water (average \pm standard deviation, number of profiles between parentheses) in the Catalan Sea (NW Mediterranean Sea). Units are $\mu \mathrm{M}$ for nutrients and dissolved oxygen $\left(\mathrm{O}_{2}\right)$, and $\mu \mathrm{g} \mathrm{L}^{-1}$ for chlorophyll $a$. Significant differences $(\mathrm{p} \leq 0.05)$ are indicated with "<" or " $>$ ", while the absence of statistically significant differences is indicated with "=",

\begin{tabular}{|c|c|c|c|c|c|c|c|c|}
\hline Variable & Winter & & Spring & & Summer & & Autumn & \\
\hline Temperature & $14.0 \pm 0.6(41)$ & $<$ & $15.7 \pm 0.9(183)$ & $<$ & $16.9 \pm 0.6(52)$ & $>$ & $16.6 \pm 1.2(66)$ & $>$ \\
\hline Salinity & $38.4 \pm 0.1(42)$ & $<$ & $38.3 \pm 0.2(183)$ & $=$ & $38.3 \pm 0.2(53)$ & $<$ & $38.5 \pm 0.1(66)$ & $=$ \\
\hline Density ( $-\mathrm{T})$ & $28.9 \pm 0.1(41)$ & $>$ & $28.4 \pm 0.2(183)$ & $>$ & $28.0 \pm 0.3(52)$ & $>$ & $28.2 \pm 0.3(66)$ & $<$ \\
\hline Phosphate & $0.09 \pm 0.05(37)$ & $>$ & $0.06 \pm 0.04(140)$ & $=$ & $0.05 \pm 0.02(42)$ & $<$ & $0.11 \pm 0.08(72)$ & $=$ \\
\hline Nitrate & $1.33 \pm 0.48(40)$ & $>$ & $1.03 \pm 0.48(210)$ & $>$ & $0.74 \pm 0.33(48)$ & $<$ & $0.99 \pm 0.56(75)$ & $<$ \\
\hline Nitrite & $0.15 \pm 0.07(35)$ & $>$ & $0.10 \pm 0.05$ (194) & $>$ & $0.05 \pm 0.02(52)$ & $<$ & $0.09 \pm 0.04(58)$ & $<$ \\
\hline Ammonium & $0.75(1)$ & & $0.31 \pm 0.20(14)$ & $=$ & $0.15 \pm 0.13(22)$ & $<$ & $0.33 \pm 0.17(25)$ & \\
\hline Silicate & $1.60 \pm 0.72(41)$ & $=$ & $1.51 \pm 0.59(212)$ & $>$ & $0.99 \pm 0.50(51)$ & $<$ & $1.28 \pm 0.37(78)$ & $<$ \\
\hline Chlorophyll $a$ & $0.54 \pm 0.17(42)$ & $>$ & $0.37 \pm 0.12(112)$ & $=$ & $0.36 \pm 0.13(46)$ & $>$ & $0.26 \pm 0.08$ & $<$ \\
\hline & $258.6 \pm 9.0(16)$ & $>$ & $249.5 \pm 10.8(134)$ & $=$ & $247.9 \pm 11.4(23)$ & $>$ & $240.0 \pm 6.7(40)$ & $<$ \\
\hline$\% \mathrm{O}_{2}$ sat & $100.8 \pm 3.4(16)$ & $=$ & $100.9 \pm 5.2(91)$ & $=$ & $102.9 \pm 5.121)$ & $>$ & $98.4 \pm 3.6(38)$ & $<$ \\
\hline
\end{tabular}

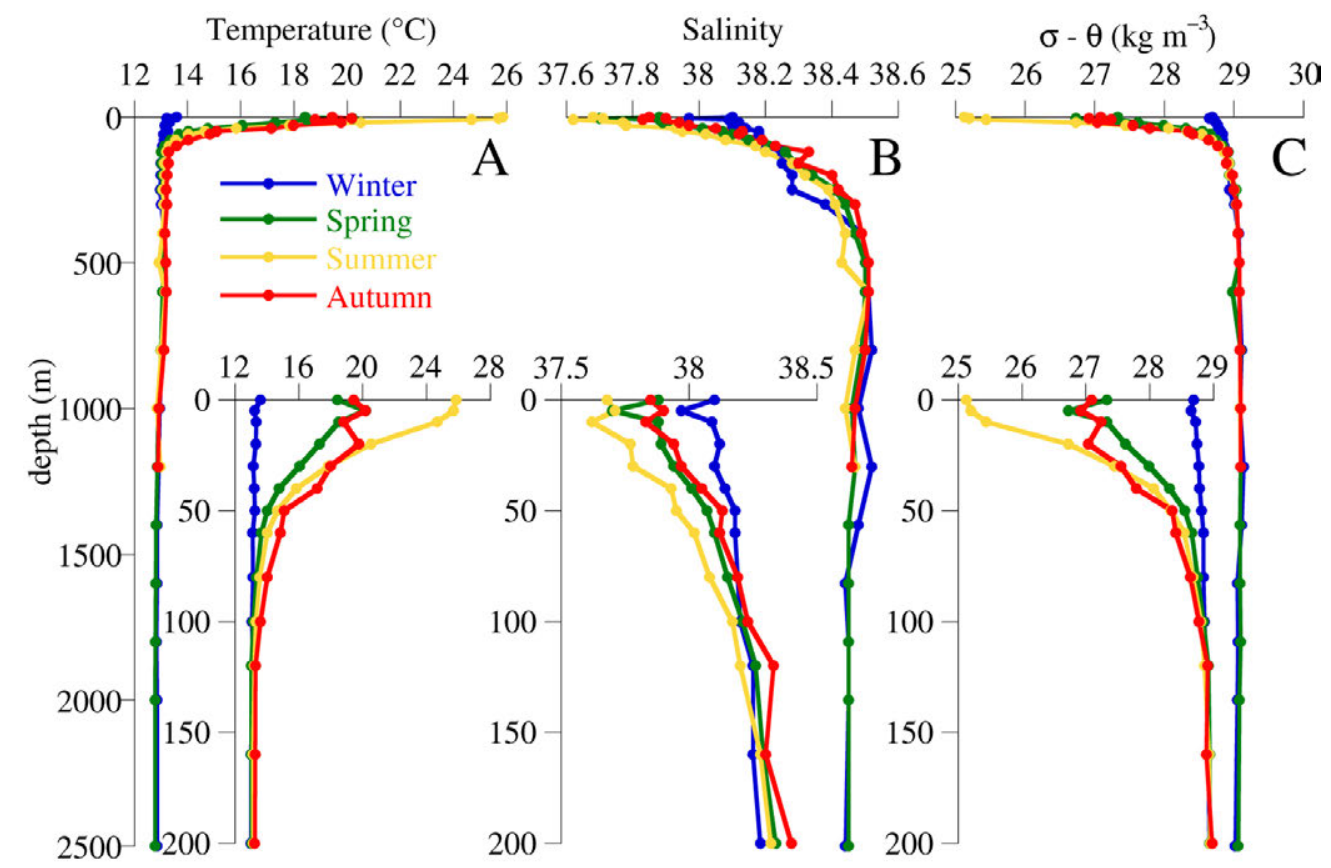

Fig. 2. - Seasonal depth concentration profiles of temperature (A), salinity (B), and density anomaly (C) in open sea stations (bottom depth>200 $\mathrm{m})$ of the Catalan Sea. The first $200 \mathrm{~m}$ are enlarged in the small plots.

coast (bottom depth up to $200 \mathrm{~m}$, as in Fichaut et al. 1997 ) is theoretically influenced by coastal and anthropogenic processes that could presumably increase the concentration of the different oceanographic variables. The data were grouped according to the stratification index estimated for each station and profile depth, as described in Segura-Noguera et al. (2011). The most representative seasons for each stratification index are winter for " 1 ", spring for " 2 ", summer for " 3 " and autumn for "4".

Depth median concentration profiles of each variable, as well as stoichiometry profiles, were created for each stratification index. Depth-integrated (0-100 m) $\mathrm{T}, \mathrm{S}$, density, as well as nutrients, Chl $a$ and dissolved oxygen concentrations, were calculated for surface waters. Seasonal differences in depth-integrated concentrations in surface waters were studied with the PAST software v. 3.06 (Hammer et al. 2001). A univariate non-parametric Kruskal-Wallis test was used to find differences, followed by a post-hoc Mann-Whitney pairwise comparison with Bonferroni corrected $\mathrm{p}$ values. Statistical significance was accepted when $p \leq 0.05$.
The molar stoichiometry between nutrients, as well as between nutrients and dissolved oxygen, were calculated for each available pair of data. Data below the estimated detection limits were not used to calculate the stoichiometry. Element:element correlations were studied using Standard Major Axis (SMA), a model II regression that takes into account differences in the scale of the axes (e.g. N:P relationship). The SMATR software v. 2.0 (Falster et al. 2006) was used to calculate SMA slopes and intercepts, $\mathrm{p}$ values and confidence intervals, and seasonal differences in slopes and intercepts.

\section{RESULTS}

\section{Concentration depth profiles}

Figures 2, 3 and 4 show the seasonal depth profiles of $\mathrm{T}, \mathrm{S}$, density anomaly and biogeochemical variables. The concentration of each variable at each SLD and season can be obtained from Supplemetary Material, Table S2 to S11, and depth-integrated (0-100 m) con- 


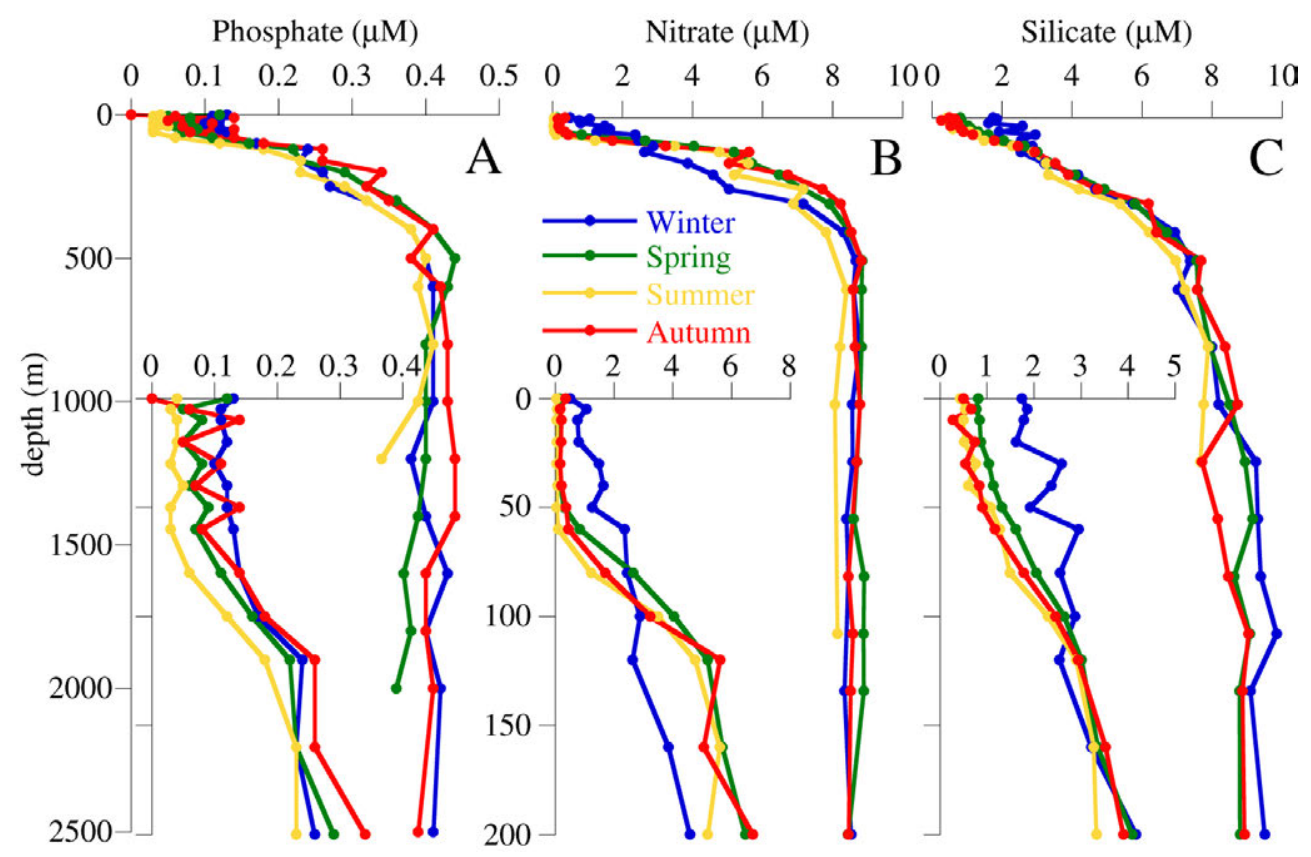

Fig. 3. - Seasonal depth concentration profiles of phosphate (A), nitrate (B) and silicate (C) in open sea stations (bottom depth>200 m) of the Catalan Sea. The first $200 \mathrm{~m}$ are enlarged in the small plots.

centrations are shown in Table 2. A clear seasonality in temperature is found in surface waters (Fig. 2, Table 2). Warming of surface waters in spring outsets the stratification of the water column and the development of a mixed layer. In summer, the mixed layer depth is minimum and a strong thermocline can be observed. The stratification weakens in autumn and the thermocline disappears in winter (Fig. 2). Surface nutrients and Chl $a$ concentration follow the general pattern of thermal stratification, with larger concentrations in winter and minimum surface concentrations during maximal stratification of the water column (Figs 3 and 4).

Phosphate, nitrate and silicate show the typical nutrient depth profile, with low surface concentrations that increase with depth (Fig. 3). At open sea stations, the largest surface $(0-50 \mathrm{~m})$ phosphate, nitrate and silicate concentration is found in winter $(0.11,1.07$ and $1.98 \mu \mathrm{M}$, respectively), and the concentrations decrease throughout spring to reach minimum values in summer $(0.04,0.11$ and $0.63 \mu \mathrm{M}$, respectively). In autumn, nitrate and phosphate concentrations increased, while silicate concentration remained low. Depth profiles from continental shelf stations show a similar pattern, except that summer phosphate concentration is similar to the spring concentration $(0.06 \mu \mathrm{M})$ and nitrate concentration in winter is higher than in the open sea $(1.70 \mu \mathrm{M})$. In winter mixed water columns, nutrient concentration increases linearly from the surface to $400 \mathrm{~m}$ depth at different rates (phosphate 0.7 $\mathrm{nM} \mathrm{m}{ }^{-1}, \mathrm{r}^{2}=0.92$; nitrate $19.4 \mathrm{nM} \mathrm{m} \mathrm{m}^{-1}, \mathrm{r}^{2}=0.98$; silicate $\left.12.7 \mathrm{nM} \mathrm{m}^{-1}, \mathrm{r}^{2}=0.95\right)$. In spring, a nitracline and a phosphocline start to develop in the open sea at 60 and $100 \mathrm{~m}$ depth, respectively. The nitracline is deeper in summer and autumn (80 m, Fig. 3). On the continental shelf, the phosphocline is smoother than in the open sea. Phosphate and nitrate concentrations continue to increase with depth until $500 \mathrm{~m}$. In spring, a maximum concentration of phosphate $(0.44 \mu \mathrm{M})$ can be observed at this depth, but not of nitrate, whose concentration is around $8.6 \mu \mathrm{M}$ from $500 \mathrm{~m}$ to the bottom of the basin. Silicate concentration continues to increase below 500 $\mathrm{m}$ depth, and concentrations around 8.8 to $9.2 \mu \mathrm{M}$ are found below 1200 to $1500 \mathrm{~m}$ depth. The average ( \pm standard deviation) nutrients concentration in deep waters (WMDW with depth $\geq 800 \mathrm{~m}$ ) are $0.40 \pm 0.05 \mu \mathrm{M}$ of phosphate, $8.68 \pm 0.04 \mu \mathrm{M}$ of nitrate and $8.72 \pm 0.91$ $\mu \mathrm{M}$ of silicate.

Ammonium concentration in the open sea (0-200 $m$ depth) is higher in winter, decreasing throughout spring to a minimum in summer (around 0.6, 0.2 and $0.1 \mu \mathrm{M}$, respectively) (Fig. 4). In autumn, ammonium concentration increases again and is higher than that in spring (around $0.4 \mu \mathrm{M}$ ). At continental shelf stations this seasonality cannot be clearly seen, and the largest concentrations are found in winter below $30 \mathrm{~m}$ depth. It is difficult to detect clear features below $200 \mathrm{~m}$ depth because of the scarcity of data. The average concentration below $250 \mathrm{~m}$ depth is around $0.64 \pm 0.34 \mu \mathrm{M}$.

Surface Chl $a$, nitrite and dissolved oxygen concentrations show a similar pattern: highest concentrations in winter, lowest in summer, and a presence of a maximum (Fig. 4). In winter, a high Chl $a$ concentration is found between $0-60 \mathrm{~m}$ (around $0.75 \mu \mathrm{g} \mathrm{l}^{-1}$ in the open sea and $0.61 \mu \mathrm{g} \mathrm{l}^{-1}$ on the continental shelf), and two maximums can be observed, one above $20 \mathrm{~m} \mathrm{(0.86}$ and $0.75 \mu \mathrm{g}^{-1}$ in the open sea and on the continental shelf, respectively) and another at $50 \mathrm{~m}(0.83$ and $0.68 \mu \mathrm{g}$ $1^{-1}$, respectively). The maximum at $50 \mathrm{~m}$ is coincident with a maximum of ammonium and of nitrite, although only in the open sea (1.21 and $0.23 \mu \mathrm{M}$, respectively). Surface Chl $a$, nitrite and dissolved oxygen concentrations decrease in spring. Chl $a$ and nitrite accumulate 
between 40 and $100 \mathrm{~m}$ depth, forming the DCM around 50 to $60 \mathrm{~m}$ depth $\left(0.58\right.$ and $0.49 \mu \mathrm{g}^{-1}$ in the open sea and on the continental shelf, respectively) and PNM around 60 to $80 \mathrm{~m}$ depth $(0.11$ and $0.16 \mu \mathrm{M}$, in the open sea and on the continental shelf, respectively), while dissolved oxygen forms a shallower maximum around 30 to $40 \mathrm{~m}$ depth (261.7 and $262.6 \mu \mathrm{M}$ in the open sea and on the continental shelf, respectively). In summer, the DCM is larger and deeper than in spring $(0.61 \mu \mathrm{g}$ $\mathrm{l}^{-1}$ at $80 \mathrm{~m}$ in the open sea, and $0.62 \mu \mathrm{g} \mathrm{l}^{-1}$ at $60 \mathrm{~m}$ on the continental shelf), as is the dissolved oxygen maximum $(272.9 \mu \mathrm{M}$ at $40 \mathrm{~m}$ in the open sea, and 268.4 $\mu \mathrm{M}$ at $50 \mathrm{~m}$ on the continental shelf). By contrast, the PNM is lower $(0.11$ and $0.08 \mu \mathrm{M}$ in the open sea and on the continental shelf, respectively) and only deeper in the open sea $(80 \mathrm{~m})$. In autumn, surface Chl $a$ and nitrite increase and are similar to spring values, while dissolved oxygen is lower than in spring. The DCM is shallower (around $50 \mathrm{~m}$ ) and lower than during the rest of the year $\left(0.38\right.$ and around $0.3 \mu \mathrm{g} \mathrm{l}^{-1}$ in the open sea and on the continental shelf, respectively), while the PNM is higher on the continental shelf than in the open sea (0.21 and 0.07-0.09 $\mu \mathrm{M}$, respectively). The dissolved oxygen maximum is at the same depth as in summer, but its intensity is much lower $(246.5 \mu \mathrm{M}$ in the open sea, and $242.9 \mu \mathrm{M}$ on the continental shelf).

Below the DCM, the Chl $a$ concentration decreases until it falls below the detection limit around $200 \mathrm{~m}$, except in winter, when concentrations of 0.03 to $0.06 \mu \mathrm{g}$ $1^{-1}$ have been measured between 300 and $600 \mathrm{~m}$ depth. Below the PNM, the nitrite concentration also decreases, but its concentration remains detectable throughout the water column (up to $0.08 \mu \mathrm{M}$ ). Dissolved oxygen concentration decreases below the surface maximum to reach minimum values at 500 to $800 \mathrm{~m}$ depth, although its intensity is variable $(189.8-201.0 \mu \mathrm{M})$, and below $1400 \mathrm{~m}$ to the bottom of the basin it increases again up to around $205.9 \pm 3.64 \mu \mathrm{M}$.

Surface water $(0-50 \mathrm{~m})$ dissolved oxygen concentrations and saturation concentrations plotted vs $\mathrm{T}$ are shown in Figure 5. Open sea stratified surface waters $(0-50 \mathrm{~m})$ of the Catalan Sea are oversaturated in dis-

\section{Dissolved oxygen $(\mu \mathrm{M})$}
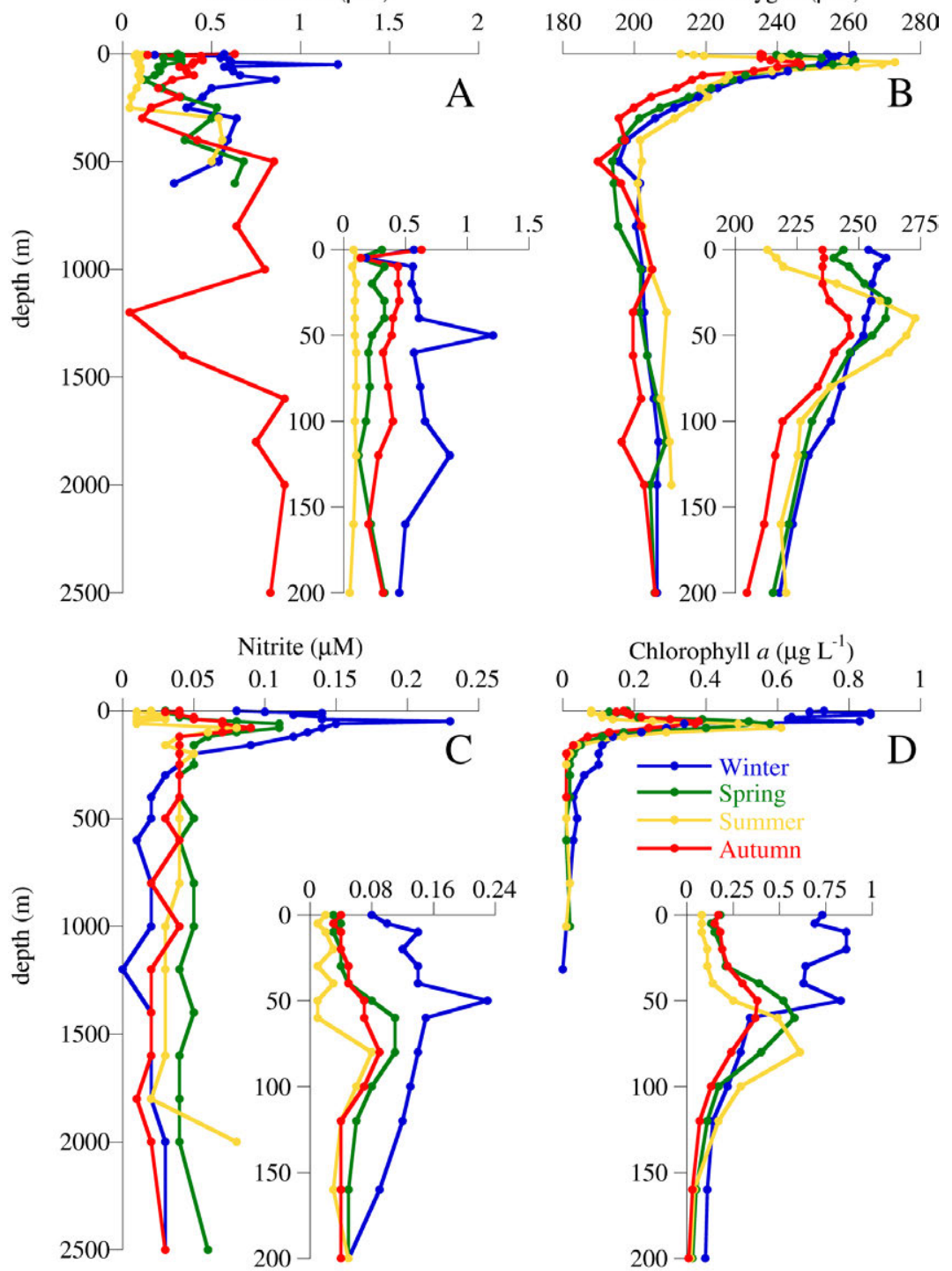

Fig. 4. - Seasonal depth concentration profiles of ammonium (A), dissolved oxygen (B), nitrite (C) and chlorophyll $a$ (D) in open sea stations (bottom depth>200 m) of the Catalan Sea. The first $200 \mathrm{~m}$ are enlarged in the small plots. 


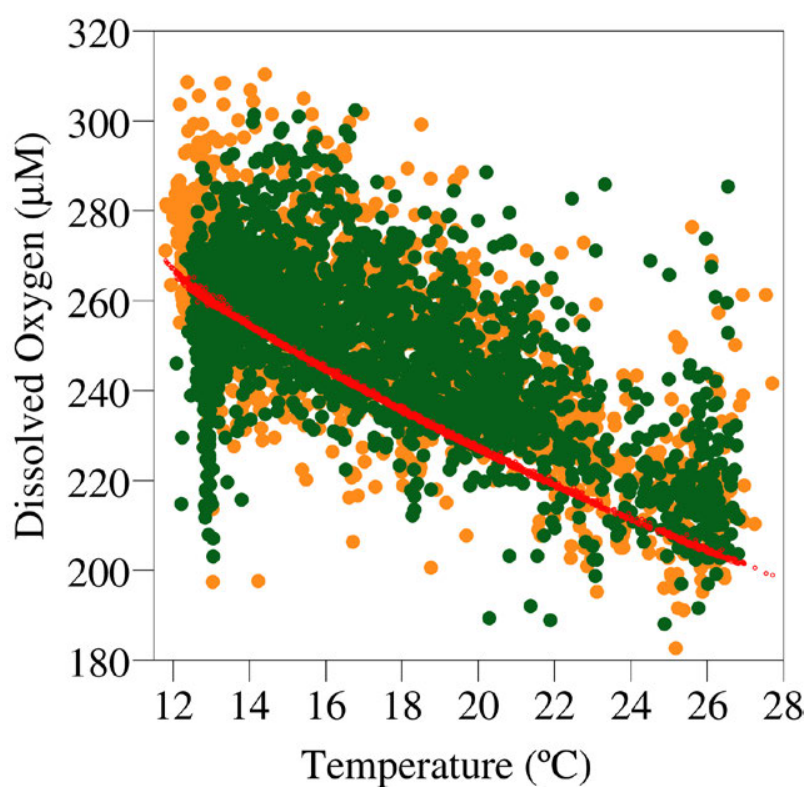

Fig. 5. - Surface water $(0-50 \mathrm{~m})$ dissolved oxygen concentration (green dots: open sea, orange dots: continental shelf), and dissolved oxygen saturation (red, calculated from in situ $\mathrm{S}$ and $\mathrm{T}$ ) as a function of temperature.

solved oxygen (104.9\% in spring, $108.5 \%$ in summer and $101.8 \%$ in autumn). In the open sea mixed water columns are undersaturated in winter (mean value $98.0 \%$ ). This winter value is highly influenced by the low values $(<230 \mu \mathrm{M})$ at $13^{\circ} \mathrm{C}$, which correspond to stations sampled during WMDW formation. On the continental shelf, the oversaturation is found throughout the year in surface waters between 0 and $40 \mathrm{~m}$ in spring $(106.8 \%)$ and between 0 and $50 \mathrm{~m}$ in summer and autumn (107.0\% and $102.3 \%$, respectively), but the oversaturation in the continental shelf mixed water columns is restricted to the upper $20 \mathrm{~m}$ (102.5\% in winter). Both in stratified open sea waters and continental shelf waters, the depth at which the consumption of oxygen exceeds its production, i.e. at which median AOU values turn positive, is just above the DCM. The absolute minimum dissolved oxygen concentration found at 500 to $600 \mathrm{~m}$ depth (189.8-201.0 $\mu \mathrm{M})$, the same depth at which maximum phosphate and nitrate concentrations are found, is corresponded by an absolute maximum of AOU (58.4-69.5 $\mu \mathrm{M}$ ), which represents a consumption of around $23.7 \%$ to $25.2 \%$ of the saturating oxygen.

\section{Stoichiometry}

Surface water ratios are shown in Table 3 . In the open sea, the N:P ratio under stratified conditions (spring to autumn) from 0 to $50 \mathrm{~m}$ depth is lower than the Redfield ratio (median \pm median absolute deviation, 2.6 $\pm 1.3, n=717$ ) (Fig. 6). On the continental shelf, the $\mathrm{N}: \mathrm{P}$ ratio is significantly larger in autumn than in spring and summer. The N:P ratio increases significantly when ammonium is added to the calculations, but it is still below the Redfield ratio. In the open sea, the dissolved inorganic nitrogen (DIN): $\mathrm{P}$ ratio is higher in summer than in spring and autumn, while on the continental shelf the DIN:P ratio in summer and autumn is larger than in spring. In mixed water winter conditions, the $\mathrm{N}: \mathrm{P}$ ratio is higher and more variable. Below the photic layer (around $200 \mathrm{~m}$ depth to the bottom of the basin) the average \pm standard deviation $\mathrm{N}: \mathrm{P}$ ratio is $22.6 \pm 5.7$ $(n=1203)$, and DIN:P is 21.9 $\pm 5.8(n=194)$. This values are similar to the slopes obtained with regression lines for all N:P $\left(22.6, \mathrm{r}^{2}=0.646, \mathrm{n}=6560\right)$ and DIN:P data $\left(22.2, \mathrm{r}^{2}=0.578, \mathrm{n}=1605\right)$, which are significantly different from $16(\mathrm{p} \leq 0.001)$ (Table 4). Lower DIN:P compared with N:P ratios are a consequence of using different datasets, since not all the variables are analysed in all the cruises (See Table S1).

Median Si:N ratio shows a clear seasonality in surface open sea waters $(0-50 \mathrm{~m})$, with a significantly lower value in winter and a higher value in summer, in terms of both average and standard deviation (Fig. 6, Table 3). The median Si:N is not different from spring to autumn (pooled $\mathrm{Si}: \mathrm{N}=4.4 \pm 2.7, \mathrm{n}=1825$ ). As in the open sea, the lowest $\mathrm{Si}: \mathrm{N}$ ratio on the continental shelf is found in winter, and there are no significant differences between the ratio from spring to autumn (pooled ratio: $5.3 \pm 2.6, \mathrm{n}=1108)$. Below $1200 \mathrm{~m}$ depth average, the $\mathrm{Si}: \mathrm{N}$ concentration is $1.0 \pm 0.1(\mathrm{n}=144)$. In surface waters $(0-50 \mathrm{~m})$ median $\mathrm{Si}: \mathrm{P}$ ratios are highly variable (Fig. 6, Table 3) and, as for the Si:N ratio, the largest values are in winter and the lowest are in autumn in the open sea, and in summer on the continental shelf (Table $3)$. In the open sea, Si:P ratios in spring and summer are the same (pooled ratio: $16.3 \pm 9.1, \mathrm{n}=854$ ). Below 1200 $m$ depth, the average $\mathrm{Si}: \mathrm{P}$ ratio is $23.2 \pm 3.4(\mathrm{n}=69)$.

The SMA regression slopes of AOU:P and AOU:N are $150.2\left(r^{2}=0.353, n=1420\right)$ and $8.9\left(r^{2}=0.603, n=1864\right)$ (Table 4). The scatter plots in Figure 7 show that Si:N, Si:P and AOU:Si relationships are not linear, since

Table 3. - Seasonal changes in the nitrate (N), dissolved inorganic nitrogen (DIN) and silicate (Si) vs. phosphate (P), and silicate vs. nitrate ratios in surface water (0 to $50 \mathrm{~m}$ depth). Ratios are shown as median \pm median absolute deviation; number of data between parentheses. Significant differences $(p \leq 0.05)$ are indicated with " $<$ " or " $>$ ", while the absence of statistically significant differences is indicated with " $=$ ". "n.d.", no data.

\begin{tabular}{|c|c|c|c|c|c|c|c|c|}
\hline Ratio & Winter & & Spring & & Summer & & Autumn & \\
\hline Open Sea & & & & & & & & \\
\hline$N: P$ & $17.3 \pm 12.6(515)$ & $>$ & $2.5 \pm 1.3(453)$ & $=$ & $3.0 \pm 1.4(66)$ & $=$ & $2.8 \pm 1.3(198)$ & $<$ \\
\hline DIN:P & n.d. & & $5.9 \pm 2.8(107)$ & $<$ & $7.5 \pm 3.4(34)$ & $>$ & $4.1 \pm 1.9(82)$ & \\
\hline Si:P & $23.5 \pm 15.2(561)$ & $>$ & $15.8 \pm 9.3(746)$ & $=$ & $17.2 \pm 8.1(109)$ & $>$ & $8.1 \pm 7.1(189)$ & $<$ \\
\hline Si:N & $1.5 \pm 0.6(644)$ & $<$ & $4.7 \pm 2.8(1400)$ & $=$ & $6.0 \pm 2.8(146)$ & $=$ & $2.6 \pm 1.4(279)$ & $>$ \\
\hline \multicolumn{9}{|c|}{ Continental Shelf } \\
\hline $\mathrm{N}: \mathrm{P}$ & $25.8 \pm 13.4(388)$ & $>$ & $2.5 \pm 1.3(248)$ & $=$ & $2.5 \pm 1.0(108)$ & $<$ & $3.7 \pm 1.4(191)$ & $<$ \\
\hline DIN:P & $22.1 \pm 10.4(68)$ & $>$ & $6.1 \pm 3.09(40)$ & $<$ & $10.7 \pm 5.5(34)$ & $=$ & $11.0 \pm 6.6(47)$ & $<$ \\
\hline $\mathrm{Si}: \mathrm{P}$ & $40.3 \pm 19.9(406)$ & $>$ & $17.7 \pm 10.1(302)$ & $=$ & $9.9 \pm 4.4(118)$ & $<$ & $16.3 \pm 4.6(216)$ & $<$ \\
\hline $\mathrm{Si}: \mathrm{N}$ & $1.4 \pm 0.4(447)$ & $<$ & $5.4 \pm 2.6(758)$ & $=$ & $4.5 \pm 2.2(132)$ & $=$ & $5.0 \pm 2.5$ & $>$ \\
\hline
\end{tabular}



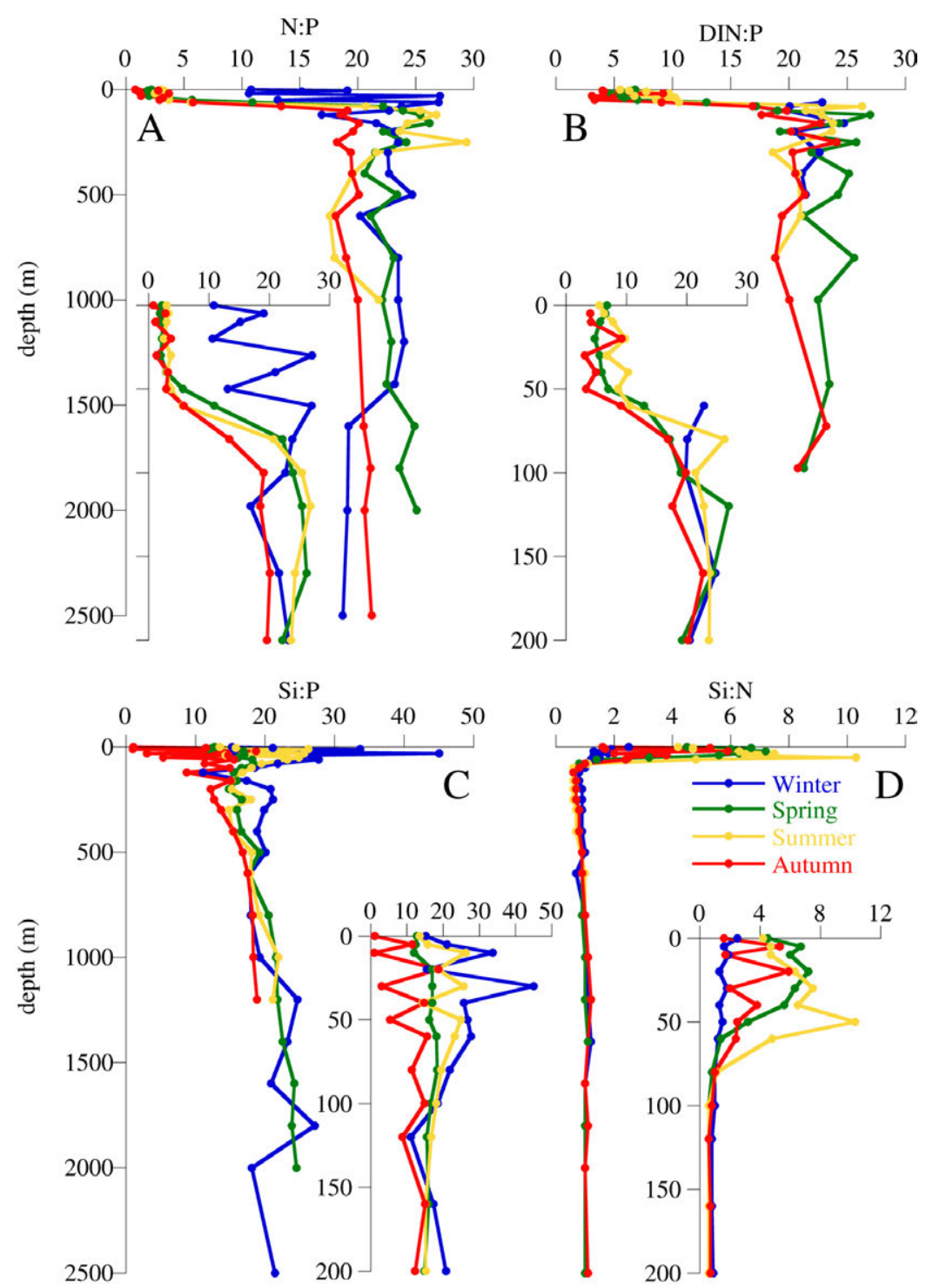

Fig. 6. - Seasonal stoichiometry depth profiles of N:P (A), dissolved inorganic nitrogen (DIN=NO $\left.\mathrm{N}_{2+3}+\mathrm{NH}_{4}\right): \mathrm{P}(\mathrm{B}), \mathrm{Si}: \mathrm{P}(\mathrm{C})$, and $\mathrm{Si}: \mathrm{N}(\mathrm{D})$ at open sea stations (bottom depth>200 m) of the Catalan Sea. The first $200 \mathrm{~m}$ are enlarged in the small plots.

Table 4. - Results of the standard major axis regressions of nitrate (N), dissolved inorganic nitrogen (DIN) and apparent oxygen utilization (AOU) vs. phosphate $(\mathrm{P})$, and AOU vs. nitrate in the Catalan Sea. Shown are the y-intercept and the slope of the regression equations, the interval of confidence (Low CI and Upp CI), the coefficient of determination $\left(\mathrm{r}^{2}\right)$, and the number of data points included (n). All slopes and intercepts, except the AOU:P intercept, are significantly different from $0(\mathrm{p} \leq 0.001)$.

\begin{tabular}{lcccccccc}
\hline Ratio & intercept & Low CI & Upp CI & slope & Low CI & Upp CI & $\mathrm{r}^{2}$ & $\mathrm{n}$ \\
\hline N:P & -0.71 & -0.78 & -0.64 & 22.62 & 22.29 & 22.94 & 0.646 & 6560 \\
DIN:P & -0.77 & -0.92 & -0.62 & 22.23 & 21.53 & 22.94 & 0.578 & 1605 \\
AOU:P & -0.18 & -2.19 & -1.82 & 150.2 & 144.0 & 156.6 & 0.353 & 1420 \\
AOU:N & -12.5 & -14.4 & -10.6 & 8.89 & 8.64 & 9.15 & 0.603 & 1864 \\
\hline
\end{tabular}

silicate concentration still increases below the depth at which phosphate and nitrate have been completely remineralized, corresponding to the WMDW and the deepest LIW (from 500-600 m depth). Therefore, we have not calculated the linear relationship for these ratios. The average AOU:Si calculated from pairs of data in deep waters $(>1200 \mathrm{~m}$ depth) is $6.06 \pm 0.7(\mathrm{n}=58)$.

\section{DISCUSSION}

In this study we have used quality-controlled data from the Catalan Sea to build seasonal depth profiles of dissolved inorganic nutrients, oxygen and $\mathrm{Chl} a$, and to study nutrients and dissolved oxygen stoichiometry in the water column. These general profiles are useful as reference values for future biogeochemical studies in the Catalan Sea. Furthermore, they allow the identification of anomalous profiles resulting from eutrophication, WMDW formation and dense shelf water cascading (DSWC). Below we describe depth profiles of key biogeochemical variables, comparing them with other areas of the Mediterranean Sea and of the global oceans. We show and discuss anomalous profiles and describe surface seasonality and stoichiometry. 

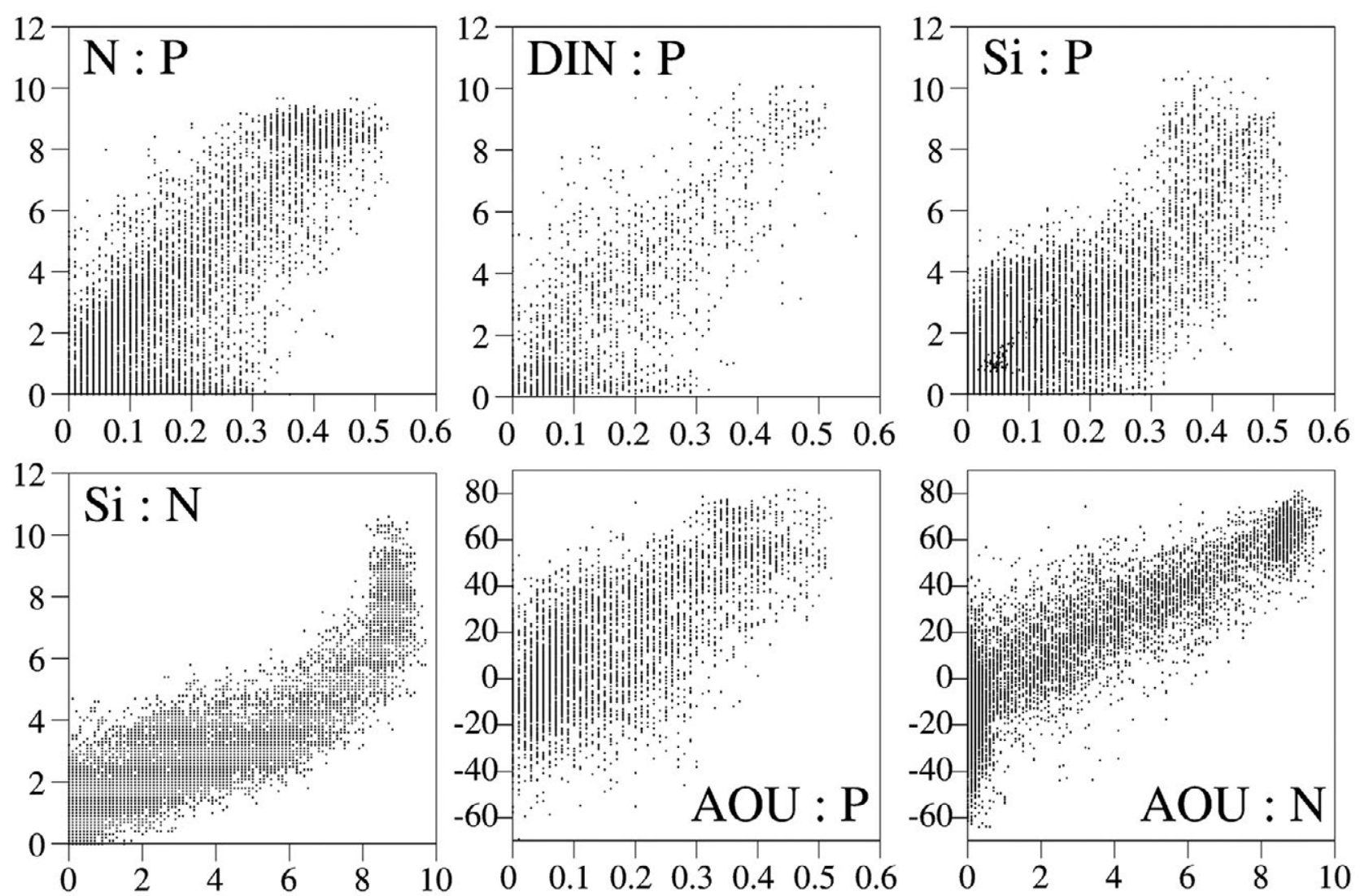

Fig. 7. - Scatter plots of nitrate vs. phosphate (N:P), dissolved inorganic nitrogen vs. phosphate (DIN:P), silicate vs. phosphate (Si:P), silicate vs. nitrate $(\mathrm{Si}: \mathrm{N})$, apparent oxygen utilization vs. phosphate (AOU:P) and AOU vs. nitrate (AOU:N).

\section{Concentration depth profiles}

Depth distribution of phosphate, nitrate and silicate described in this study (Fig. 3) show the typical nutrient profile, with low surface concentrations due to their assimilation by phytoplankton and other osmotrophic organisms, followed by an increase in concentration with depth, as described in other parts of the NW Mediterranean Sea (e.g. Marty et al. 2002 at the neighbouring DYFAMED site). Deep water phosphate, nitrate and silicate concentrations are in agreement with published concentrations from the western Mediterranean Sea (e.g. Ballester et al. 1967, Cruzado 1985, Béthoux et al. 1998).

Maximum concentrations of phosphate and nitrate in intermediate waters have been observed in other areas of the Mediterranean Sea (around 400-700 m, Béthoux et al. 1998, Moutin and Raimbault 2002). Although a clear maximum cannot always be distinguished in our seasonal median profiles, the observation of individual profiles confirms the presence of higher nitrate and phosphate concentrations between 500 and $800 \mathrm{~m}$ depth that follow the pattern of the depth profiles of salinity. In addition, we have also observed in individual profiles the occasional presence of a nutrient peak between 150 and $300 \mathrm{~m}$ depth, associated again with a peak in salinity. Although the intensity of this peak is variable, it can still be observed in the median profiles of nitrate and phosphate (Fig. 3).
A maximum of nutrients and AOU associated with a minimum of dissolved oxygen (100-1000 m) is a feature present in most oceans in the mesopelagic zone (Sarmiento and Gruber 2006), and between 400 and $800 \mathrm{~m}$ depth in other areas of the NW Mediterranean Sea (e.g. Marty et al. 2002, Moutin and Raimbault 2002). It has been associated with both animal respiration and active microbial remineralization of organic material, mostly dead phytoplankton, faecal pellets and other detrital particles that sink from surface waters (e.g. Sarmiento and Gruber 2006). Large zooplankton organisms and micronekton also play an important role in transporting dissolved organic carbon and nutrients from surface waters to the mesopelagic zone through diel vertical migrations (e.g. Longhurst and Harrison 1988, in the NW Mediterranean Sea: Isla et al. 2015). A higher abundance of animals and microbes at a certain depth of the mesopelagic zone (for example because of the accumulation of sinking organic matter in the interface of two water masses of different density such as WIW and LIW or LIW and WMDW) could lead to the accumulation of nutrients, and hence to the formation of a maximum. Also, the association of the nutrients maximum and dissolved oxygen minimum with salinity indicates that their origin is the remineralization of surface organic matter that has been trapped within the LIW (or WIW) during its formation and sinking. It is unlikely that the decrease in nitrate from this maximum to the bottom of the basin (Fig. 3) is due to denitrifi- 
cation, since this process requires lower oxygen concentrations than those measured at deep Catalan Sea waters (Riley 1971, Millero 1996).

Phosphate and nitrate concentrations remain approximately constant below the maximum in intermediate waters to the bottom of the basin, indicating that all the labile phosphate and nitrate contained in sinking organic matter have already been remineralized. On the other hand, silicate concentration steadily increases from the surface to $1400 \mathrm{~m}$ depth, from where it remains constant down to the bottom of the basin. This difference in the nutrient profiles is a consequence of the slow chemical dissolution of siliceous diatom frustules throughout the water column, as opposed to the active remineralization of phosphate and nitrate, carried out mainly by bacteria and other protozoa (Millero 1996). The different remineralization rates between these nutrients results in the non-linearity of the Si:N, Si:P and AOU:Si ratios, as opposed to AOU:P, AOU:N and $\mathrm{N}: \mathrm{P}$, as can be observed in Figure 7.

A statistically significant relationship between the depths of the DCM, the PNM and the nitracline has been described in the Catalan Sea (Estrada 1999) using a small set of stations from cruises included in the present study (Fronts 90, 91, 92 and Varimed 93). Estrada (1999) compared the position of the maximums and nitracline at 58 stations, showing that the PNM was almost coincident with the nitracline, the DCM was slightly above them, and finally the maximum of dissolved oxygen was the shallowest. This pattern is almost the same as that resulting from comparing our median profiles, except that in our profiles the DCM is found at the same depth as both the PNM and the nitracline in winter and summer, and immediately below them in spring and autumn (Fig. 4). However, the observation of individual profiles shows that these maximums are not always coincident, even on consecutive days of the same cruise. This differences could be related to changes in the nitrite release by phytoplankton at the DCM driven by light or nutrient availability, which could also affect the abundance and/or activity of nitrifiers. Unfortunately, there are no data about light or organisms abundances in our dataset that could help us to understand the relative changes in the peaks position.

In other oligotrophic areas (North Pacific, Bering Sea, Greenland Sea, Sargasso Sea and Gulf Stream) a maximum ammonium concentration has been detected close to the thermocline (i.e. under stratified conditions) and to the DCM (e.g. Saino et al. 1983, Brzezinski 1988), indicating the importance of recycled production in oligotrophic seas. The examination of individual profiles also confirms the accumulation of ammonium around the DCM and PNM in stratified surface waters. However, this pattern is not reflected in the median profiles because a clear peak is not always observed (Fig. 4). On the other hand, under mixed water conditions in the Catalan Sea, an absolute maximum of the median ammonium concentration $(1.21 \mu \mathrm{M})$ is commonly observed at $50 \mathrm{~m}$, overlapping with a relative maximum of Chl $a$ and an absolute maximum of nitrite.
The analysis of ammonium is very sensitive to environmental contaminants and processes both in situ and on land (e.g. cleaning products, smoke, unclean glassware or freezing as a preservation method, see Holmes et al. 1999). Thus, large ammonium concentrations are usually discarded under the assumption of possible sampling or analysis contamination. Taking into account the ease of contamination, the lack of sampling details and the scarcity of the ammonium dataset, the clear seasonality found is striking. Ammonium concentrations in open sea surface waters follow the same seasonal pattern as phosphate, nitrate and silicate, with the highest concentrations in winter and the lowest in summer. The accumulation of ammonium in surface waters demonstrates an imbalance in the productionconsumption processes, especially in winter, when the highest primary production takes place. In the North Atlantic Ocean an increase in ammonium concentration has been described after a silicate-limited diatom bloom, which reversed the direction of the air-sea flux of this nutrient (Johnson et al. 2007). The molecules of atmospheric ammonium suffer a series of chemical reactions and can act as cloud condensation nuclei (Johnson et al. 2007). The winter-spring phytoplankton maximum in the Catalan Sea is dominated by diatoms (Estrada et al. 1999) and, although it is most probably not silicate-limited (Si:N and $\mathrm{Si}: \mathrm{P}$ ratios in winter surface waters are larger than in deep waters, Fig. 6), the accumulation of ammonium (median $\sim 0.6 \mu \mathrm{M}$, similar to that in the study of Johnson et al. 2007) indicates that a release of ammonium to the atmosphere could also be happening in the NW Mediterranean Sea during winter, a hypothesis that remains to be quantified.

Ammonium and nitrite concentrations are still measurable below the euphotic layer, throughout the water column (below 400 m depth: $0.59 \pm 0.36 \mu \mathrm{M}$ ammonium and $0.04 \pm 0.02 \mu \mathrm{M}$ nitrite, Fig. 4). This result is unexpected in an oxic environment like the Catalan Sea, and the origin of such high values remains unclear. Relatively high ammonium concentrations $(0.4$ $\mu \mathrm{M}$ at $800 \mathrm{~m}$ depth) in deep waters have also been reported in another oligotrophic area, the North Pacific Subtropical Gyre (Karl and Knauer 1984). The authors suggested that its origin was the chemolithotrophic activity associated with sinking particles, and their accumulation was the result of the inefficiency of the aphotic microbial community to use them (Karl and Knauer 1984). Assuming that the amount of sinking particles is proportional to surface water primary production, our average ammonium concentration is larger than that measured in the North Pacific Subtropical Gyre, both systems having similar primary production estimates: 300 to $400 \mathrm{mg} \mathrm{C} \mathrm{m}^{-2}$ day $^{-1}$ in the western Mediterranean (Estrada 1996) and $463 \mathrm{mg} \mathrm{C} \mathrm{m}^{-2}$ day $^{-1}$ in the North Pacific Subtropical Gyre (Karl et al. 1996). However, in the Catalan Sea, additional particles from the shelf and slope can also reach the water column, e.g. through nepheloid layers, trawling (e.g. Palanques et al. 2006) or DSWC (see below). Also, several studies point out that surface particulate organic matter in the NW Mediterranean Sea is N-rich (e.g. Copin-Montégut and Copin-Montégut 1983, Mostajir et al. 1998). There- 

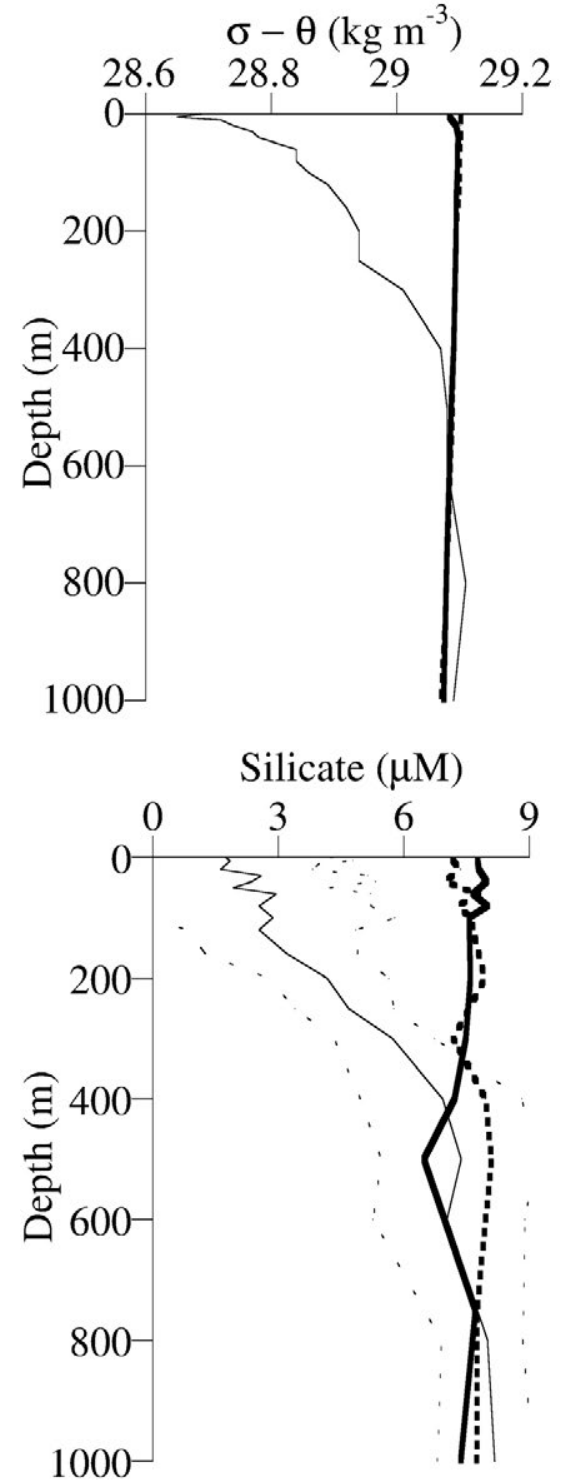

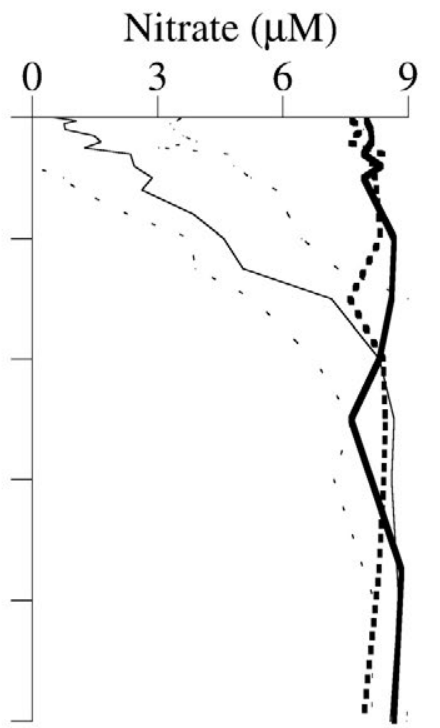

Dissolved oxygen $(\mu \mathrm{M})$

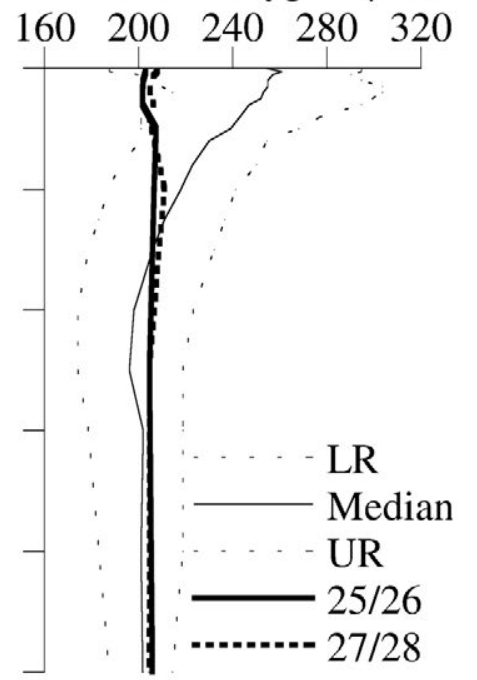

Phosphate $(\mu \mathrm{M})$

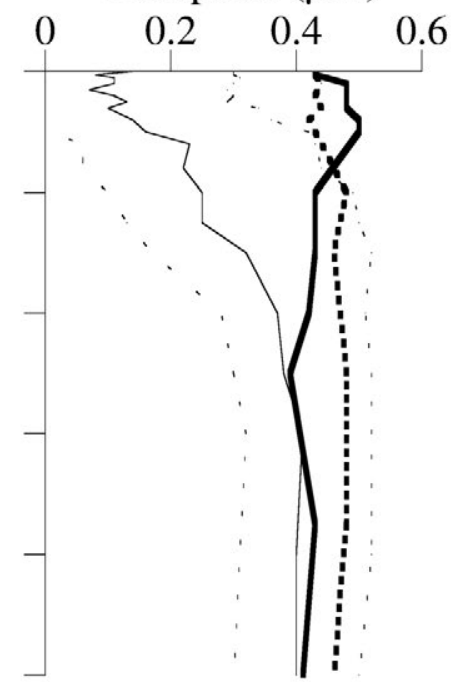

Chlorophyll $a\left(\mu \mathrm{g} \mathrm{L}^{-1}\right)$

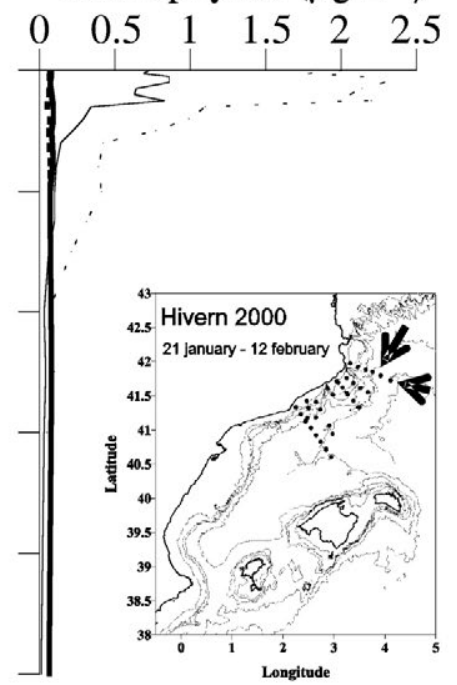

Fig. 8. - Depth profiles of density anomaly, phosphate, nitrate, silicate, dissolved oxygen and chlorophyll $a$ of two stations of the Hivern2000 cruise in the WMDW formation area. The arrows in the inlet map point towards the position of stations $25 / 26\left(41.80^{\circ} \mathrm{N} 3.92^{\circ} \mathrm{E}\right)$ and $27 / 28$ $\left(41.73^{\circ} \mathrm{N} 4.11^{\circ} \mathrm{E}\right)$. As a reference, the median winter depth profile (Median) of the same variables, and the lower (LW) and upper (UR) ranges of concentration where data are flagged " 0 " in winter are also plotted.

fore, chemolithotrophic activity in sinking particles appears to be a realistic pathway for the accumulation of ammonium in the mesopelagic zone of the Catalan Sea.

\section{Deviations from reference depth profiles}

In this section we inspect data that have failed the quality control, i.e. they have been excluded from the establishment of the reference depth profiles described above. We have identified three processes that affect the concentration of biogeochemical variables in the Catalan Sea: coastal eutrophication, DSWC and deep water formation.

High nutrient concentrations in surface coastal waters due to river discharges or anthropogenic influence can be easily identified in our dataset, though coastal conditions are poorly represented in this study: only $5.3 \%$ of the stations have a bottom depth lower than 50 $\mathrm{m}$, the lowest bottom depth being $20 \mathrm{~m}$. The Catalan coast shows a high variability in nutrient concentrations in response to the characteristics of the coast (i.e. beaches, rocky coasts and harbours), and the existence of continental or anthropogenic outflows (Flo and Camp 2005). This variability is also influenced by seasonality. For example, before the installation of a wastewater treatment plant, in summer months nutrient and Chl $a$ concentration in surface waters of the Blanes Bay reached maximum values related to the increase in population (Duarte et al. 1999, Guadayol et al. 2009). However, the present study shows that on the continental shelf the lowest nutrient concentrations are found in summer, suggesting that occasional coastal fertilization processes have local effects, and cannot be distinguished with the dataset used. Still, data outside the quality control ranges of concentration in surface waters occur mainly near the Ebre River and near large 

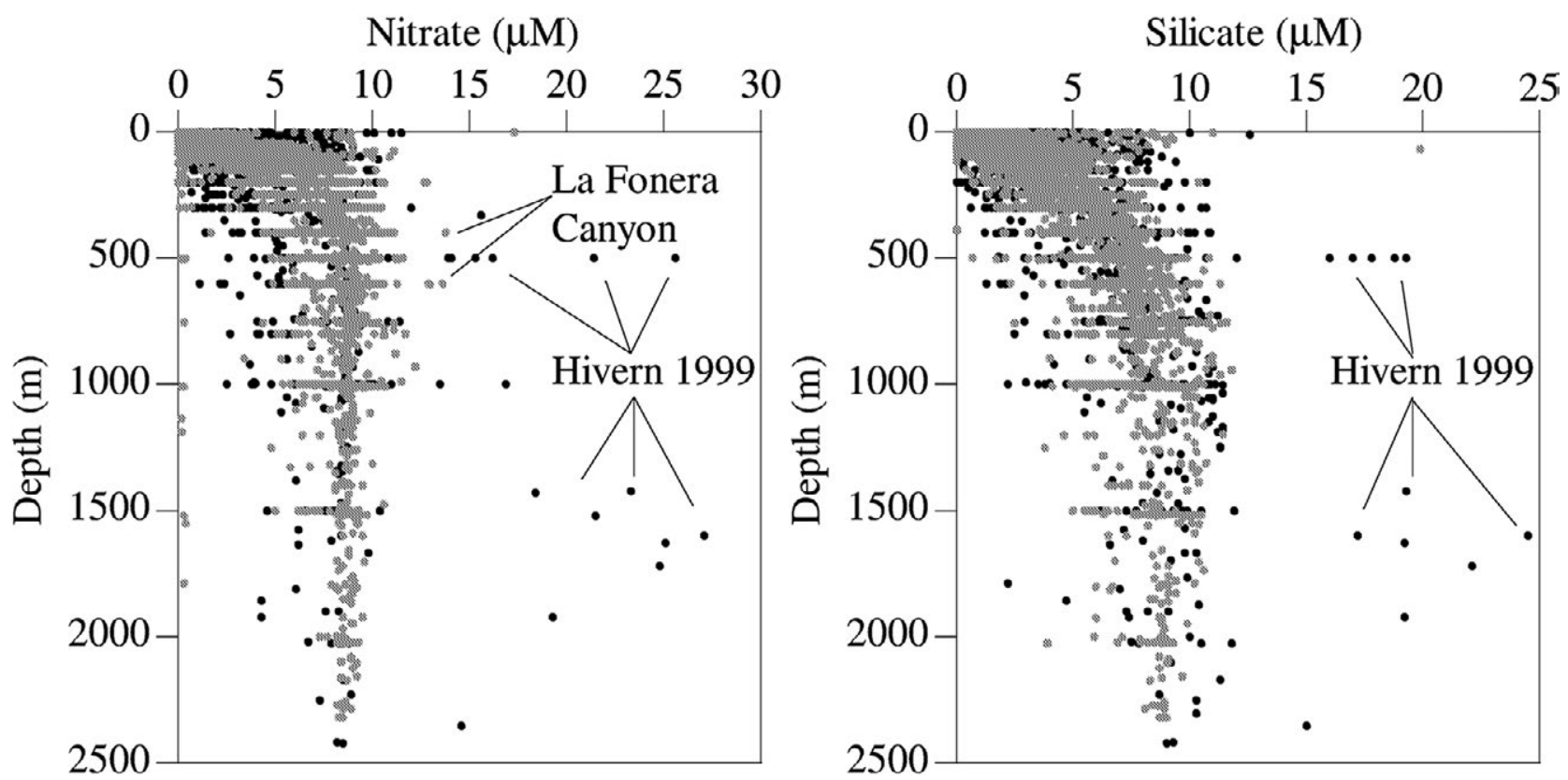

Fig. 9. - Scatter plots of nitrate and silicate vs. depth, including all the data collected. Black dots are from cruises in winter, and gray dots are from cruises between spring and autumn. High values are observed in mesopelagic and deep waters, corresponding to the Hivern cruise in 1999, a year of intense deep shelf water cascading in the Cap de Creus Canyon, as well as inside the La Fonera Canyon (south of the Cap the Creus Canyon) in 2001

cities such as Barcelona, Tarragona and Palma (see Fig. 1), indicating that these high values are related to anthropogenic activity and river discharges.

In the open sea, anomalous depth profiles are found in the northern part of the Catalan Sea in winter, and are related to WMDW formation and to DSWC. WMDW is formed in winter in the Gulf of Lion and the northern part of the Catalan Sea (MEDOC Group 1970, Salat 1983, Font et al. 1988). During WMDW formation, T, S, and density characteristics are homogeneous throughout the water column $(0-2800$ m) (Salat 1996). Nutrients, density anomaly and dissolved oxygen profiles of two stations of the cruise Hivern 2000, sampled during the process of WMDW formation, are shown in Figure 8. It can be observed that the biogeochemical depth profiles resulting from the mixing during the WMDW formation are also homogeneous throughout the water column, with concentrations equivalent to deep waters. For comparison, the median winter concentration profiles of the same variables are also plotted in Figure 8, together with the limits of the winter quality control ranges. These profiles "fail" the quality control, which is constructed on the basis of depth. However, the concentrations are in agreement with those measured in deep waters, which can be easily identified by their $\mathrm{S}$, $\theta$, and $\sigma-\mathrm{T}$ characteristics.

DSWC also occurs in winter, when cold and dry northerly winds cause heat loss and evaporation of surface Gulf of Lion shelf waters. The waters therefore become cooler and mix with off-shelf waters, becoming denser than the surrounding waters and rapidly sinking, overflowing the shelf edge and cascading downslope through submarine canyons. Depending on the resulting density, the waters can reach the bottom of the basin, or detach from the slope when they reach their equilibrium with surrounding waters (Canals et al. 2006). In the Cap de Creus Canyon (Fig. 1) four major cascading events were identified in 1980, 1988, 1999 and 2005 (Canals et al. 2009). In our dataset, we have identified relatively large $(\sim 12 \mu \mathrm{M})$ nitrate and silicate concentrations in La Fonera Canyon, and very large concentrations below $500 \mathrm{~m}$ depth in the winter of 1999 (cruise Hivern 1999), up to $41.5 \mu \mathrm{M}$ nitrate and $24.5 \mu \mathrm{M}$ silicate (Fig. 9), which are more than three times the corresponding concentrations in deep waters. The corresponding phosphate values are also high (between 0.37 and $0.71 \mu \mathrm{M}$ ), but because the range of concentration of phosphate in the Catalan Sea is narrower, they cannot be so easily identified. In shelf surface waters of the Gulf of Lion (0-5 m depth) in winter, high nutrient concentrations have been measured on several cruises (up to $41.0 \mu \mathrm{M}$ nitrate, $42.7 \mu \mathrm{M}$ silicate and $2.00 \mu \mathrm{M}$ phosphate), including years of intense cascading (Pelagolion 2 in 1986, Discovery88 and Pelagolion 3 in 1988, and Tyro in 1991). These high concentrations are related to nutrient discharges from the Rhône River (Cruzado and Velásquez 1990). We suggest that deep shelf cascading of winter surface waters, enriched in nutrients through the discharge of the Rhône River, could be the process that causes the occasional presence of high nutrients in intermediate waters in the Catalan Sea.

\section{Biogeochemical seasonality in surface waters}

Seasonal differences in the biogeochemistry of surface waters have been studied by the statistical comparison of integrated concentrations $(0-100 \mathrm{~m})$. As expected, a clear seasonality in $\mathrm{T}$ is found in sur- 
face waters (Salat 1996, Duarte et al. 1999), driving the stratification of the water column (Segura-Noguera et al. 2011). The stratification is broken by convective processes (vertical mixing) related to an increase in the wind velocity and storms in autumn and winter (Salat 1996, Send et al. 1999, Guadayol and Peters, 2006), resulting in an enrichment of surface waters. Surface $\mathrm{S}$ does not show such strong seasonality, but even so, higher values are found in autumn and winter due to wind-driven evaporation and winter mixing with deeper and saltier waters (Salat 1996), which results in a larger surface density anomaly in this season. Seasonal biogeochemical differences are not always statistically significant (Table 2). For example, phosphate concentration in winter is not statistically different from that in autumn, possibly because of its fast uptake by phytoplankton as soon as nutrients become available.

Chl $a$ concentration is higher in mixing conditions (winter) than during the rest of the year, in contrast to the most usual spring bloom (Longhurst 1988). This is possible because of the higher irradiance (around 20\%) as well as warmer temperatures ( 3 to $5^{\circ} \mathrm{C}$ higher) in the Mediterranean Sea than in the Atlantic Ocean at the same latitude (Duarte et al. 1999), as well as because deep mixing occurs during winter (e.g. Salat 1996), which result in nutrient enriched surface waters. Chl $a$ concentration decreases from winter to summer following a decrease in autotrophic organisms, both because the nutrients are being consumed (and hence the DCM moves towards deeper waters), and because grazing pressure is increased (Bahamón and Cruzado 2003).

In autumn, after the stratification is broken and the nutrient concentration increases in surface waters, the DCM is found at shallower depths, as already described (Estrada 1985a,b, Bahamón and Cruzado 2003). However its intensity, as well as that of the PNM, is smaller than in summer and spring. As a consequence, unlike nutrient concentration, integrated $\mathrm{Chl} a$ concentration is lower in autumn than in summer (Table 2). Assuming that there are no changes in irradiance compared with the summer months, the smaller DCM in autumn could partly result from a decrease in pigment concentration per cell due to photoacclimation. In addition, the lower $\% \mathrm{O}_{2}$ saturation in autumn suggests that the decrease in Chl $a$ in this season could also be related to a decrease in the abundance of autotrophic organisms. Finally, the sudden increase in the Catalan Current intensity in autumn driven by wind and storms (Astraldi and Gasparini 1992, Font et al. 1995) could result in an increase in Chl $a$ exported from the Catalan Sea. However, additional data such as particulate organic carbon and plankton composition are needed to determine whether the observed decrease in average $\mathrm{Chl} a$ concentration corresponds to a decrease in pigment cell content, a decreased in total biomass, or a change of populations with a different pigment composition.

\section{Nutrient limitation in the Catalan Sea}

The nitrate to phosphate ratio described by Redfield in deep waters ( $\mathrm{N}: \mathrm{P}=16: 1$, Redfield 1963) is typically used to determine whether a system is $\mathrm{N}$ - or P-limited.
Our N:P ratio in deep waters, calculated with values above detection limit, is larger than the Redfield ratio $(\mathrm{N}: \mathrm{P}>22)$, as is usually found in the western Mediterranean Sea (e.g. Copin-Montégut and Copin-Montégut 1983, Ribera d'Alcalà et al. 2003, Pujo-Pay et al. 2011). Similarly, in our deep waters (>1200 m) Si:N and $\mathrm{Si}: \mathrm{P}$ are similar to other deep values in the western Mediterranean Sea (Si:N=0.9-1.1, Ribera d'Alcalà et al. 2003; N:Si:P=22:19.5:1, Béthoux et al. 2002) and in the Gibraltar Strait (N:Si:P=31.5:26.5:1, Dafner et al. 2003), and the differences can be explained by the ratios being calculated at different depths. Moreover, as observed in the eastern Mediterranean Sea (Krom et al. 1991, Kress and Herut 2001), the N:P and DIN:P scatterplots show that the relationship is non-linear at low and high $\mathrm{N}$ and $\mathrm{P}$ concentrations (Fig. 7). These results suggest that $\mathrm{P}$ is the element that generally limits the production in the Catalan Sea, as found in the rest of the Mediterranean Sea (e.g. Margalef 1963, Marty et al. 2002, Krom et al. 2010). Several hypotheses explain the high N:P in the Mediterranean Sea: atmospheric deposition, unbalanced river discharges, phosphate adsorption onto Saharan dust, and nitrogen fixation by cyanophyceae and marine phanerogams (Béthoux and Copin-Montégut 1986, Krom et al. 1991, Ribera d'Alcalà et al. 2003). Indeed, in the Mediterranean Sea, $\mathrm{P}$ has long been known to limit phytoplankton production in surface waters (Margalef 1963), as has been confirmed in numerous experimental and descriptive studies (e.g. Thingstad et al. 1998, Moutin and Raimbault 2002).

However, our data also show that, in stratified surface waters above the DCM $(0-50 \mathrm{~m}), \mathrm{N}: \mathrm{P}$ and DIN:P ratios are below the Redfield ratio, while in mixed surface waters they are above it, both in the open sea and on the continental shelf. This suggests a shift from $\mathrm{N}$-limitation, in which the water column is stratified to some degree, to $\mathrm{P}$ limitation, in which the water column is mixed (Fig. 6). Using a model II regression method (our data are not normally distributed), the intercepts of both N:P and DIN:P regressions are negative and significantly different from 0 (Table 4), indicating an excess of $\mathrm{P}$ when $\mathrm{N}$ is 0 . However, if we use ordinary least squares model I (e.g. as in Kress and Herut 2001), the intercepts are positive and not significantly different from $0(\mathrm{p}>0.05)$. An examination of paired data from 0-50 m depth shows that it is more frequent to find phosphate data below detection limit when there are still measurable concentrations (i.e. above detection limit) of nitrate (59\% of the cases) or DIN (67\% of the cases), than vice versa. Low N:P ratios in surface waters, as well as median phosphate concentrations above detection limits, are unexpected results compared with the observed deep water $\mathrm{N}: \mathrm{P}$ ratio and with experimental studies about nutrient limitation in the Mediterranean Sea. Low N:P ratios could be the result of an overestimation of phosphate, as found when chemical and radiochemical methods are compared (Hudson et al. 2000), and would indicate the need to use more sensitive methods, which provide equivalent detection limits for both nutrients, to measure phosphate in surface waters of the Catalan Sea. 


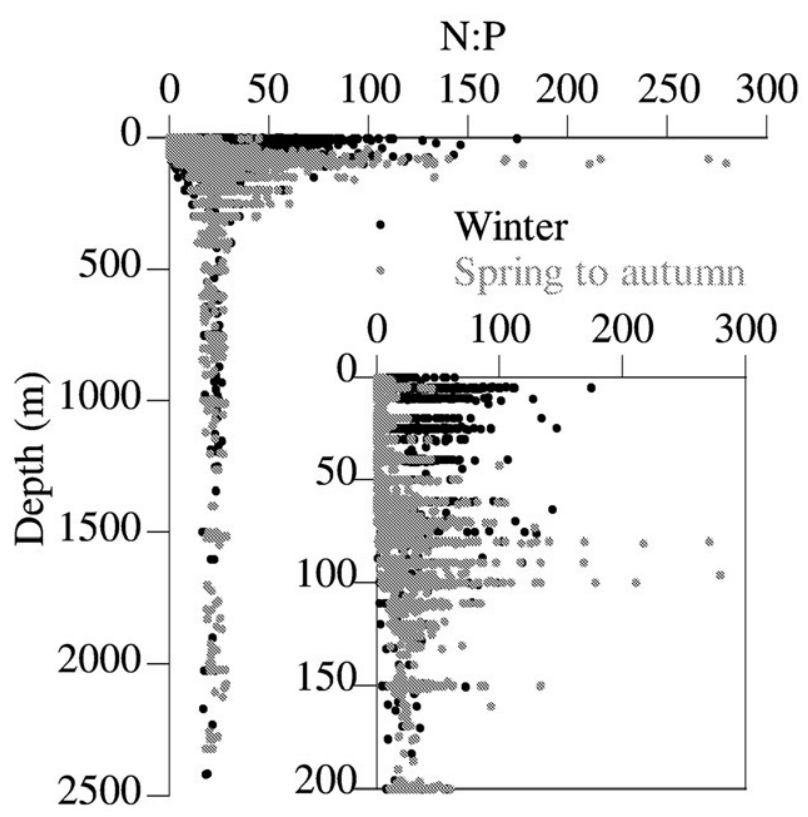

Fig. 10. - Depth profile of N:P for the Catalan Sea. Data for winter mixing are shown with black circles, and data for stratified water columns (spring-autumn) are shown with grey circles.

In addition, as observed in the western Mediterranean Sea (Raimbault and Coste 1990, Estrada 1999, Moutin and Raimbault 2002) and the Levantine Basin (e.g. Krom et al. 1991), we found a shift from Nlimitation to P limitation within the DCM, where the nitracline is found above the phosphocline (Pujo-Pay et al. 2011). The uncoupling of nutriclines causes the $\mathrm{N}: \mathrm{P}$ ratio to reach maximum values at the depth of the DCM (Fig. 10). It is suggested that the lack of phosphorus prevents the utilization of nitrogen, so nitrate (and silicate) is accumulated in the water column at a shallower depth than phosphate (Raimbault and Coste 1990).

The N:P ratio below the DCM (160-400 m depth) is around 23, which corresponds to the remineralization of particulate matter-mostly dead phytoplankton, faecal pellets and other detrital particles (Sarmiento and Gruber 2006) - from waters immediately above. Consequently, in the Catalan Sea this sinking organic material would contain more $\mathrm{N}$ than $\mathrm{P}$ relative to the Redfield ratio. The rapid turnover rate of phosphorus in the euphotic zone (Benitez-Nelson and Buesseler 1999 ) could result in a larger $\mathrm{N}: \mathrm{P}$ ratio of non-living sinking particles. Indeed, Mostajir et al. (1998) found higher than Redfield $\mathrm{N}: \mathrm{P}$ ratios in detrital matter from the Ligurian Sea $(\mathrm{N}: \mathrm{P}=32)$. In addition, some analyses of particulate matter from the NW Mediterranean Sea indicate that the $\mathrm{N}: \mathrm{P}$ ratio of the whole phytoplankton community is also larger than Redfield. Copin-Montégut and Copin-Montégut (1983) found a particulate $\mathrm{N}: \mathrm{P}$ ratio between 20 and 23 in the NW Mediterranean Sea, and suggested that the high N:P ratio in deep waters was the result of remineralization of microphytoplankton, which has an N:P 30 and higher than smaller organisms. Later studies in living cells found that the N:P ratios of cultured picoplankton cells (Synechococcus and Prochlorococcus, including one strain from the NW Mediterranean Sea) were higher than Redfield in cells grown without nutrient limitation, and up to $\mathrm{N}: \mathrm{P}=109$ under $\mathrm{P}$ limitation (Bertilsson et al. 2003). Single-cell analysis of diatoms and dinoflagellates sampled directly from the Catalan Sea also indicates that the cells are N-rich (slope N:P quota=24.6 in dinoflagellates and 38.7 in diatoms, Segura-Noguera et al. in press).

Redfield noted that the N:P obtained from nutrients in deep oceanic waters should be an average of plankton stoichiometry, which is able to adapt to oceanic nutrient availability (Redfield 1963). Several studies confirm the plasticity of plankton stoichiometry as a result of changes in the metabolic cellular machinery in response to environmental nutrient availability (e.g. Margalef 1998, Geider and LaRoche 2002), with a theoretical optimal N:P stoichiometry between 8.2 and 45.0 (Klausmeier et al. 2004). For example, diatoms, which dominate the phytoplankton community in the NW Mediterranean Sea in winter (Estrada 1999, Arin et al. 2013), are able to store nitrate, as well as phosphate, inside intracellular vacuoles, allowing them to continue growing for several generations after the nutrients are depleted (Rosen and Lowe 1984, Margalef 1998). Also, diatoms could store nitrate as pigments (Rosen and Lowe 1984), and since each chlorophyll molecule contain four atoms of $\mathrm{N}$, the resulting $\mathrm{N}: \mathrm{P}$ ratio would be higher. A larger chlorophyll concentration in diatoms compared with cultured dinoflagellates and other autotrophic organisms in natural samples has actually been suggested (e.g. Ríos et al. 1998). Another adaptation that would lead to higher cellular $\mathrm{N}: \mathrm{P}$ ratios is the preferential synthesis of $\mathrm{N}$-rich substitute lipids in response to $\mathrm{P}$ limitation, as found in the Adriatic Sea (Ivančić et al. 2012). Since the cellular stoichiometry is the result of the species-specific genetic stoichiometry and the adaptation to the nutrient availability, the coincidence in the Catalan Sea of the $\mathrm{N}: \mathrm{P}$ ratio in particulate matter and in dissolved nutrients below the euphotic zone, both of them higher than the canonical Redfield ratio, suggests an adaptation of the phytoplankton to the low P availability of the Mediterranean Sea (Klausmeier et al. 2004), and/or an evolutive selection of high N:P stoichiometry plankton cells (Kay et al. 2005). To confirm this, more measurements of the elemental composition of plankton are needed in the NW Mediterranean Sea, including other abundant groups (e.g. Primnesiophyceae), in addition to the community composition and participation in the downward flux of particulate organic matter.

\section{ACKNOWLEDGEMENTS}

This work was supported by the projects CANYONS (MAR99-1060-C03, CYCIT), CACO (REN2002-01339/MAR, MEC) and PUDEM (REN2003-06637-C02) and by an I3P pre-doctoral fellowship (CSIC, MEC) to M.S.-N. We thank Marta Estrada, Jordi Salat, Miquel Alcaraz and Laura Arin (Institut de Ciències del Mar, CSIC) for providing biogeochemical data from cruises, as well as Ana Sabatés and Albert Palanques for providing cruise opportuni- 
ties between 2001 and 2004 ("Canyons" I to IV in 2001 and "Caco" 1 to 4 in 2003 and 2004). We thank Mikhail Emelianov, Jordi Salat and Jordi Font (Institut de Ciències del Mar, CSIC) for useful guidance about the key physical oceanography aspects of the Catalan Sea. We also thank the UTM staff (CSIC) for their assistance during the above-mentioned cruises, as well as two anonymous reviewers for helpful comments that greatly improved the original manuscript submitted.

\section{REFERENCES}

Arin L., Guillén J., Segura-Noguera M., et al. 2013. Open sea hydrographic forcing of nutrient and phytoplankton dynamics in a Mediterranean coastal ecosystem. Est. Coast. Shelf Sci. 133: 116-128.

http://dx.doi.org/10.1016/j.ecss.2013.08.018

Astraldi M., Gasparini G.P. 1992. The seasonal characteristics of the circulation in the North Mediterranean basin and their relationship with the atmospheric-climatic conditions. J. Geophys. Res. 97: 9531-9540. http://dx.doi.org/10.1029/92JC00114

Bahamón N., Cruzado A. 2003. Modelling nitrogen fluxes in oligotrophic environments: NW Mediterranean and NE Atlantic. Ecol. Model. 163: 223-244. http://dx.doi.org/10.1016/S0304-3800(03)00007-3

Ballester A., Arias E., Cruzado A., et al. 1967. Estudio hidrográfico de la costa catalana, de junio de 1965 a mayo de 1967. Inv. Pesq. 31: 621-662.

Benitez-Nelson C.R., Buesseler K.O. 1999. Variability of inorganic and organic phosphorus turnover rates in the coastal ocean. Nature 398: 502-505. http://dx.doi.org/10.1038/19061

Bertilsson S., Berglund O., Karl D.M., et al. 2003. Elemental composition of marine Prochlorococcus and Synechococcus: Implications for the ecological stoichiometry of the sea. Limnol. Oceanogr. 48: 1721-1731. http://dx.doi.org/10.4319/1o.2003.48.5.1721

Béthoux J.P., Copin-Montégut G. 1986. Biological fixation of atmospheric dinitrogen in the Mediterranean Sea. Limnol. Oceanogr. 31: 1353-1358 http://dx.doi.org/10.4319/lo.1986.31.6.1353

Béthoux J.P., Morin P., Chaumery C., et al. 1998. Nutrients in the Mediterranean Sea, mass balance and statistical analysis of concentrations with respect to environmental change. Mar. Chem. 63: $155-169$. http://dx.doi.org/10.1016/S0304-4203(98)00059-0

Béthoux J.P., Morin P., Ruiz-Pino D. 2002. Temporal trends in nutrient ratios: chemical evidence of Mediterranean ecosystem changes driven by human activity. Deep-Sea Res. II 49(11): 2007-2016. http://dx.doi.org/10.1016/s0967-0645(02)00024-3

Blasco D. 1971. Acumulación de nitritos en determinados niveles marinos por acción del fitopláncton. Ph.D. Thesis, Univ. Barcelona.

Bower C., Holm-Hansen T. 1980. A salycilate-hypochlorite method for determining ammonia in seawater. Can. J. Aquat. Sci. 37: 794-798. http://dx.doi.org/10.1139/f80-106

Brzezinski M.A. 1988. Vertical distribution of ammonium in stratified oligotrophic waters. Limnol. Oceanogr. 33(5): 1176-1182. http://dx.doi.org/10.4319/1o.1988.33.5.1176

Canals M., Serra J., Riba O. 1982. Toponímia de la Mar CatalanoBalear (amb un glossari de termes genèrics). Bull. Soc. Hist. Nat. Balears 26: 169-194.

Canals M., Puig P., Durrieu de Madron X., et al. 2006. Flushing submarine canyons. Nature 444: 354-357. http://dx.doi.org/10.1038/nature05271

Canals M., Danovaro R., Heussner S., et al. 2009. Cascades in Mediterranean submarine grand canyons. Oceanography 22(1): 26-43.

http://dx.doi.org/10.5670/oceanog.2009.03

Copin-Montégut C., Copin-Montégut G. 1983. Stoichiometry of carbon, nitrogen, and phosphorus in marine particulate matter. Deep-Sea Res. 30: 31-46.

http://dx.doi.org/10.1016/0198-0149(83)90031-6

Cruzado A. 1985. Chemistry of Mediterranean Waters. In: Margalef
R. (ed.), Western Mediterranean. Pergamon Press, Oxford, pp. 126-147.

Cruzado A., Velásquez Z. 1990. Nutrients and phytoplankton in the Gulf of Lions, northwestern Mediterranean. Cont. Shelf Res. 10(9-11): 931-942.

http://dx.doi.org/10.1016/0278-4343(90)90068-W

Cruzado A., Velásquez Z., Perez M.D., et al. 2002. Nutrient fluxes from the Ebre river and subsequent across-shelf dispersion. Cont. Shelf Res. 22: 349-360. http://dx.doi.org/10.1016/S0278-4343(01)00060-7

Dafner E.V., Boscolo R., Bryden H.L. 2003. The N:Si:P molar ratio in the Strait of Gibraltar. Geophysical Research Letters 30(10): 1506 http://dx.doi.org/10.1029/2002GL016274

Duarte C.M., Agustí S., Kennedy H., et al. 1999. The Mediterranean climate as a template for Mediterranean marine ecosystems: the example of the northeast Spanish littoral. Prog. Oceanogr. 44: 245-270. http//dx doi.org/10.1016/S0079-6611(99)00028-2

Estrada M. 1985a. Deep phytoplankton and chlorophyll maxima in the Western Mediterranean. In: Moraitou-Apostolopoulou M., Kiorstis V. (Eds), Mediterranean Marine Ecosystems. Plenum Press, New York, pp. 247-277. http://dx.doi.org/10.1007/978-1-4899-2248-9_12

Estrada M. 1985b. Primary production at the deep chlorophyll maximum in the Western Mediterranean. In: Gibbs P.E. (ed.), Proc. 19th European Marine Biology Symp., Cambridge University Press, pp. 109-121.

Estrada M. 1996. Primary production in the Northwestern Mediterranean. Sci. Mar. 60(Suppl. 2): 55-64.

Estrada M. 1999. Hidrodinàmica i fitoplàncton en el Mar Català. Memorias de la Real Academia de Ciencias y Artes de Barcelona 961, vol. LVIII(6): 189-247.

Estrada M., Margalef R. 1988. Supply of nutrients to the Mediterranean photic zone along a persistent front. Oceanol. Acta 9(Spec. Issue): 133-142.

Estrada M., Marrasé C., Latasa M., et al. 1993. Variability of deep chlorophyll maximum characteristics in the northwestern Mediterranean. Mar. Ecol. Prog. Ser. 92: 289-300. http://dx.doi.org/10.3354/meps092289

Estrada M., Varela R.A., Salat J., et al. 1999. Spatio-temporal variability of the winter phytoplankton distribution across the Catalan and north Balearic fronts (NW Mediterranean). J. Plankton Res. 21: 1-20. http://dx.doi.org/10.1093/plankt/21.1.1

Falster D.S, Warton D.I, Wright I.J. 2006. SMATR: Standarised major axis tests and routines.. Available: http://www.bio.mq.edu.au/ecology/SMATR/

Fichaut M., Balopoulos E., Baudet L., et al. 1997. A common protocol to assemble a coherent database from distributed heterogeneous data sets: the MEDATLAS database experience. MAST Workshop on Project Data Management, 11-13 June, Ispra, Italy.

Flo E., Camp J. 2005. Programa de Vigilància i Control de la Qualitat Ambiental de les Aigües Litorals a Catalunya 8, Anual any 2.

Font J., Salat J., Tintoré J. 1988. Permanent features of the circulation in the Catalan Sea. Oceanol Acta 9(Spec. Issue): 51-57.

Font J., García-Ladona E., Gorriz E.G. 1995. The seasonality of mesoscale motion in the Northern Current of the western Mediterranean: several years of evidence. Oceanol. Acta 18(2): 207-219.

Geider R., La Roche J. 2002. Redfield revisited: variability of C : $\mathrm{N}$ : $\mathrm{P}$ in marine macroalgae and its biochemical basis. Eur. J. Phycol. 37: 1-17. http://dx.doi.org/10.1017/S0967026201003456

Granata T.C., Estrada M., Zika U., et al. 2004. Evidence for enhanced primary production resulting from relative vorticity induced upwelling in the Catalan current. Sci. Mar. 68(Suppl.1): 113-119.

Guadayol Ò., Peters F. 2006. Analysis of wind events in a coastal area: a tool for assessing turbulence variability for studies on plankton. Sci. Mar. 70: 9-20. http://dx.doi.org/10.3989/scimar.2006.70n19

Guadayol Ò., Marrasé C., Peters F., et al. 2009. Responses of coastal osmotrophic planktonic communities to simulated events of turbulence and nutrient load throughout a year. J. Plankton Res. 31(6): 583-600. http://dx.doi.org/10.1093/plankt/fbp019

Hammer Ø., Harper D.A.T., Ryan P.D. 2001. Paleontological Statistics Software Package for Education and Data Analysis. 
Palaeontol. Electron. 4: 9

Hansen H.P., Koroleff F. 1999. Determination of nutrients. In: Grasshoff K., Kremling K., Ehrhardt M. (eds), Methods of Seawater Analysis. Wiley-VCH, Weinheim, New York, pp. 191-228.

http://dx.doi.org/10.1002/9783527613984.ch10

Holmes R.M., Aminot A., Kérouel R., et al. 1999. A simple and precise method for measuring ammonium in marine and freshwater ecosystems. Can. J. Fish. Aquat. Sci. 56: 1801-1808. http://dx.doi.org/10.1139/f99-128

Hudson J.J., Taylor W.D., Schindler D.W. 2000. Phosphate concentration in lakes. Nature 406: 54-56. http://dx.doi.org/10.1038/35017531

Isla E., Scharek R., Latasa M. 2015. Zooplankton diel vertical migration and contribution to deep active carbon flux in the NW Mediterranean. J. Mar. Sys. 143: 86-97. http://dx.doi.org/10.1016/j.jmarsys.2014.10.017

Ivančić I., Godrijan J., Pfannkuchen M., et al. 2012. Survival mechanisms of phytoplankton in conditions of stratification-induced deprivation of orthophosphate: Northern Adriatic case study. Limnol. Oceanogr. 57(6): 1721-1731. http://dx.doi.org/10.4319/1o.2012.57.6.1721

Johnson M., Sanders R., Avgoustidi V., et al. 2007. Ammonium accumulation during a silicate-limited diatom bloom indicates the potential for ammonia emission events. Mar. Chem. 106: 63-75. http://dx.doi.org/10.1016/j.marchem.2006.09.006

Karl D.M., Knauer G.A. 1984. Vertical distribution, transport, and exchange of carbon in the Northeast Pacific Ocean: evidence for multiple zones of biological activity. Deep-Sea Res. 31: 221-243. http://dx.doi.org/10.1016/0198-0149(84)90103-1

Karl D.M., Christian J.R., Dore J.E., et al. 1996. Seasonal and interannual variability in primary production and particle flux at Station ALOHA. Deep-Sea Res. II 43(2-3): 539-568. http://dx.doi.org/10.1016/0967-0645(96)00002-1

Kay A.D., Ashton I.W., Gorokhova E., et al. 2005. Toward a stoichiometric framework for evolutionary biology. Oikos 109: 6-17. http://dx.doi.org/10.1111/j.0030-1299.2005.14048.x

Klausmeier C.A., Litchman E., Daufresne T., et al. 2004. Optimal nitrogen-to-phosphorus stoichiometry of phytoplankton. Nature 429: 171-174 http://dx.doi.org/10.1038/nature02454

Kress N., Herut B. 2001. Spatial and seasonal evolution of dissolved oxygen and nutrients in the Southern Levantine Basin (Eastern Mediterranean Sea): chemical characterization of the water masses and inferences on the N:P ratios. Deep-Sea Res. I 48: 2347-2372. http://dx.doi.org/10.1016/S0967-0637(01)00022-X

Krom M.D., Kress N., Brenner S., et al. 1991. Phosphorus limitation of primary productivity in the Eastern Mediterranean Sea. Limnol. Oceanogr. 36(6): 424-432. http://dx.doi.org/10.4319/1o.1991.36.3.0424

Krom M.D., Emeis K.-C., Van Cappellen P. 2010. Why is the Eastern Mediterranean phosphorus limited? Prog. Oceanogr. 85: 236-244. http://dx.doi.org/10.1016/j.pocean.2010.03.003

Longhurst A. 1998. Ecological Geography of the Sea. Academic Press, San Diego.

Longhurst A.R., Harrison W.G. 1988. Vertical nitrogen flux from the oceanic photic zone by diel migrant zooplankton and nekton. Deep Sea Res. A. 35 (6): 881-889. http://dx.doi.org/10.1016/0198-0149(88)90065-9

Margalef R. 1963. El ecosistema pelagico de un area costera del Mediterraneo Occidental. Memorias de la Real Academia de Ciencias y Artes de Barcelona 699, vol. XXXV (1): 1-48.

Margalef R. 1985. Western Mediterranean. Pergamon Press, Oxford.

Margalef R. 1998. Elements limitants, explotabilitat i diversitat. Homenatge a Bolós i al fósfor. Acta Bot. Barc. 45 (Homenatge a Oriol de Bolós): 633-643.

Marty J.-C., Chiavérini J., Pizay M.-D., et al. 2002. Seasonal and interannual dynamics of nutrients and phytoplankton pigments in the western Mediterranean Sea at the DYFAMED time-series station (1991-1999). Deep-Sea Res. II 49: 1965-1985. http://dx.doi.org/10.1016/S0967-0645(02)00022-X

Masó M., La Violette P.E., Tintoré J. 1990. Coastal flow modification by submarine canyons along the NE Spanish coast. Sci. Mar. 54(4): 343-348.

MEDOC Group. 1970. Observation of formation of deep water in the Mediterranean Sea. Nature 277: 1037-1040.
Millero F.J. 1996. Chemical Oceanography. CRC Press, Boca Raton, Florida.

Millot C. 1987. Circulation in the western Mediterranean sea. Oceanol. Acta 10: 149.

Minas H.J., Bonin M.C. 1988. Oxygénation physique et biologique de la Méditerranée nord-occidentale en hiver et au printemps. Oceanol. Acta 9(Spec. Issue): 123-132.

Mostajir B., Fagerbakke K.M., Heldal M., et al. 1998. Elemental composition of individual pico- and nano-sized marine detrital particles in the northwestern Mediterranean Sea. Oceanol. Acta 21(4): 589-596. http://dx.doi.org/10.1016/S0399-1784(98)80041-8

Moutin T., Raimbault P. 2002. Primary production, carbon export and nutrients availability in western and Eastern Mediterranean Sea in early summer 1996 (MINOS cruise). J. Mar. Sys. 33: 273-288.

http://dx.doi.org/10.1016/S0924-7963(02)00062-3

Olson R.J. 1981. Differential photoinhibition of marine nitrifying bacteria-A possible mechanism for the formation of the primary nitrite maximum. J. Mar. Res. 39: 227-238

Owens W.B., Millard Jr. R.C. 1985. A new algorithm for CTD oxygen calibration. J. Phys. Oceanogr. 15: 621-631.

http://dx.doi.org/10.1175/1520-0485(1985)015<0621:ANAFC $\mathrm{O}>2.0 . \mathrm{CO} ; 2$

Palanques A., Martín J., Puig P., et al. 2006. Evidence of sediment gravity flows induced by trawling in the Palamós (Fonera) submarine canyon (northwestern Mediterranean). Deep-Sea Res. I 53: $201-214$. http://dx.doi.org/10.1016/j.dsr.2005.10.003

Pascual A., Buongiorno Nardelli B., Larnicol G., et al. 2002. A case of an intense anticyclonic eddy in the Balearic Sea (western Mediterranean). J. Geophys. Res. 107(C11): 3183. http://dx.doi.org/10.1029/2001JC000913

Pujo-Pay M., Conan P., Oriol L., et al. 2011. Integrated survey of elemental stoichiometry $(\mathrm{C}, \mathrm{N}, \mathrm{P})$ from the western to eastern Mediterranean Sea. Biogeosciences 8: 883-899. http://dx.doi.org/10.5194/bg-8-883-2011

Raimbault P., Coste B. 1990. Very high values of the nitrate/phosphate ratio $(>30)$ in the subsurface layers of the Western Mediterranean Sea. Rapp. CIESMM 32 (1): 44.

Redfield A.C., Ketchum B.H., Richards F.A. 1963. The influence of organisms on the composition of sea-water. In: Hill M.N. (ed.), The Sea, Vol. 2. The Composition of Seawater. Wiley, New York.

Ribera d'Alcalà M., Civitarese G., Conversano F., et al. 2003. Nutrient ratios and fluxes hint at overlooked processes in the Mediterranean Sea. J. Geophys. Res. 108: 8106. http://dx.doi.org/10.1029/2002JC001650

Riley J.P. 1971. Micronutrient elements. In: Riley J.P., Chester R. (eds), Introduction to Marine Chemistry. Academic Press, London.

Ríos A.G., Fraga F., Pérez F.F., et al. 1998. Chemical composition of phytoplankton and particulate organic matter in the Ría de Vigo (NW Spain). Sci. Mar. 62(3): 257-271. http://dx.doi.org/10.3989/scimar.1998.62n3257

Rosen B., Lowe R. 1984. Physiological and ultrastructural responses of Cyclotella meneghiniana (Bacillariophyta) to light-intensity and nutrient limitation. J. Phycol. 20: 173-183. http://dx.doi.org/10.1111/j.0022-3646.1984.00173.x

Saino T., Otobe H., Wada E., et al. 1983. Subsurface ammonium maximum in the northern Pacific and the Bering Sea in summer. Deep-Sea Res. 30: 1157-1171. http://dx.doi.org/10.1016/0198-0149(83)90094-8

Salat J. 1983. Formation d'eau profonde près de la côte catalane au sud du $42^{\circ} \mathrm{N}$. Croisière "Caron 82": premiers resultats. Rapp. Comm. Int. Mer Médit. 28(2): 73-77.

Salat J. 1995. The interaction between the Catalan and Balearic currents in the southern Catalan Sea. Oceanol. Acta 18(2): 227-234.

Salat J. 1996. Review of hydrographic environmental factors that may influence anchovy habitats in northwestern Mediterranean. Sci. Mar. 60(Suppl. 2): 21-32.

Salat J., Cruzado A. 1981. Masses d'eau dans la Mediterranée Occidentale: Mer Catalane et eaux adjacentes. Rapp. Comm Int. Mer Médit. 27(6): 201-209.

Salat J., Font J. 1987. Water mass structure near and offshore the Catalan coast during the winters of 1982 and 1983. Ann. Geophys. B- Terr. Planet. Phys. 5: 49-54.

Salat J., Garcia M., Cruzado A., et al. 2002. Seasonal changes of water mass structure and shelf slope exchanges at the Ebre shelf (NW Mediterranean). Cont. Shelf Res. 22: 327-348. 
http://dx.doi.org/10.1016/S0278-4343(01)00031-0

Sarmiento J.L., Gruber N. 2006. Ocean Biogeochemical Dynamics. Princeton Univ. Press.

Send U., Font J., Krahmann G., et al. 1999. Recent advances in observing the physical oceanography of the western Mediterranean Sea. Prog. Oceanogr. 44: 37-64. http://dx.doi.org/10.1016/S0079-6611(99)00020-8

Segura-Noguera M., Cruzado A., Blasco D. 2011. Nutrient preservation, analysis precision and quality control of an oceanographic database (inorganic nutrients, dissolved oxygen and chlorophyl a) from the NW Mediterranean Sea. Sci. Mar. 75(2): 321-339. http://dx.doi.org/10.3989/scimar.2011.75n2321

Segura-Noguera M., Blasco D., Fortuño J.-M. In press. Taxonomic and environmental variability in the elemental composition and stoichiometry of individual dinoflagellate and diatom cells from the NW Mediterranean Sea. PLoS ONE. http://dx.doi.org/10.1371/journal.pone.0154050

Sournia A. 1973. La production primaire planctonique en Méditerranée: Essai de mise à jour. Bull. Ét. Commun. Médit. 5: 1-28.

Thingstad T.F., Zweifel U.L., Rassoulzadegan F. 1998. P limitation of heterotrophic bacteria and phytoplankton in the northwest Mediterranean. Limnol. Oceanogr. 43: 88-94. http://dx.doi.org/10.4319/1o.1998.43.1.0088

Winkler L.W. 1888. Die Bestimmung des in Wasser gelosten Sauerstoffen. Berichte der Deutschen Chemischen Gesellschaft 21: 2842-2855.

http://dx.doi.org/10.1002/cber.188802102122

Yentsch C.S., Menzel D.W. 1963. A method for the determination of phytoplankton chlorophyll and phaeophytin by fluorescence. Deep-Sea Res. 10: 221-231.

http://dx.doi.org/10.1016/0011-7471(63)90358-9

\section{SUPPLEMENTARY MATERIAL}

The following material is available through the online version of this article and at the following link:

http://www.icm.csic.es/scimar/supplm/sm04309esm.pdf

Table S1. - Detailed list of the cruises used in this study, including the year, the maximum depth sampled ( $\mathrm{z}$ max), the number of profiles (n), th ebiogeochemical variables available (shaded), and the source of the data.

Table S2. - Phosphate concentration $(\mu \mathrm{M})$ with depth and stratification of the water column in the Catalan Sea (NW Mediterranean Sea). Shown are median \pm median absolute deviation (number of data between parentheses). SL, Standard Level; SLD, Standard Level Depth (m).
Table S3. - Nitrate concentration ( $u \mathrm{M})$ with depth and stratification of the water column in the Catalan Sea (NW Mediterranean Sea). Shown are median \pm median absolute deviation (number of data between parentheses). SL, Standard Level; SLD, Standard Level Depth (m).

Table S4. - Nitrite concentration $(\mu \mathrm{M})$ with depth and stratification of the water column in the Catalan Sea (NW Mediterranean Sea). Shown are median \pm median absolute deviation (number of data between parentheses). SL, Standard Level; SLD, Standard Level Depth (m).

Table S5. - Ammonium concentration $(\mu \mathrm{M})$ with depth and stratification of the water column in the Catalan Sea (NW Mediterranean Sea). Shown are median \pm median absolute deviation (number of data between parentheses). SL, Standard Level; SLD, Standard Level Depth (m).

Table S6. - Silicate concentration $(\mu \mathrm{M})$ with depth and stratification of the water column in the Catalan Sea (NW Mediterranean Sea). Shown are median \pm median absolute deviation (number of data between parentheses). S, Standard Level; SLD, Standard Level Depth (m)

Table S7. - Chlorophyll $a$ concentration $\left(\mu \mathrm{g} \mathrm{L} \mathrm{L}^{-1}\right)$ with depth and stratification of the water column in the Catalan Sea (NW Mediterranean Sea). Shown are median \pm median absolute deviation (number of data between parentheses). SL, Standard Level; SLD, Standard Level Depth (m).

Table S8. - Dissolved oxygen concentration $(\mu \mathrm{M})$ with depth and stratification of the water column in the Catalan Sea (NW Mediterranean Sea). Shown are median \pm median absolute deviation (number of data between parentheses). SL, Standard Level; SLD, Standard Level Depth (m).

Table S9. - Salinity with depth and stratification of the water column in the Catalan Sea (NW Mediterranean Sea). Shown are average \pm standard deviation (number of data between parentheses). SL, Standard Level; SLD, Standard Level Depth (m)

Table S10. - Potential th depth and stratification of the water column in the Catalan Sea (NW Mediterranean Sea). Shown are average \pm stanemperature $\left({ }^{\circ} \mathrm{C}\right.$ ) witdard deviation (number of data between parentheses). SL, Standard Level; SLD, Standard Level Depth $(\mathrm{m})$.

Table S11. - Density anomaly $\left(\mathrm{kg} \mathrm{m}^{-3}\right)$ with depth and stratification of the water column in the Catalan Sea (NW Mediterranean Sea). Shown are average \pm standard deviation (number of data between parentheses). SL, Standard Level; SLD, Standard Level Depth (m)

Fig. S1. - Position of oceanographic stations in the Catalan Sea with phosphate, nitrate, nitrite, ammonium, silicate, dissolved oxygen and chlorophyll $a$ data. Isobaths correspond to 100, 200, 400, 1000, 2000 and $2500 \mathrm{~m}$ depth. 


\section{The biogeochemistry of nutrients, dissolved oxygen and chlorophyll $a$ in the Catalan Sea (NW Mediterranean Sea)}

Mariona Segura-Noguera, Antoni Cruzado, Dolors Blasco

Supplementary material 
S2 • M. Segura-Noguera et al.

Table S1. - Detailed list of the cruises used in this study, including the year, the maximum depth sampled (z max), the number of profiles (n), th ebiogeochemical variables available (shaded), and the source of the data

\begin{tabular}{|c|c|c|c|c|c|c|c|c|c|c|c|}
\hline Cruise & year & $\mathrm{z} \max$ & $\mathrm{n}$ & $\mathrm{PO}_{4}$ & $\mathrm{NO}_{2+3}$ & $\mathrm{NO}_{2}$ & $\mathrm{NH}_{4}$ & $\mathrm{Si}(\mathrm{OH})_{4}$ & $\mathrm{O}_{2}$ & Chl $a$ & source \\
\hline ARCHIVES & 1910 & 1000 & 4 & & & & & & & & 1 \\
\hline MUSEUM & 1930 & 1500 & 1 & & & & & & & & 1 \\
\hline MUSEUM & 1951 & 796 & 1 & & & & & & & & 1 \\
\hline NODC-1468-1 & 1951 & 1775 & 1 & & & & & & & & 1 \\
\hline 57051411 & 1957 & 1000 & 1 & & & & & & & & 1 \\
\hline NODC-322-3-ATLANT & 1961 & 2297 & 22 & & & & & & & & 1 \\
\hline s.h $11-61$ & 1961 & 1936 & 36 & & & & & & & & 1 \\
\hline NODC-0210-3-ATLANT & 1962 & 2540 & 2 & & & & & & & & 1 \\
\hline S.H $05-62$ & 1962 & 2212 & 35 & & & & & & & & 1 \\
\hline S.H $10-63$ & 1963 & 2240 & 3 & & & & & & & & 1 \\
\hline S.H 03-64 & 1964 & 289 & 3 & & & & & & & & 1 \\
\hline S.H $10-64$ & 1964 & 2141 & 17 & & & & & & & & 1 \\
\hline S.H 01-65 & 1965 & 591 & 15 & & & & & & & & 1 \\
\hline S.H 04-65 & 1965 & 1850 & 14 & & & & & & & & 1 \\
\hline S.H 03-66 & 1966 & 1940 & 4 & & & & & & & & 1 \\
\hline S.H 04-67 & 1967 & 1182 & 4 & & & & & & & & 1 \\
\hline MEDOC 1969 & 1969 & 2480 & 18 & & & & & & & & 1 \\
\hline NODC-1355-5 & 1969 & 2429 & 13 & & & & & & & & 1 \\
\hline MEDOC 1970 & 1970 & 2504 & 60 & & & & & & & & 1 \\
\hline 3131 & 1971 & 814 & 5 & & & & & & & & 1 \\
\hline 3132 & 1971 & 75 & 3 & & & & & & & & 1 \\
\hline S.H 02-71 & 1971 & 495 & 1 & & & & & & & & 1 \\
\hline S.H 04-71 & 1971 & 485 & 1 & & & & & & & & 1 \\
\hline S.H $07-71$ & 1971 & 489 & 1 & & & & & & & & 1 \\
\hline S.H 09-71 & 1971 & 535 & 1 & & & & & & & & 1 \\
\hline 3767 & 1972 & 514 & 9 & & & & & & & & 1 \\
\hline S.H & 1972 & 590 & 2 & & & & & & & & 1 \\
\hline 7224 & 1973 & 500 & 14 & & & & & & & & 1 \\
\hline CONTA 75 & 1975 & 1800 & 8 & & & & & & & & 1 \\
\hline MAHON-III & 1975 & 24 & 4 & & & & & & & & 1 \\
\hline OBM-II & 1975 & 1000 & 1 & & & & & & & & 1 \\
\hline OBM-III & 1975 & 1000 & 9 & & & & & & & & 1 \\
\hline 13 CRUISE & 1976 & 2451 & 10 & & & & & & & & 1 \\
\hline CAMBRILS-1 & 1976 & 70 & 13 & & & & & & & & 1 \\
\hline CAMBRILS-2 & 1976 & 70 & 16 & & & & & & & & 1 \\
\hline CAMBRILS-3 & 1976 & 70 & 17 & & & & & & & & 1 \\
\hline CAMBRILS-4 & 1976 & 70 & 17 & & & & & & & & 1 \\
\hline MAHON-IV & 1976 & 35 & 4 & & & & & & & & 1 \\
\hline NDCA-00039 & 1976 & 1400 & 18 & & & & & & & & 1 \\
\hline OBM-IV & 1976 & 600 & 11 & & & & & & & & 1 \\
\hline OBM-VI & 1976 & 1000 & 11 & & & & & & & & 1 \\
\hline ROMB-1 & 1978 & 40 & 4 & & & & & & & & 1 \\
\hline ROMB-2 & 1978 & 40 & 4 & & & & & & & & 1 \\
\hline ROMB-3 & 1978 & 40 & 4 & & & & & & & & 1 \\
\hline ROMB-4 & 1979 & 40 & 4 & & & & & & & & 1 \\
\hline TANIT & 1979 & 2100 & 16 & & & & & & & & 2 \\
\hline MAHON-80 & 1980 & 27 & 49 & & & & & & & & 1 \\
\hline MAHON-81 & 1981 & 27 & 51 & & & & & & & & 1 \\
\hline PEP 82 & 1982 & 1400 & 54 & & & & & & & & 3 \\
\hline ROMM-82 & 1982 & 26 & 5 & & & & & & & & 1 \\
\hline PEP 83 & 1983 & 2236 & 94 & & & & & & & & 3 \\
\hline ROMM-83 & 1983 & 25 & 13 & & & & & & & & 1 \\
\hline PEP 84 & 1984 & 2318 & 52 & & & & & & & & 3 \\
\hline PEMTA-1 & 1984 & 70 & 22 & & & & & & & & 1 \\
\hline PEMTA-2 & 1984 & 51 & 4 & & & & & & & & 1 \\
\hline BALEAR-I & 1985 & 767 & 15 & & & & & & & & 1 \\
\hline BALEAR-II & 1985 & 715 & 7 & & & & & & & & 1 \\
\hline BALEAR-III & 1985 & 628 & 20 & & & & & & & & 1 \\
\hline CARON85 & 1985 & 1606 & 20 & & & & & & & & 2 \\
\hline FRONTS-3-85 & 1985 & 1966 & 17 & & & & & & & & 4 \\
\hline FRONTS-6-85 & 1985 & 2200 & 23 & & & & & & & & 4 \\
\hline CARBAL-III & 1986 & 48 & 15 & & & & & & & & 1 \\
\hline PELAGOLION-I & 1986 & 1500 & 4 & & & & & & & & 2 \\
\hline PELAGOLION-II & 1986 & 2235 & 5 & & & & & & & & 2 \\
\hline PEP 86 & 1986 & 2331 & 39 & & & & & & & & 4 \\
\hline FRONTS-11-86 & 1986 & 2150 & 15 & & & & & & & & 4 \\
\hline PEP 87 & 1987 & 1983 & 20 & & & & & & & & 4 \\
\hline BALEAR-IV & 1987 & 875 & 23 & & & & & & & & 1 \\
\hline BALEAR-V & 1987 & 960 & 29 & & & & & & & & 1 \\
\hline BALEAR-VI & 1987 & 965 & 30 & & & & & & & & 1 \\
\hline BAHIAS-88 & 1988 & 30 & 22 & & & & & & & & 1 \\
\hline BALEAR-VII & 1988 & 960 & 23 & & & & & & & & 1 \\
\hline BALEAR-VIII & 1988 & 941 & 27 & & & & & & & & 1 \\
\hline DISCOVERY 88 & 1988 & 1354 & 2 & & & & & & & & 2 \\
\hline PELAGOLION-III & 1988 & 1500 & 3 & & & & & & & & 2 \\
\hline FRONTS 89 & 1989 & 2145 & 28 & & & & & & & & 5 \\
\hline
\end{tabular}




\begin{tabular}{|c|c|c|c|c|c|c|c|c|c|c|c|}
\hline Cruise & year & $\mathrm{z} \max$ & $\mathrm{n}$ & $\mathrm{PO}_{4}$ & $\mathrm{NO}_{2+3}$ & $\mathrm{NO}_{2}$ & $\mathrm{NH}_{4}$ & $\mathrm{Si}(\mathrm{OH})_{4}$ & $\mathrm{O}_{2}$ & Chl $a$ & source \\
\hline BAHIAS 89 & 1989 & 30 & 22 & & & & & & & & 1 \\
\hline BAHIAS-90 & 1990 & 30 & 21 & & & & & & & & 1 \\
\hline CYBELE & 1990 & 1700 & 33 & & & & & & & & 2 \\
\hline RHODIBER & 1990 & 1764 & 6 & & & & & & & & 2 \\
\hline FRONTS 90 & 1990 & 2332 & 30 & & & & & & & & 5 \\
\hline BAHIAS-91 & 1991 & 30 & 49 & & & & & & & & 1 \\
\hline IBIZA-791 & 1991 & 500 & 5 & & & & & & & & 1 \\
\hline TYRO & 1991 & 2284 & 7 & & & & & & & & 2 \\
\hline FRONTS 91 & 1991 & 2110 & 37 & & & & & & & & 5 \\
\hline FRONTS 92 & 1992 & 2174 & 27 & & & & & & & & 6 \\
\hline BAHIAS-92 & 1992 & 30 & 7 & & & & & & & & 1 \\
\hline FORMENTERA & 1993 & 3 & 2 & & & & & & & & 1 \\
\hline VARIMED 93 I & 1993 & 2214 & 60 & & & & & & & & 6 \\
\hline VARIMED 93 II & 1993 & 2048 & 21 & & & & & & & & 6 \\
\hline VARIMED 93 III & 1993 & 1860 & 41 & & & & & & & & 6 \\
\hline RABDAL-94 & 1994 & 200 & 31 & & & & & & & & 1 \\
\hline EUROMODEL-JUL95 & 1995 & 2028 & 5 & & & & & & & & 1 \\
\hline RABDAL-95 & 1995 & 200 & 36 & & & & & & & & 1 \\
\hline MESO 95 & 1995 & 2208 & 181 & & & & & & & & 2 \\
\hline VARIMED 95 & 1995 & 2120 & 32 & & & & & & & & 7 \\
\hline CNL APR96 & 1996 & 200 & 15 & & & & & & & & 1 \\
\hline CNL JUL96 & 1996 & 200 & 15 & & & & & & & & 1 \\
\hline CNL MAR96 & 1996 & 200 & 15 & & & & & & & & 1 \\
\hline CNL MAY96 & 1996 & 200 & 15 & & & & & & & & 1 \\
\hline CNL1 JUN96 & 1996 & 200 & 15 & & & & & & & & 1 \\
\hline FANS 1 & 1996 & 1152 & 54 & & & & & & & & 2 \\
\hline FANS 1 & 1996 & 1152 & 54 & & & & & & & & 2 \\
\hline FANS 2 & 1997 & 1303 & 107 & & & & & & & & 2 \\
\hline FANS 3 & 1997 & 1200 & 110 & & & & & & & & 2 \\
\hline CNL APR97 & 1997 & 200 & 15 & & & & & & & & 1 \\
\hline CNL AUG97 & 1997 & 200 & 15 & & & & & & & & 1 \\
\hline CNL JAN97 & 1997 & 200 & 14 & & & & & & & & 1 \\
\hline CNL JUN97 & 1997 & 200 & 8 & & & & & & & & 1 \\
\hline CNL MAY97 & 1997 & 200 & 11 & & & & & & & & 1 \\
\hline CNL OCT97 & 1997 & 200 & 15 & & & & & & & & 1 \\
\hline CNL JAN98 & 1998 & 200 & 12 & & & & & & & & 1 \\
\hline CNL JUN98 & 1998 & 200 & 36 & & & & & & & & 1 \\
\hline HIVERN 99 & 1999 & 2389 & 47 & & & & & & & & 7 \\
\hline HIVERN 2000 & 2000 & 2367 & 50 & & & & & & & & 7 \\
\hline CANYONS I & 2001 & 1954 & 32 & & & & & & & & 8 \\
\hline CANYONS II & 2001 & 1922 & 44 & & & & & & & & 8 \\
\hline CANYONS III & 2001 & 1955 & 24 & & & & & & & & 8 \\
\hline CANYONS IV & 2001 & 1081 & 14 & & & & & & & & 8 \\
\hline CACO 1 & 2003 & 1331 & 67 & & & & & & & & 8 \\
\hline $\mathrm{CACO} 2$ & 2003 & 1328 & 65 & & & & & & & & 8 \\
\hline $\mathrm{CACO} 3$ & 2004 & 1326 & 66 & & & & & & & & 8 \\
\hline $\mathrm{CACO} 4$ & 2004 & 1322 & 66 & & & & & & & & 8 \\
\hline
\end{tabular}

Source of the data:

1. Data extracted from the MEDAR and MEDATLAS databases between 0 and $4.5^{\circ} \mathrm{E}, 38.7$ and $42.5^{\circ} \mathrm{N}$ (Mater Group. 2001. MTPII-MATER 1996-1999. Mass transfer and ecosystem response database, IFREMER Edition; Medar Group. 2002. MEDATLAS/2002 database. Mediterranean and Black Sea database of temperature salinity and bio-chemical parameters. Climatological Atlas. IFREMER Edition).

2. Dr. A. Cruzado, Centre for Advanced Studies of Blanes (CEAB-CSIC), Catalonia.

3. Grup PEPS. 1986. Datos oceanográficos básicos de las campañas PEP-82, PEP-83 y PEP-84 en el Mar Catalán. Datos Informativos, Institute of Marine Sciences (ICM-CSIC), 19: 1-100.

4. Masó M. and Grup PEPS. 1988. Datos oceanográficos básicos de las campañas Fronts-3-85, Fronts-6-85, PEP-86, Fronts-11-86 y PEP-87 en el Mar Catalán. Datos informativos, Institute of Marine Sciences (ICM-CSIC), 24: 1-83.

5. Varela R. and Group FRONTS. 1991. Datos Oceanográficos Básicos de las Campañas FRONTS 1989, FRONTS 1990 y FRONTS 1991 en el Mar Catalán. Datos informativos, Institute of Marine Sciences (ICM-CSIC), 26: 1-71.

6. Masó M. and Grup Varimed. 1995. Datos Oceanográficos Básicos de las Campañas «FRONTS 1992» (octubre-noviembre 1992) y «VARIABILIDAD DE MESOESCALA EN EL MEDITERRANEO OCCIDENTAL» (June 1993). Datos informativos, Institute of Marine Sciences (ICM-CSIC), 27: 1-117.

7. Dr. M. Estrada, Institute of Marine Sciences (ICM-CSIC), Barcelona, Catalonia.

8. This study. 
Table S2. - Phosphate concentration ( $\mu \mathrm{M})$ with depth and stratification of the water column in the Catalan Sea (NW Mediterranean Sea). Shown are median \pm median absolute deviation (number of data between parentheses). SL, Standard Level; SLD, Standard Level Depth (m).

\begin{tabular}{|c|c|c|c|c|c|}
\hline $\begin{array}{l}\text { Strat. Inde } \\
\text { Season } \\
\text { SL } \\
\end{array}$ & SLD & $\begin{array}{c}1 \\
\text { Winter }\end{array}$ & $\begin{array}{c}2 \\
\text { Spring } \\
\text { Open Sea (statio }\end{array}$ & $\begin{array}{c}3 \\
\text { Summer } \\
\text { depth }>200 \mathrm{~m})\end{array}$ & $\begin{array}{c}4 \\
\text { Autumn }\end{array}$ \\
\hline 1 & 0 & $0.14 \pm 0.07(66)$ & $0.12 \pm 0.07(162)$ & $0.04 \pm 0.04(48)$ & $0.00 \pm 0.00(29)$ \\
\hline 2 & 5 & $0.08 \pm 0.05(161)$ & $0.05 \pm 0.04$ & $0.03 \pm 0.03(105)$ & $0.06 \pm 0.06(94)$ \\
\hline 3 & 10 & $0.11 \pm 0.06(67)$ & $0.08 \pm 0.07(181)$ & $0.04 \pm 0.04$ & $0.14 \pm 0.08(59)$ \\
\hline 4 & 20 & $0.11 \pm 0.07(143)$ & $0.05 \pm 0.04$ & $0.04 \pm 0.04(78)$ & $0.05 \pm 0.05(59)$ \\
\hline 5 & 30 & $0.07 \pm 0.04$ & $0.08 \pm 0.06(208)$ & $0.03 \pm 0.03(77)$ & $0.11 \pm 0.08(76)$ \\
\hline 6 & 40 & $0.11 \pm 0.05(173)$ & $0.06 \pm 0.04(322)$ & $0.05 \pm 0.03(69)$ & $0.07 \pm 0.06(92)$ \\
\hline 7 & 50 & $0.13 \pm 0.06(55)$ & $0.09 \pm 0.07(241)$ & $0.03 \pm 0.03(78)$ & $0.14 \pm 0.08(57)$ \\
\hline 8 & 60 & $0.10 \pm 0.05$ & $0.07 \pm 0.04(239)$ & $0.03 \pm 0.03(89)$ & $0.08 \pm 0.06(67)$ \\
\hline 9 & 80 & $0.14 \pm 0.06(204)$ & $0.11 \pm 0.06(498)$ & $0.06 \pm 0.04(177)$ & $0.14 \pm 0.08$ \\
\hline 10 & 100 & $0.16 \pm 0.07(207)$ & $0.16 \pm 0.07(447)$ & $0.12 \pm 0.06(152)$ & $0.18 \pm 0.08$ \\
\hline 11 & 120 & $0.23 \pm 0.05(44)$ & $0.22 \pm 0.05$ & $0.18 \pm 0.04$ & $0.26 \pm 0.06(53)$ \\
\hline 12 & 160 & $0.22 \pm 0.09(105)$ & $0.23 \pm 0.07(200)$ & $0.23 \pm 0.07(79)$ & $0.26 \pm 0.08(55)$ \\
\hline 13 & 200 & $0.25 \pm 0.08$ & $0.29 \pm 0.07(256)$ & $0.23 \pm 0.05(66)$ & $0.34 \pm 0.07(91)$ \\
\hline 14 & 250 & $0.25 \pm 0.08(58)$ & $0.32 \pm 0.06(99)$ & $0.29 \pm 0.05(40)$ & $0.32 \pm 0.08$ \\
\hline 15 & 300 & $0.32 \pm 0.08(106)$ & $0.36 \pm 0.07(144)$ & $0.32 \pm 0.04(47)$ & $0.35 \pm 0.06(35)$ \\
\hline 16 & 400 & $0.37 \pm 0.04$ & $0.41 \pm 0.05(163)$ & $0.38 \pm 0.03$ & $0.41 \pm 0.04(57)$ \\
\hline 17 & 500 & $0.38 \pm 0.04(83)$ & $0.44 \pm 0.04(74)$ & $0.40 \pm 0.03(28)$ & $0.38 \pm 0.05(19)$ \\
\hline 18 & 600 & $0.41 \pm 0.05(43)$ & $0.43 \pm 0.03(95)$ & $0.39 \pm 0.03$ & $0.42 \pm 0.05$ \\
\hline 19 & 800 & $0.40 \pm 0.05(58)$ & $0.40 \pm 0.04(79)$ & $0.41 \pm 0.03(31)$ & $0.43 \pm 0.04(37)$ \\
\hline 20 & 1000 & $0.40 \pm 0.05(56)$ & $0.40 \pm 0.04$ & $0.39 \pm 0.03$ & $0.43 \pm 0.03$ \\
\hline 21 & 1200 & $0.36 \pm 0.01(17)$ & $0.40 \pm 0.04(9)$ & $0.34 \pm 0.02(2)$ & $0.44 \pm 0.02(6)$ \\
\hline 22 & 1400 & $0.41 \pm 0.04(6)$ & $0.39 \pm 0.01(5)$ & & $0.44 \pm 0.02$ \\
\hline 23 & 1600 & $0.44 \pm 0.05(20)$ & $0.37 \pm 0.03(22)$ & & $0.40 \pm 0.03$ \\
\hline 24 & 1800 & $0.39 \pm 0.05(7)$ & $0.38 \pm 0.04(5)$ & & $0.40 \pm 0.00(8)$ \\
\hline 25 & 2000 & $0.42 \pm 0.05$ & $0.36 \pm 0.04$ & & $0.41 \pm 0.01$ \\
\hline 26 & 2500 & $0.42 \pm 0.03(11)$ & & & $0.39 \pm 0.02(11)$ \\
\hline$\underline{\text { SL }}$ & SLD & \multicolumn{4}{|c|}{ Continental Shelf (station bottom depth $\leq 200 \mathrm{~m}$ ) } \\
\hline 1 & 0 & $0.17 \pm 0.05(65)$ & $0.09 \pm 0.08(84)$ & $0.05 \pm 0.05(21)$ & $0.17 \pm 0.09(71)$ \\
\hline 2 & 5 & $0.07 \pm 0.04(129)$ & $0.05 \pm 0.03$ & $0.05 \pm 0.01$ & $0.07 \pm 0.06(170)$ \\
\hline 3 & 10 & $0.07 \pm 0.04(127)$ & $0.08 \pm 0.06(123)$ & $0.09 \pm 0.07(19)$ & $0.16 \pm 0.10(71)$ \\
\hline 4 & 20 & $0.11 \pm 0.06(82)$ & $0.05 \pm 0.03(186)$ & $0.05 \pm 0.02(89)$ & $0.06 \pm 0.06(108)$ \\
\hline 5 & 30 & $0.08 \pm 0.04(127)$ & $0.07 \pm 0.05(116)$ & $0.07 \pm 0.05(37)$ & $0.09 \pm 0.07(101)$ \\
\hline 6 & 40 & $0.09 \pm 0.04$ & $0.05 \pm 0.02(157)$ & $0.06 \pm 0.02(73)$ & $0.06 \pm 0.03(95)$ \\
\hline 7 & 50 & $0.13 \pm 0.06(27)$ & $0.07 \pm 0.04(74)$ & $0.07 \pm 0.04$ & $0.13 \pm 0.06(41)$ \\
\hline 8 & 60 & $0.10 \pm 0.03(85)$ & $0.06 \pm 0.02(110)$ & $0.07 \pm 0.02(48)$ & $0.08 \pm 0.03(82)$ \\
\hline 9 & 80 & $0.10 \pm 0.04(84)$ & $0.08 \pm 0.03(150)$ & $0.08 \pm 0.03(69)$ & $0.10 \pm 0.05(75)$ \\
\hline 10 & 100 & $0.10 \pm 0.04(43)$ & $0.09 \pm 0.03(86)$ & $0.11 \pm 0.02(30)$ & $0.15 \pm 0.06(42)$ \\
\hline 11 & 120 & $0.11 \pm 0.05(20)$ & $0.12 \pm 0.04(19)$ & $0.10 \pm 0.02(8)$ & $0.22 \pm 0.07(9)$ \\
\hline 12 & 160 & $0.11 \pm 0.06(11)$ & $0.12 \pm 0.04(29)$ & $0.14 \pm 0.03(8)$ & $0.16 \pm 0.04(12)$ \\
\hline 13 & 200 & $0.11 \pm 0.04$ & $0.21 \pm 0.08(2)$ & & $0.26 \pm 0.14(2)$ \\
\hline
\end{tabular}

Table S3. - Nitrate concentration ( $\mu \mathrm{M})$ with depth and stratification of the water column in the Catalan Sea (NW Mediterranean Sea). Shown are median \pm median absolute deviation (number of data between parentheses). SL, Standard Level; SLD, Standard Level Depth (m).

\begin{tabular}{|c|c|c|c|c|c|}
\hline $\begin{array}{l}\text { Strat. Index } \\
\text { Season } \\
\text { SL }\end{array}$ & SLD & $\begin{array}{c}1 \\
\text { Winter }\end{array}$ & $\begin{array}{c}2 \\
\text { Spring } \\
\text { Open Sea (statio }\end{array}$ & $\begin{array}{c}3 \\
\text { Summer } \\
\text { depth }>200 \mathrm{~m})\end{array}$ & $\begin{array}{c}4 \\
\text { Autumn }\end{array}$ \\
\hline $\begin{array}{l}1 \\
2 \\
3 \\
4 \\
5 \\
6 \\
7 \\
8 \\
9 \\
10 \\
11 \\
12 \\
13 \\
14 \\
15 \\
16 \\
17 \\
18 \\
19 \\
20 \\
21 \\
22 \\
23 \\
24 \\
25 \\
26 \\
\end{array}$ & $\begin{array}{l}0 \\
5 \\
10 \\
20 \\
30 \\
40 \\
50 \\
60 \\
80 \\
100 \\
120 \\
160 \\
200 \\
250 \\
300 \\
400 \\
500 \\
600 \\
800 \\
1000 \\
1200 \\
1400 \\
1600 \\
1800 \\
2000 \\
2500 \\
\end{array}$ & $\begin{array}{c}0.50 \pm 0.38(52) \\
1.06 \pm 0.54(129) \\
0.76 \pm 0.52(61) \\
0.80 \pm 0.47(122) \\
1.49 \pm 0.63(91) \\
1.64 \pm 0.83(162) \\
1.26 \pm 0.47(46) \\
2.36 \pm 0.79(139) \\
2.45 \pm 0.90(185) \\
2.88 \pm 1.00(176) \\
2.63 \pm 0.94(23) \\
3.86 \pm 0.93(81) \\
4.59 \pm 0.89(93) \\
5.05 \pm 0.61(29) \\
7.16 \pm 1.19(82) \\
8.31 \pm 0.37(91) \\
8.66 \pm 0.15(42) \\
8.60 \pm 0.13(15) \\
8.77 \pm 0.12(31) \\
8.56 \pm 0.09(33) \\
8.57 \pm 0.08(12) \\
8.40 \pm 0.11(5) \\
8.45 \pm 0.12(10) \\
8.34 \pm 0.14(5) \\
8.53 \pm 0.16(4)\end{array}$ & $\begin{array}{l}0.12 \pm 0.10(152) \\
0.12 \pm 0.08(368) \\
0.08 \pm 0.07(260) \\
0.11 \pm 0.09(432) \\
0.14 \pm 0.11(367) \\
0.16 \pm 0.11(429) \\
0.30 \pm 0.24(352) \\
0.83 \pm 0.68(416) \\
2.65 \pm 1.52(883) \\
4.04 \pm 1.20(725) \\
5.18 \pm 1.11(285) \\
5.69 \pm 1.20(278) \\
6.47 \pm 1.08(415) \\
7.16 \pm 0.75(130) \\
7.91 \pm 0.64(267) \\
8.49 \pm 0.50(242) \\
8.84 \pm 0.24(183) \\
8.83 \pm 0.19(117) \\
8.83 \pm 0.19(143) \\
8.78 \pm 0.23(109) \\
8.70 \pm 0.30(23) \\
8.60 \pm 0.20(21) \\
8.90 \pm 0.27(42) \\
8.88 \pm 0.08(12) \\
8.89 \pm 0.17(22) \\
8.44 \pm 0.20(5)\end{array}$ & $\begin{array}{l}0.05 \pm 0.05(38) \\
0.07 \pm 0.06(95) \\
0.05 \pm 0.04(34) \\
0.06 \pm 0.06(67) \\
0.04 \pm 0.04(66) \\
0.08 \pm 0.06(60) \\
0.05 \pm 0.05(68) \\
0.10 \pm 0.07(95) \\
1.22 \pm 1.01(179) \\
3.49 \pm 1.17(148) \\
4.76 \pm 0.99(36) \\
5.60 \pm 0.92(61) \\
5.19 \pm 0.89(49) \\
7.15 \pm 0.83(21) \\
6.88 \pm 0.95(33) \\
7.81 \pm 0.49(22) \\
\\
8.40 \pm 0.00(3) \\
8.21 \pm 0.08(6) \\
8.07 \pm 0.00(2)\end{array}$ & $\begin{array}{c}0.35 \pm 0.10(21) \\
0.16 \pm 0.06(67) \\
0.21 \pm 0.13(48) \\
0.20 \pm 0.06(44) \\
0.17 \pm 0.11(64) \\
0.21 \pm 0.11(80) \\
0.36 \pm 0.18(48) \\
0.45 \pm 0.27(86) \\
1.71 \pm 1.17(143) \\
3.23 \pm 1.22(103) \\
5.61 \pm 0.97(41) \\
5.05 \pm 0.95(43) \\
6.72 \pm 1.02(83) \\
7.71 \pm 0.26(11) \\
8.22 \pm 0.38(24) \\
8.53 \pm 0.40(50) \\
8.82 \pm 0.21(18) \\
8.59 \pm 0.27(11) \\
8.64 \pm 0.12(24) \\
8.78 \pm 0.07(20) \\
8.69 \pm 0.00(1) \\
8.45 \pm 0.06(4) \\
8.58 \pm 0.03(7) \\
8.52 \pm 0.07(8) \\
8.45 \pm 0.08(11)\end{array}$ \\
\hline$\underline{\mathrm{SL}}$ & SLD & \multicolumn{4}{|c|}{ Continental Shelf (station bottom depth $\leq 200 \mathrm{~m}$ ) } \\
\hline $\begin{array}{l}1 \\
2 \\
3 \\
4 \\
5 \\
6 \\
7 \\
8 \\
9 \\
10 \\
11 \\
12 \\
13\end{array}$ & $\begin{array}{c}0 \\
5 \\
10 \\
20 \\
30 \\
40 \\
50 \\
60 \\
80 \\
100 \\
120 \\
160 \\
200\end{array}$ & $\begin{array}{c}0.70 \pm 0.28(12) \\
1.73 \pm 0.64(93) \\
1.72 \pm 0.51(92) \\
1.21 \pm 0.58(43) \\
2.23 \pm 0.64(102) \\
2.08 \pm 0.55(112) \\
2.25 \pm 1.02(14) \\
2.49 \pm 0.43(96) \\
2.52 \pm 0.49(79) \\
2.62 \pm 0.71(40) \\
2.27 \pm 0.54(18) \\
2.45 \pm 0.49(10) \\
2.37 \pm 0.43(6)\end{array}$ & $\begin{array}{c}0.15 \pm 0.12(44) \\
0.18 \pm 0.10(257) \\
0.18 \pm 0.08(169) \\
0.16 \pm 0.09(204) \\
0.15 \pm 0.08(163) \\
0.18 \pm 0.10(236) \\
0.42 \pm 0.30(130) \\
1.08 \pm 0.87(213) \\
2.19 \pm 0.95(258) \\
3.07 \pm 0.67(164) \\
3.46 \pm 0.47(45) \\
4.14 \pm 0.41(36) \\
3.74 \pm 0.02(3)\end{array}$ & $\begin{array}{c}0.05 \pm 0.04(5) \\
0.13 \pm 0.07(75) \\
0.02 \pm 0.01(7) \\
0.11 \pm 0.05(75) \\
0.13 \pm 0.06(23) \\
0.14 \pm 0.08(58) \\
0.16 \pm 0.13(13) \\
0.50 \pm 0.41(49) \\
2.27 \pm 0.80(61) \\
2.90 \pm 0.53(33) \\
2.87 \pm 0.28(11) \\
3.70 \pm 0.09(8)\end{array}$ & $\begin{array}{c}0.20 \pm 0.11(2) \\
0.17 \pm 0.06(84) \\
0.32 \pm 0.22(7) \\
0.19 \pm 0.04(44) \\
0.10 \pm 0.04(40) \\
0.22 \pm 0.12(71) \\
0.41 \pm 0.21(11) \\
0.63 \pm 0.34(74) \\
1.25 \pm 0.57(62) \\
2.64 \pm 1.09(38) \\
3.74 \pm 0.61(8) \\
3.41 \pm 0.35(11) \\
7.03(1)\end{array}$ \\
\hline
\end{tabular}


Table S4. - Nitrite concentration ( $\mu \mathrm{M})$ with depth and stratification of the water column in the Catalan Sea (NW Mediterranean Sea). Shown are median \pm median absolute deviation (number of data between parentheses). SL, Standard Level; SLD, Standard Level Depth (m).

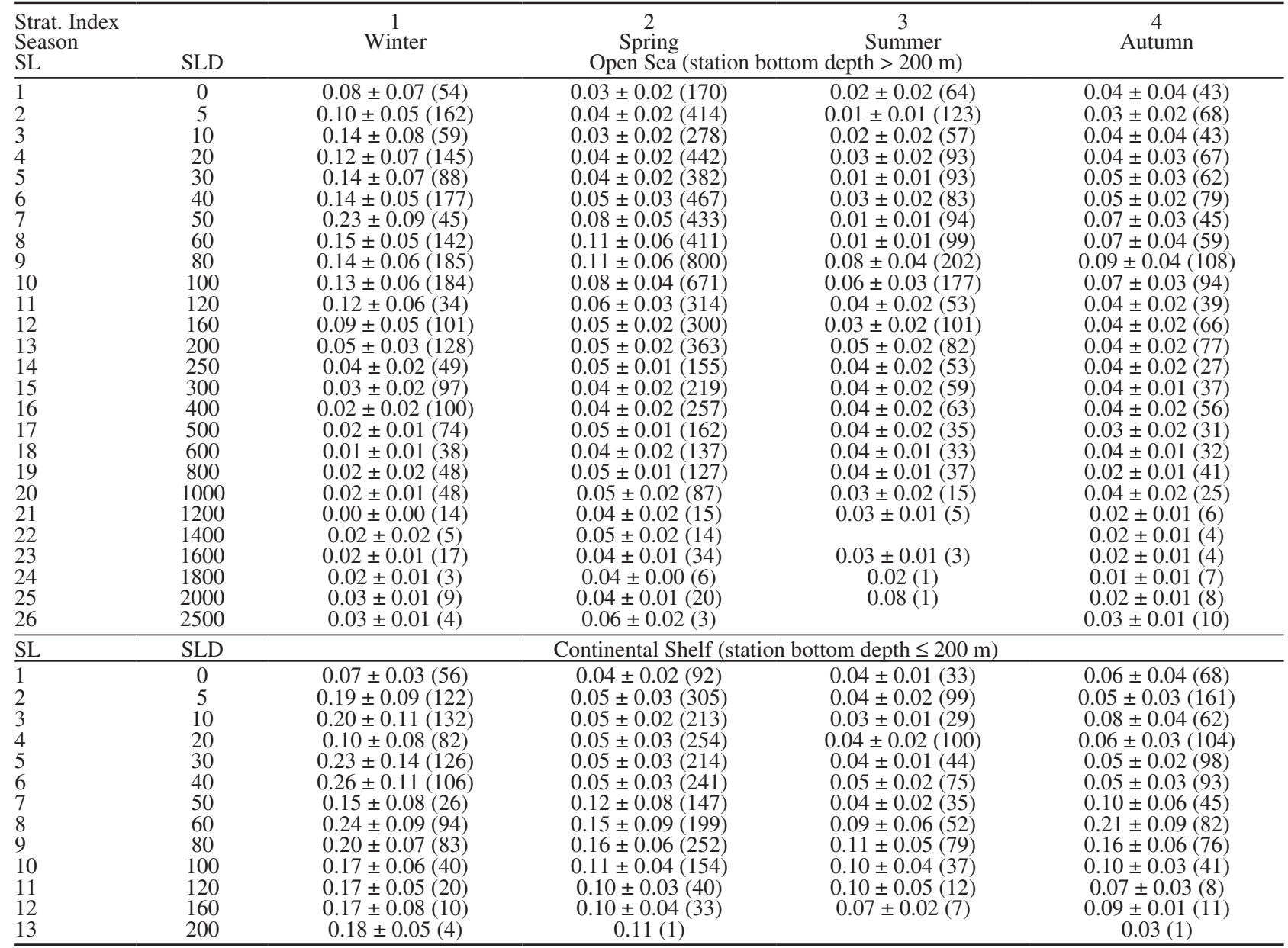

Table S5. - Ammonium concentration ( $(\mathrm{M})$ with depth and stratification of the water column in the Catalan Sea (NW Mediterranean Sea). Shown are median \pm median absolute deviation (number of data between parentheses). SL, Standard Level; SLD, Standard Level Depth (m).

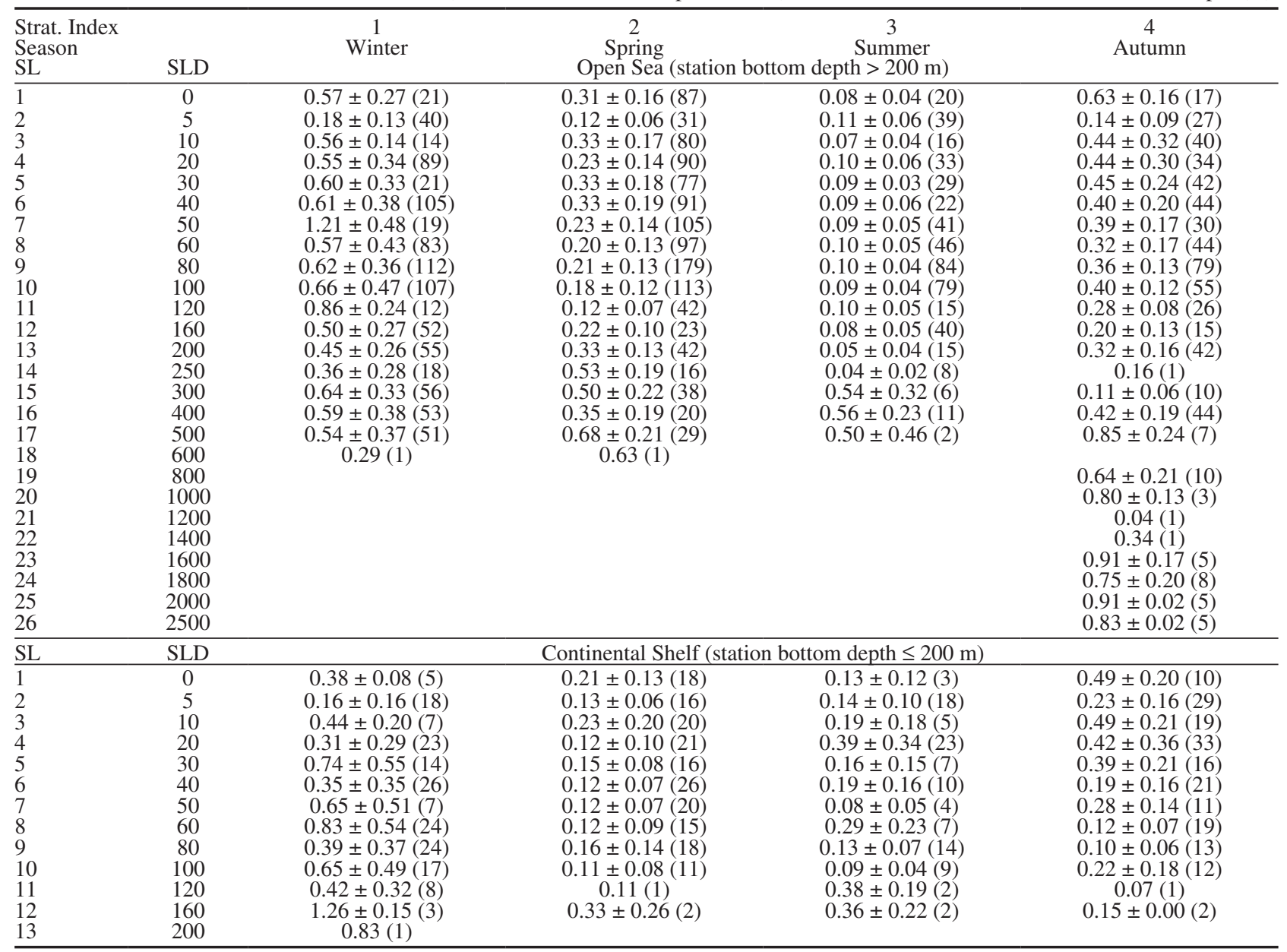


Table S6. - Silicate concentration $(\mu \mathrm{M})$ with depth and stratification of the water column in the Catalan Sea (NW Mediterranean Sea). Shown are median \pm median absolute deviation (number of data between parentheses). S, Standard Level; SLD, Standard Level Depth (m).

\begin{tabular}{|c|c|c|c|c|c|}
\hline \multicolumn{2}{|c|}{$\begin{array}{l}\text { Strat. Index } \\
\text { Season }\end{array}$} & $\stackrel{1}{\text { Winter }}$ & $\begin{array}{c}2 \\
\text { Spring } \\
\text { Open Sea (statio }\end{array}$ & $\begin{array}{c}3 \\
\text { Summer } \\
\text { depth }>200 \mathrm{~m})\end{array}$ & $\begin{array}{c}4 \\
\text { Autumn }\end{array}$ \\
\hline 1 & 0 & $1.74 \pm 0.60(73)$ & $0.81 \pm 0.46(215)$ & $0.43 \pm 0.20(69)$ & $0.50 \pm 0.28(46)$ \\
\hline 2 & 5 & $1.86 \pm 0.99(164)$ & $0.77 \pm 0.43(438)$ & $0.54 \pm 0.23(125)$ & $0.66 \pm 0.38$ \\
\hline 3 & 10 & $1.78 \pm 0.62(79)$ & $0.84 \pm 0.38$ & $0.50 \pm 0.18(62)$ & $0.27 \pm 0.27(75)$ \\
\hline 4 & 20 & $1.62 \pm 0.50(155)$ & $0.87 \pm 0.43(498)$ & $0.51 \pm 0.20(98)$ & $0.74 \pm 0.19(73)$ \\
\hline 5 & 30 & $2.59 \pm 0.85(115)$ & $1.04 \pm 0.39$ & $0.76 \pm 0.33(97)$ & $0.54 \pm 0.28$ \\
\hline 6 & 40 & $2.37 \pm 0.96(196)$ & $1.13 \pm 0.44(515)$ & $0.60 \pm 0.23(89)$ & $0.83 \pm 0.21(109)$ \\
\hline 7 & 50 & $1.92 \pm 0.55(65)$ & $1.32 \pm 0.48(489)$ & $1.08 \pm 0.55(99)$ & $0.90 \pm 0.36(75)$ \\
\hline 8 & 60 & $2.95 \pm 0.85(147)$ & $1.61 \pm 0.64(472)$ & $1.27 \pm 0.64(98)$ & $1.17 \pm 0.35(90)$ \\
\hline 9 & 80 & $2.55 \pm 1.03(222)$ & $2.05 \pm 0.62(948)$ & $1.49 \pm 0.73(207)$ & $1.78 \pm 0.53(167)$ \\
\hline 10 & 100 & $2.87 \pm 1.03(213)$ & $2.64 \pm 0.64(782)$ & $2.30 \pm 0.60(180)$ & $2.46 \pm 0.53(127)$ \\
\hline 11 & 120 & $2.54 \pm 0.58(45)$ & $3.01 \pm 0.69(356)$ & $2.90 \pm 0.55(51)$ & $2.94 \pm 0.52(63)$ \\
\hline 12 & 160 & $3.22 \pm 0.71(95)$ & $3.36 \pm 0.63(334)$ & $3.27 \pm 0.67(102)$ & $3.52 \pm 0.75(70)$ \\
\hline 13 & 200 & $4.17 \pm 0.62(100)$ & $4.09 \pm 0.70(453)$ & $3.33 \pm 0.66(82)$ & $3.90 \pm 0.82(100)$ \\
\hline 14 & 250 & $4.68 \pm 0.56(47)$ & $4.92 \pm 0.57(173)$ & $4.20 \pm 0.66(52)$ & $4.73 \pm 0.66(28)$ \\
\hline 15 & 300 & $5.74 \pm 0.70(77)$ & $5.79 \pm 0.53(276)$ & $5.37 \pm 0.53(48)$ & $6.19 \pm 0.55(27)$ \\
\hline 16 & 400 & $6.94 \pm 0.84(104)$ & $6.71 \pm 0.52(314)$ & $6.20 \pm 0.53(60)$ & $6.42 \pm 0.72(78)$ \\
\hline 17 & 500 & $7.38 \pm 0.88(77)$ & $7.56 \pm 0.63(262)$ & $6.96 \pm 0.38(27)$ & $7.69 \pm 0.53(34)$ \\
\hline 18 & 600 & $7.03 \pm 0.78$ & $7.60 \pm 0.34(171)$ & $7.23 \pm 0.55(34)$ & $7.58 \pm 0.69(36)$ \\
\hline 19 & 800 & $8.00 \pm 0.36(31)$ & $7.95 \pm 0.49(167)$ & $7.89 \pm 0.44(32)$ & $8.37 \pm 0.62(42)$ \\
\hline 20 & 1000 & $8.19 \pm 0.75(48)$ & $8.50 \pm 0.74(134)$ & $7.76 \pm 0.19(13)$ & $8.73 \pm 1.11(29)$ \\
\hline 21 & 1200 & $9.25 \pm 0.44(6)$ & $8.94 \pm 0.86(25)$ & $7.67(1)$ & $7.71 \pm 0.47(7)$ \\
\hline 22 & 1400 & $9.31 \pm 0.39(6)$ & $9.16 \pm 0.88(15)$ & & $8.16 \pm 0.05(3)$ \\
\hline 23 & 1600 & $9.39 \pm 0.57(12)$ & $8.63 \pm 0.47(44)$ & & $8.47 \pm 0.12(5)$ \\
\hline 24 & 1800 & $9.85 \pm 0.26(4)$ & $9.08 \pm 0.34(10)$ & & $9.04 \pm 0.07(8)$ \\
\hline 25 & 2000 & $9.10 \pm 0.92(7)$ & $8.79 \pm 0.28(24)$ & & $8.87 \pm 0.09$ \\
\hline 26 & 2500 & $9.51 \pm 0.65(6)$ & $8.81 \pm 0.36(5)$ & & $8.93 \pm 0.02(11)$ \\
\hline$\underline{\mathrm{SL}}$ & SLD & \multicolumn{4}{|c|}{ Continental Shelf (station bottom depth $\leq 200 \mathrm{~m}$ ) } \\
\hline 1 & 0 & $0.84 \pm 0.34(56)$ & $0.52 \pm 0.27(130)$ & $0.44 \pm 0.18(33)$ & $0.72 \pm 0.26(93)$ \\
\hline 2 & 5 & $2.45 \pm 1.07(134)$ & $0.66 \pm 0.46(330)$ & $0.36 \pm 0.15(104)$ & $0.83 \pm 0.21(194)$ \\
\hline 3 & 10 & $2.38 \pm 0.96(132)$ & $1.11 \pm 0.46(247)$ & $0.45 \pm 0.18$ & $0.84 \pm 0.23(93)$ \\
\hline 4 & 20 & $1.01 \pm 0.52(82)$ & $0.59 \pm 0.34(296)$ & $0.56 \pm 0.22(102)$ & $0.76 \pm 0.19(125)$ \\
\hline 5 & 30 & $2.66 \pm 0.85(132)$ & $1.14 \pm 0.35(237)$ & $0.79 \pm 0.33(50)$ & $0.82 \pm 0.21(116)$ \\
\hline 6 & 40 & $2.81 \pm 0.73(116)$ & $1.08 \pm 0.48(272)$ & $0.49 \pm 0.24(85)$ & $0.91 \pm 0.20(103)$ \\
\hline 7 & 50 & $1.52 \pm 0.60(23)$ & $1.15 \pm 0.35(165)$ & $0.77 \pm 0.30(37)$ & $1.02 \pm 0.29(49)$ \\
\hline 8 & 60 & $3.37 \pm 0.56(97)$ & $1.45 \pm 0.43(221)$ & $0.79 \pm 0.46(55)$ & $1.46 \pm 0.53(86)$ \\
\hline 9 & 80 & $3.37 \pm 0.82(89)$ & $1.74 \pm 0.60(270)$ & $1.67 \pm 0.63(77)$ & $1.84 \pm 0.59(76)$ \\
\hline 10 & 100 & $2.73 \pm 1.18(45)$ & $2.48 \pm 0.70(172)$ & $2.10 \pm 0.52(38)$ & $2.47 \pm 0.68$ \\
\hline 11 & 120 & $2.00 \pm 1.04(21)$ & $2.82 \pm 0.67(49)$ & $2.38 \pm 0.45(11)$ & $3.72 \pm 0.74(9)$ \\
\hline 12 & 160 & $2.79 \pm 1.04(11)$ & $3.32 \pm 0.44(36)$ & $2.87 \pm 0.46(8)$ & $3.12 \pm 0.16(12)$ \\
\hline 13 & 200 & $3.71 \pm 0.00(2)$ & $3.53 \pm 0.32(3)$ & & $3.65 \pm 1.47(2)$ \\
\hline
\end{tabular}

Table S7. - Chlorophyll $a$ concentration ( $\left.\mu \mathrm{g} \mathrm{L}^{-1}\right)$ with depth and stratification of the water column in the Catalan Sea (NW Mediterranean Sea). Shown are median \pm median absolute deviation (number of data between parentheses). SL, Standard Level; SLD, Standard Level Depth (m).

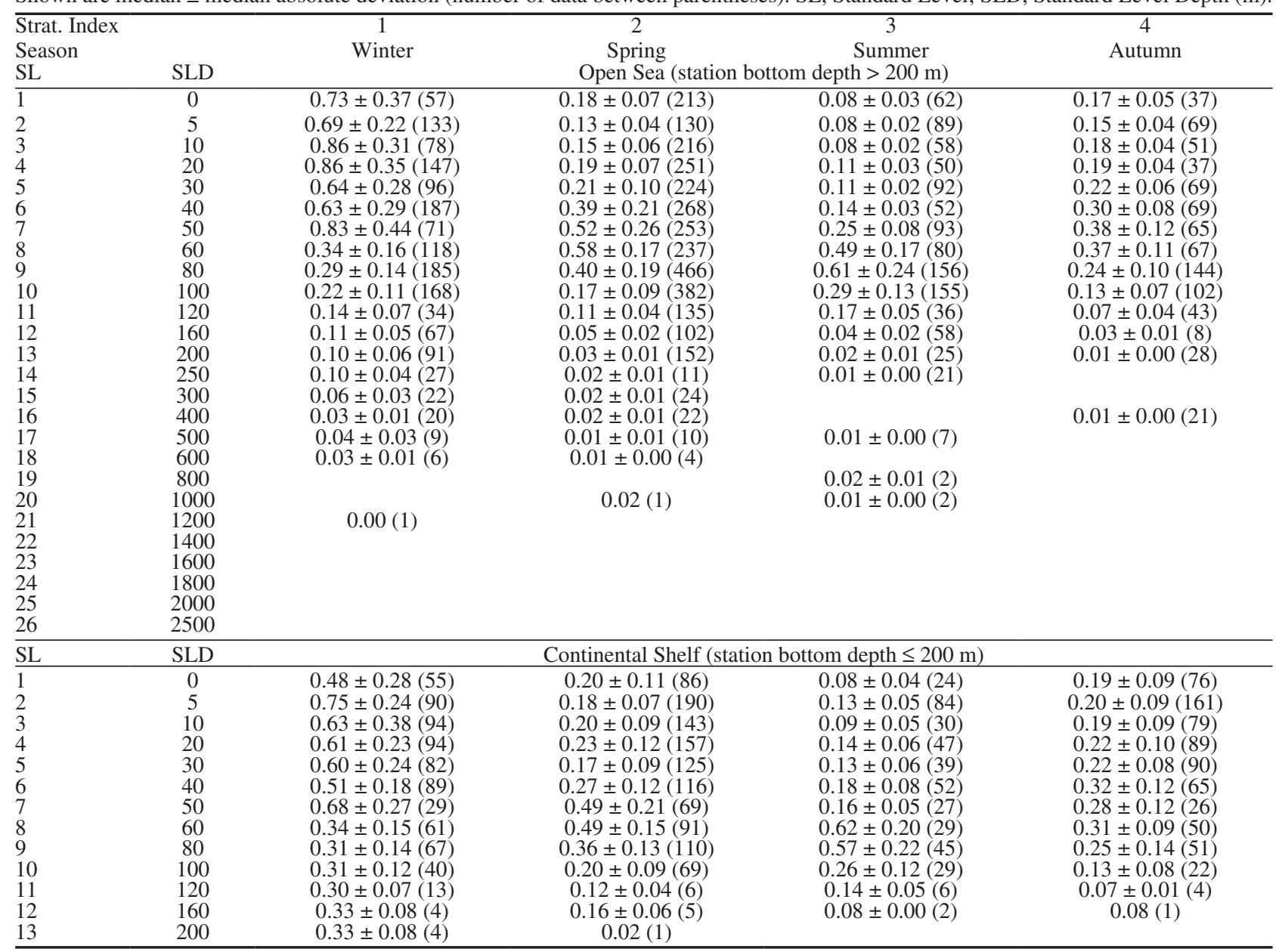


Table S8. - Dissolved oxygen concentration ( $\mu \mathrm{M})$ with depth and stratification of the water column in the Catalan Sea (NW Mediterranean Sea). Shown are median \pm median absolute deviation (number of data between parentheses). SL, Standard Level; SLD, Standard Level Depth (m).

\begin{tabular}{|c|c|c|c|c|c|}
\hline $\begin{array}{l}\text { Strat. Index } \\
\text { Season } \\
\text { SL } \\
\end{array}$ & SLD & $\begin{array}{c}1 \\
\text { Winter }\end{array}$ & \multicolumn{2}{|c|}{$\begin{array}{cc}2 & 3 \\
\text { Spring } & \text { Summer } \\
\text { Open Sea } & \text { (station bottom depth }>200 \mathrm{~m} \text { ) }\end{array}$} & $\begin{array}{c}4 \\
\text { Autumn }\end{array}$ \\
\hline$\overline{1}$ & 0 & $253.89 \pm 10.05(202)$ & $243.84 \pm 11.16(228)$ & $213.03 \pm 6.70(65)$ & $235.36 \pm 6.25(58)$ \\
\hline 2 & 5 & $261.10 \pm 9.22(133)$ & $239.77 \pm 10.22(285)$ & $216.60 \pm 9.83(77)$ & $235.89 \pm 5.58(92)$ \\
\hline 3 & 10 & $257.43 \pm 8.74(172)$ & $246.07 \pm 9.83(317)$ & $219.50 \pm 9.60(54)$ & $235.36 \pm 4.47(93)$ \\
\hline 4 & 20 & $255.45 \pm 8.49(235)$ & $252.33 \pm 12.06(381)$ & $241.16 \pm 14.51(66)$ & $235.36 \pm 5.81(78)$ \\
\hline 5 & 30 & $255.01 \pm 7.63(211)$ & $261.71 \pm 10.88(402)$ & $258.58 \pm 14.29(79)$ & $238.04 \pm 6.70(108)$ \\
\hline 6 & 40 & $252.80 \pm 8.51(145)$ & $260.91 \pm 9.92(345)$ & $272.87 \pm 11.16(51)$ & $245.65 \pm 9.38(82)$ \\
\hline 7 & 50 & $251.88 \pm 8.04(159)$ & $255.45 \pm 13.53(422)$ & $269.30 \pm 8.49(83)$ & $246.52 \pm 10.27(95)$ \\
\hline 8 & 60 & $246.73 \pm 8.94(138)$ & $246.52 \pm 10.81(324)$ & $262.15 \pm 8.49(53)$ & $240.04 \pm 13.17(57)$ \\
\hline 9 & 80 & $242.95 \pm 9.83(264)$ & $238.48 \pm 10.27(707)$ & $238.48 \pm 12.50(128)$ & $233.41 \pm 11.45(151)$ \\
\hline 10 & 100 & $238.71 \pm 10.50(276)$ & $231.07 \pm 8.67(602)$ & $226.47 \pm 6.92(116)$ & $219.13 \pm 7.44(120)$ \\
\hline 11 & 120 & $229.55 \pm 8.04(43)$ & $227.54 \pm 10.05(320)$ & $225.31 \pm 8.26$ & $216.15 \pm 5.81(59)$ \\
\hline 12 & 160 & $223.30 \pm 11.61(153)$ & $221.56 \pm 9.33(279)$ & $218.39 \pm 7.15(76)$ & $211.69 \pm 7.62(80)$ \\
\hline 13 & 200 & $217.94 \pm 11.16(213)$ & $215.26 \pm 8.49(331)$ & $220.62 \pm 7.59(59)$ & $204.76 \pm 6.92(108)$ \\
\hline 14 & 250 & $211.24 \pm 10.72(133)$ & $207.22 \pm 8.49(193)$ & $215.93 \pm 9.38(54)$ & $199.85 \pm 9.16(56)$ \\
\hline 15 & 300 & $205.88 \pm 9.83(200)$ & $201.41 \pm 7.74(275)$ & $211.24 \pm 7.59(51)$ & $195.70 \pm 8.75(59)$ \\
\hline 16 & 400 & $197.84 \pm 9.53(200)$ & $196.50 \pm 8.18(229)$ & $201.64 \pm 6.03(40)$ & $197.40 \pm 7.59(93)$ \\
\hline 17 & 500 & $195.61 \pm 9.25(187)$ & $193.82 \pm 7.49(227)$ & $202.08 \pm 5.14(32)$ & $189.80 \pm 6.25(48)$ \\
\hline 18 & 600 & $201.64 \pm 8.26(130)$ & $194.28 \pm 7.15(120)$ & $200.97 \pm 7.15(17)$ & $196.28 \pm 6.92(38)$ \\
\hline 19 & 800 & $200.52 \pm 6.70(165)$ & $195.45 \pm 6.11(174)$ & $202.31 \pm 4.02(19)$ & $201.86 \pm 4.02(37)$ \\
\hline 20 & 1000 & $202.31 \pm 4.39(154)$ & $201.84 \pm 3.10(95)$ & $204.54 \pm 2.23(13)$ & $204.99 \pm 5.77(23)$ \\
\hline 21 & 1200 & $202.75 \pm 2.23(93)$ & $201.52 \pm 3.97(20)$ & $209.01(1)$ & $199.63 \pm 4.91(13)$ \\
\hline 22 & 1400 & $203.65 \pm 1.34(73)$ & $203.62 \pm 3.39(18)$ & & $199.63 \pm 4.47(10)$ \\
\hline 23 & 1600 & $205.43 \pm 1.34(83)$ & $206.37 \pm 3.26(30)$ & $207.44 \pm 6.92(2)$ & $201.86 \pm 0.89(5)$ \\
\hline 24 & 1800 & $206.77 \pm 1.34(57)$ & $208.84 \pm 3.23(6)$ & $209.90(1)$ & $196.50(1)$ \\
\hline 25 & 2000 & $206.33 \pm 1.34(67)$ & $204.42 \pm 1.30(10)$ & $210.35(1)$ & $202.75 \pm 3.57(3)$ \\
\hline 26 & 2500 & $206.33 \pm 0.89(55)$ & $205.71 \pm 0.91(4)$ & & $205.88 \pm 1.34(2)$ \\
\hline$\underline{\mathrm{SL}}$ & SLD & \multicolumn{4}{|c|}{ Continental Shelf (station bottom depth $\leq 200 \mathrm{~m}$ ) } \\
\hline 1 & 0 & $262.91 \pm 6.61(90)$ & $251.88 \pm 16.97(113)$ & $211.64 \pm 8.22(32)$ & $231.78 \pm 8.49(99)$ \\
\hline 2 & 5 & $269.96 \pm 10.94(130)$ & $238.48 \pm 11.97(216)$ & $209.90 \pm 8.71(32)$ & $233.35 \pm 6.47(156)$ \\
\hline 3 & 10 & $266.00 \pm 10.11(144)$ & $239.38 \pm 11.66(241)$ & $213.03 \pm 9.38(31)$ & $230.44 \pm 7.37(108)$ \\
\hline 4 & 20 & $259.35 \pm 7.05(116)$ & $254.11 \pm 12.96(190)$ & $232.23 \pm 22.78(31)$ & $231.11 \pm 8.26(110)$ \\
\hline 5 & 30 & $260.37 \pm 7.27(134)$ & $257.26 \pm 9.48(202)$ & $260.81 \pm 12.50(31)$ & $235.80 \pm 6.32(110)$ \\
\hline 6 & 40 & $259.33 \pm 5.94(109)$ & $262.60 \pm 6.78(170)$ & $267.51 \pm 7.15(29)$ & $242.06 \pm 6.69(58)$ \\
\hline 7 & 50 & $248.75 \pm 11.16(39)$ & $255.18 \pm 12.24(114)$ & $268.40 \pm 5.58(30)$ & $242.95 \pm 7.59(47)$ \\
\hline 8 & 60 & $253.04 \pm 7.31(78)$ & $250.39 \pm 9.23(125)$ & $248.53 \pm 7.82(12)$ & $242.64 \pm 9.13(50)$ \\
\hline 9 & 80 & $249.30 \pm 6.62(84)$ & $239.57 \pm 12.25(181)$ & $239.82 \pm 12.06(25)$ & $236.70 \pm 6.39(47)$ \\
\hline 10 & 100 & $249.38 \pm 8.48(37)$ & $230.89 \pm 9.32(107)$ & $225.98 \pm 11.16(13)$ & $230.22 \pm 7.16(22)$ \\
\hline 11 & 120 & $243.36 \pm 4.36(17)$ & $225.93 \pm 6.78(35)$ & $229.55 \pm 12.06(3)$ & $218.21 \pm 8.53(5)$ \\
\hline 12 & 160 & $246.80 \pm 7.55(10)$ & $224.67 \pm 8.54$ (14) & & $217.12 \pm 2.31(2)$ \\
\hline 13 & 200 & $239.48(1)$ & $235.40 \pm 2.22(3)$ & & $215.40(1)$ \\
\hline
\end{tabular}

Table S9. - Salinity with depth and stratification of the water column in the Catalan Sea (NW Mediterranean Sea). Shown are average \pm standard deviation (number of data between parentheses). SL, Standard Level; SLD, Standard Level Depth (m).

\begin{tabular}{|c|c|c|c|c|c|}
\hline \multicolumn{2}{|c|}{$\begin{array}{l}\text { Strat. Index } \\
\text { Season }\end{array}$} & $\begin{array}{c}1 \\
\text { Winter }\end{array}$ & \multicolumn{2}{|c|}{$\begin{array}{cc}2 \\
\text { Spring } & 3 \\
\text { Open Sea (station bottom depth }>200 \mathrm{~m} \text { ) }\end{array}$} & $\begin{array}{c}4 \\
\text { Autumn }\end{array}$ \\
\hline 1 & 0 & $38.10 \pm 0.19(48)$ & $37.88 \pm 0.33(161)$ & $37.68 \pm 0.26(29)$ & $37.85 \pm 0.07(15)$ \\
\hline 2 & 5 & $37.97 \pm 0.29(166)$ & $37.70 \pm 0.32(384)$ & $37.71 \pm 0.29(53)$ & $37.90 \pm 0.13(64)$ \\
\hline 3 & 10 & $38.09 \pm 0.18(70)$ & $37.88 \pm 0.28(269)$ & $37.62 \pm 0.30(25)$ & $37.83 \pm 0.08(38)$ \\
\hline 4 & 20 & $38.12 \pm 0.17(151)$ & $37.89 \pm 0.26(436)$ & $37.77 \pm 0.29(48)$ & $37.94 \pm 0.13(60)$ \\
\hline 5 & 30 & $38.10 \pm 0.15(108)$ & $37.94 \pm 0.25(404)$ & $37.78 \pm 0.31(37)$ & $37.97 \pm 0.11(57)$ \\
\hline 6 & 40 & $38.14 \pm 0.16(190)$ & $38.01 \pm 0.22(465)$ & $37.93 \pm 0.24(38)$ & $38.05 \pm 0.13(76)$ \\
\hline 7 & 50 & $38.18 \pm 0.07(52)$ & $38.07 \pm 0.20$ & $37.95 \pm 0.29(35)$ & $38.13 \pm 0.13(44)$ \\
\hline 8 & 60 & $38.18 \pm 0.15(160)$ & $38.10 \pm 0.17(465)$ & $38.02 \pm 0.25(63)$ & $38.12 \pm 0.11(80)$ \\
\hline 9 & 80 & $38.19 \pm 0.15(214)$ & $38.15 \pm 0.14(880)$ & $38.08 \pm 0.21(115)$ & $38.19 \pm 0.11(125)$ \\
\hline 10 & 100 & $38.20 \pm 0.15(208)$ & $38.21 \pm 0.12(732)$ & $38.17 \pm 0.15(103)$ & $38.23 \pm 0.10(87)$ \\
\hline 11 & 120 & $38.25 \pm 0.12(34)$ & $38.26 \pm 0.11(335)$ & $38.20 \pm 0.13(35)$ & $38.33 \pm 0.09(38)$ \\
\hline 12 & 160 & $38.25 \pm 0.15(101)$ & $38.29 \pm 0.13(288)$ & $38.28 \pm 0.11(47)$ & $38.30 \pm 0.07(36)$ \\
\hline 13 & 200 & $38.28 \pm 0.16(145)$ & $38.34 \pm 0.11(442)$ & $38.32 \pm 0.07(36)$ & $38.40 \pm 0.07(76)$ \\
\hline 14 & 250 & $38.28 \pm 0.14(55)$ & $38.41 \pm 0.09$ & $38.39 \pm 0.09(22)$ & $38.42 \pm 0.04(9)$ \\
\hline 15 & 300 & $38.38 \pm 0.14(122)$ & $38.44 \pm 0.10(310)$ & $38.41 \pm 0.04(29)$ & $38.47 \pm 0.03(24)$ \\
\hline 16 & 400 & $38.49 \pm 0.08(120)$ & $38.47 \pm 0.16(271)$ & $38.44 \pm 0.04(32)$ & $38.49 \pm 0.03(67)$ \\
\hline 17 & 500 & $38.51 \pm 0.07(95)$ & $38.50 \pm 0.05(292)$ & $38.43 \pm 0.05(13)$ & $38.51 \pm 0.01(13)$ \\
\hline 18 & 600 & $38.51 \pm 0.07(41)$ & $38.50 \pm 0.11(156)$ & $38.51 \pm 0.01(10)$ & $38.51 \pm 0.01(18)$ \\
\hline 19 & 800 & $38.52 \pm 0.05(51)$ & $38.49 \pm 0.02(202)$ & $38.47 \pm 0.04(9)$ & $38.50 \pm 0.01(18)$ \\
\hline 20 & 1000 & $38.48 \pm 0.05(65)$ & $38.46 \pm 0.08(161)$ & $38.44 \pm 0.04(5)$ & $38.47 \pm 0.01(19)$ \\
\hline 21 & 1200 & $38.52 \pm 0.04(15)$ & $38.47 \pm 0.02(32)$ & $38.47 \pm 0.02(2)$ & $38.46 \pm 0.01(2)$ \\
\hline 22 & 1400 & $38.48 \pm 0.09(5)$ & $38.45 \pm 0.02(27)$ & & \\
\hline 23 & 1600 & $38.44 \pm 0.03(20)$ & $38.45 \pm 0.02(56)$ & & \\
\hline 24 & 1800 & $38.45 \pm 0.03(4)$ & $38.45 \pm 0.01(17)$ & & \\
\hline 25 & 2000 & $38.45 \pm 0.01(10)$ & $38.45 \pm 0.02(24)$ & & \\
\hline 26 & 2500 & $38.44 \pm 0.02(6)$ & $38.45 \pm 0.01(5)$ & & \\
\hline SL & SLD & & Continental Shelf (s & tom depth $\leq 200 \mathrm{~m}$ ) & \\
\hline 1 & 0 & $37.88 \pm 0.19(9)$ & $37.68 \pm 0.29(26)$ & $37.36 \pm 0.05(3)$ & \\
\hline 2 & 5 & $37.45 \pm 0.59(136)$ & $37.57 \pm 0.31(293)$ & $37.75 \pm 0.28$ & $37.89 \pm 0.21(110)$ \\
\hline 3 & 10 & $37.55 \pm 0.36(127)$ & $37.64 \pm 0.24(255)$ & $37.56 \pm 0.32(5)$ & $37.68 \pm 0.00$ \\
\hline 4 & 20 & $37.91 \pm 0.37(63)$ & $37.73 \pm 0.29(166)$ & $37.89 \pm 0.22(45)$ & $37.95 \pm 0.15(48)$ \\
\hline 5 & 30 & $37.82 \pm 0.30(132)$ & $37.82 \pm 0.21(233)$ & $37.87 \pm 0.25(16)$ & $37.96 \pm 0.03(65)$ \\
\hline 6 & 40 & $37.91 \pm 0.26(138)$ & $37.87 \pm 0.18(266)$ & $37.99 \pm 0.16(33)$ & $38.01 \pm 0.06(91)$ \\
\hline 7 & 50 & $38.03 \pm 0.33(23)$ & $37.91 \pm 0.23(131)$ & $37.78 \pm 0.18(6)$ & $38.02 \pm 0.05(8)$ \\
\hline 8 & 60 & $38.03 \pm 0.17(121)$ & $37.95 \pm 0.16(227)$ & $38.01 \pm 0.12(26)$ & $38.04 \pm 0.03(86)$ \\
\hline 9 & 80 & $38.08 \pm 0.13(90)$ & $37.98 \pm 0.16(246)$ & $38.05 \pm 0.11(38)$ & $38.09 \pm 0.03(83)$ \\
\hline 10 & 100 & $38.11 \pm 0.12(42)$ & $38.03 \pm 0.15(149)$ & $38.11 \pm 0.09(20)$ & $38.15 \pm 0.07(44)$ \\
\hline 11 & 120 & $38.07 \pm 0.12(19)$ & $38.11 \pm 0.12(46)$ & $38.15 \pm 0.07(7)$ & $38.19 \pm 0.07(10)$ \\
\hline 12 & 160 & $38.16 \pm 0.10(11)$ & $38.18 \pm 0.06(23)$ & $38.18 \pm 0.01(3)$ & $38.21 \pm 0.06(11)$ \\
\hline 13 & 200 & $38.11 \pm 0.15(5)$ & $38.27 \pm 0.12(4)$ & & $38.39(1)$ \\
\hline
\end{tabular}


Table S10. - Potential temperature $\left({ }^{\circ} \mathrm{C}\right)$ with depth and stratification of the water column in the Catalan Sea (NW Mediterranean Sea). Shown are average \pm standard deviation (number of data between parentheses). SL, Standard Level; SLD, Standard Level Depth (m).

\begin{tabular}{|c|c|c|c|c|c|}
\hline $\begin{array}{l}\text { Strat. Index } \\
\text { Season } \\
\text { SL } \\
\end{array}$ & SLD & \multicolumn{3}{|c|}{$\begin{array}{l}\text { Spring } \\
\text { Open Sea (station bottom depth }>200 \mathrm{~m} \text { ) }\end{array}$} & $\begin{array}{c}4 \\
\text { Autumn }\end{array}$ \\
\hline 1 & 0 & $13.59 \pm 0.66(47)$ & $18.42 \pm 2.74(165)$ & $25.86 \pm 0.62(29)$ & $19.44 \pm 0.64(15)$ \\
\hline 2 & 5 & $13.22 \pm 0.55(167)$ & $20.20 \pm 1.61(384)$ & $25.70 \pm 0.88(53)$ & $20.17 \pm 2.07(64)$ \\
\hline 3 & 10 & $13.34 \pm 0.60(69)$ & $18.50 \pm 2.38(270)$ & $24.68 \pm 1.52(24)$ & $18.80 \pm 1.05(38)$ \\
\hline 4 & 20 & $13.32 \pm 0.57(151)$ & $17.29 \pm 2.00(437)$ & $20.52 \pm 1.69(46)$ & $19.77 \pm 2.16(60)$ \\
\hline 5 & 30 & $13.15 \pm 0.42(105)$ & $16.05 \pm 1.66(404)$ & $17.84 \pm 1.30(37)$ & $17.98 \pm 1.34(57)$ \\
\hline 6 & 40 & $13.20 \pm 0.46(190)$ & $14.77 \pm 1.14(466)$ & $15.84 \pm 1.19(39)$ & $17.15 \pm 2.26(76)$ \\
\hline 7 & 50 & $13.26 \pm 0.45(51)$ & $14.03 \pm 0.90(450)$ & $14.66 \pm 0.76(35)$ & $15.10 \pm 1.53(44)$ \\
\hline 8 & 60 & $13.10 \pm 0.31(160)$ & $13.67 \pm 0.70(466)$ & $14.03 \pm 0.61(62)$ & $14.84 \pm 1.45(80)$ \\
\hline 9 & 80 & $13.12 \pm 0.41(214)$ & $13.36 \pm 0.47(875)$ & $13.55 \pm 0.47(114)$ & $14.03 \pm 1.04(125)$ \\
\hline 10 & 100 & $13.07 \pm 0.40(207)$ & $13.14 \pm 0.28(730)$ & $13.31 \pm 0.32(98)$ & $13.59 \pm 0.59(87)$ \\
\hline 11 & 120 & $13.12 \pm 0.30(34)$ & $13.02 \pm 0.18(336)$ & $13.21 \pm 0.23(34)$ & $13.30 \pm 0.40(38)$ \\
\hline 12 & 160 & $13.00 \pm 0.28(101)$ & $13.03 \pm 0.20(285)$ & $13.12 \pm 0.13(48)$ & $13.28 \pm 0.10(36)$ \\
\hline 13 & 200 & $13.00 \pm 0.33(145)$ & $13.07 \pm 0.17(441)$ & $13.14 \pm 0.10(35)$ & $13.23 \pm 0.10(76)$ \\
\hline 14 & 250 & $12.98 \pm 0.28(55)$ & $13.04 \pm 0.16(154)$ & $13.08 \pm 0.08(21)$ & $13.19 \pm 0.06(9)$ \\
\hline 15 & 300 & $13.02 \pm 0.21(122)$ & $13.10 \pm 0.15(308)$ & $13.10 \pm 0.10(28)$ & $13.22 \pm 0.06(24)$ \\
\hline 16 & 400 & $13.13 \pm 0.15$ & $13.10 \pm 0.17(271)$ & $13.06 \pm 0.13(32)$ & $13.15 \pm 0.12(67)$ \\
\hline 17 & 500 & $13.11 \pm 0.14(95)$ & $13.11 \pm 0.12(290)$ & $12.93 \pm 0.10(13)$ & $13.18 \pm 0.06(13)$ \\
\hline 18 & 600 & $13.11 \pm 0.16(41)$ & $13.07 \pm 0.13(156)$ & $13.16 \pm 0.03(10)$ & $13.19 \pm 0.05(18)$ \\
\hline 19 & 800 & $13.06 \pm 0.07(51)$ & $13.00 \pm 0.08(202)$ & $13.01 \pm 0.12(9)$ & $13.11 \pm 0.06$ \\
\hline 20 & 1000 & $12.95 \pm 0.07(65)$ & $12.89 \pm 0.06(161)$ & $12.86 \pm 0.05(5)$ & $12.93 \pm 0.10(19)$ \\
\hline 21 & 1200 & $12.91 \pm 0.07(15)$ & $12.87 \pm 0.06(32)$ & $12.97 \pm 0.11(2)$ & $12.89 \pm 0.08(2)$ \\
\hline 22 & 1400 & $12.86 \pm 0.02(5)$ & $12.82 \pm 0.04(27)$ & & \\
\hline 23 & 1600 & $12.85 \pm 0.03(20)$ & $12.81 \pm 0.02(55)$ & & \\
\hline 24 & 1800 & $12.83 \pm 0.02(4)$ & $12.79 \pm 0.01(17)$ & & \\
\hline 25 & 2000 & $12.85 \pm 0.03(10)$ & $12.78 \pm 0.01(24)$ & & \\
\hline 26 & 2500 & $12.85 \pm 0.03(6)$ & $12.78 \pm 0.01(5)$ & & \\
\hline$\overline{\mathrm{SL}}$ & SLD & \multicolumn{4}{|c|}{ Continental Shelf (station bottom depth $\leq 200 \mathrm{~m}$ ) } \\
\hline 1 & 0 & $13.86 \pm 0.91(9)$ & $18.05 \pm 3.16(27)$ & $25.81 \pm 0.56(3)$ & \\
\hline 2 & 5 & $12.79 \pm 0.53(150)$ & $21.37 \pm 1.80(293)$ & $26.24 \pm 1.24(44)$ & $20.51 \pm 1.86(110)$ \\
\hline 3 & 10 & $12.80 \pm 0.53(127)$ & $20.77 \pm 2.21$ & $25.28 \pm 0.76(5)$ & $19.18 \pm 0.14$ \\
\hline 4 & 20 & $13.08 \pm 0.77(63)$ & $17.89 \pm 2.42(165)$ & $19.30 \pm 1.95(45)$ & $20.92 \pm 1.99$ \\
\hline 5 & 30 & $12.84 \pm 0.48(132)$ & $17.68 \pm 2.12(232)$ & $17.45 \pm 2.82(16)$ & $19.23 \pm 0.93(65)$ \\
\hline 6 & 40 & $12.90 \pm 0.53(138)$ & $15.22 \pm 0.98(266)$ & $16.17 \pm 2.57(33)$ & $17.84 \pm 1.81(91)$ \\
\hline 7 & 50 & $12.91 \pm 0.60(23)$ & $14.28 \pm 0.97(131)$ & $14.98 \pm 0.78(6)$ & $16.12 \pm 1.79(8)$ \\
\hline 8 & 60 & $12.98 \pm 0.43(121)$ & $13.94 \pm 0.66(227)$ & $13.88 \pm 0.44(26)$ & $15.71 \pm 1.07(86)$ \\
\hline 9 & 80 & $13.05 \pm 0.52(90)$ & $13.62 \pm 0.51(246)$ & $13.55 \pm 0.30(37)$ & $14.82 \pm 0.95(83)$ \\
\hline 10 & 100 & $13.15 \pm 0.70(42)$ & $13.43 \pm 0.47(149)$ & $13.44 \pm 0.25(20)$ & $14.04 \pm 0.74$ \\
\hline 11 & 120 & $13.17 \pm 0.64(19)$ & $13.27 \pm 0.40(46)$ & $13.39 \pm 0.14(7)$ & $13.58 \pm 0.21(10)$ \\
\hline 12 & 160 & $13.13 \pm 0.69(11)$ & $13.28 \pm 0.20(23)$ & $13.30 \pm 0.05(3)$ & $13.47 \pm 0.10(11)$ \\
\hline 13 & 200 & $13.22 \pm 0.86(5)$ & $13.19 \pm 0.16(4)$ & & $13.17(1)$ \\
\hline
\end{tabular}

Table S11. - Density anomaly $\left(\mathrm{kg} \mathrm{m}^{-3}\right)$ with depth and stratification of the water column in the Catalan Sea (NW Mediterranean Sea). Shown are average \pm standard deviation (number of data between parentheses). SL, Standard Level; SLD, Standard Level Depth (m).

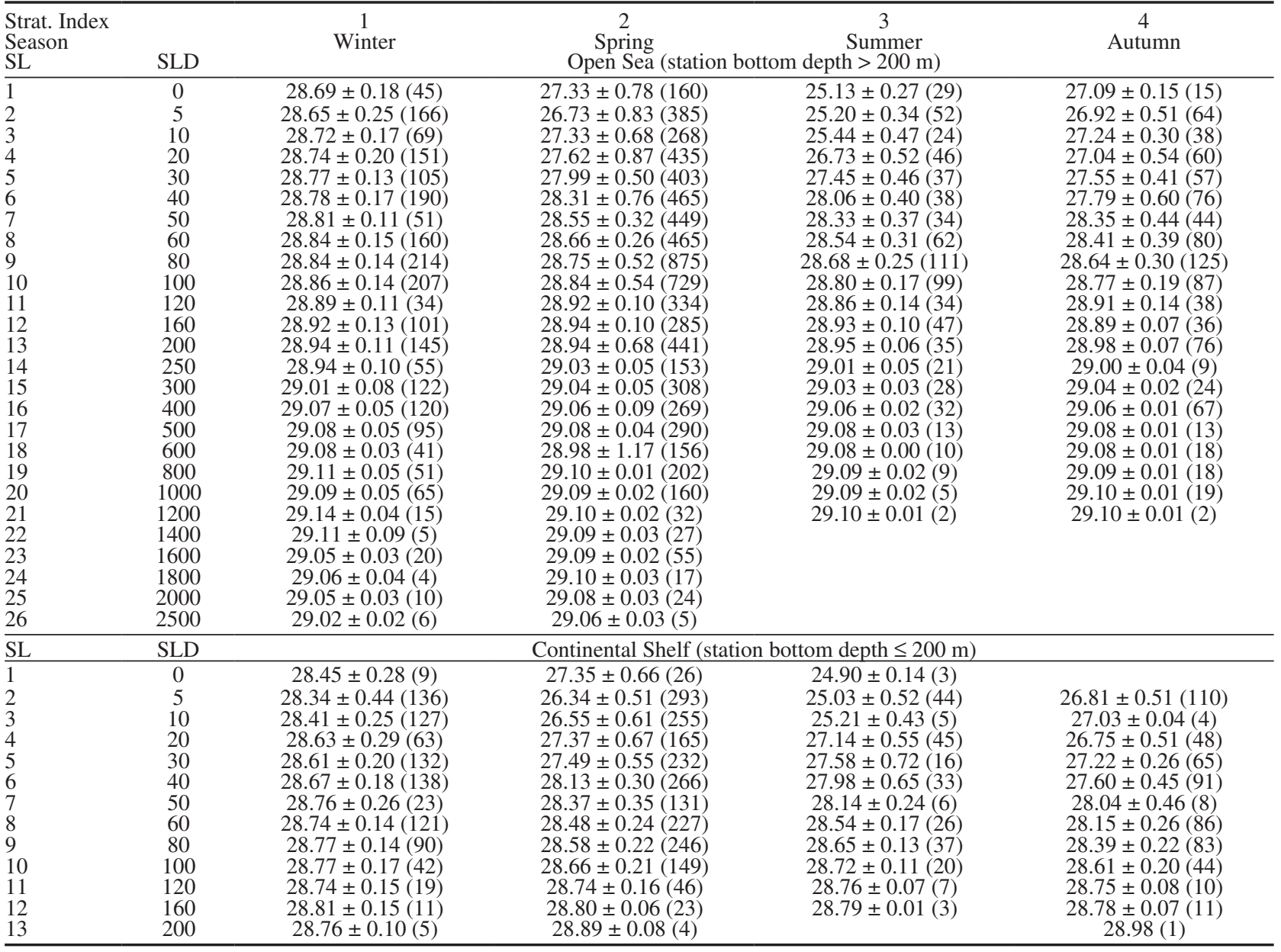



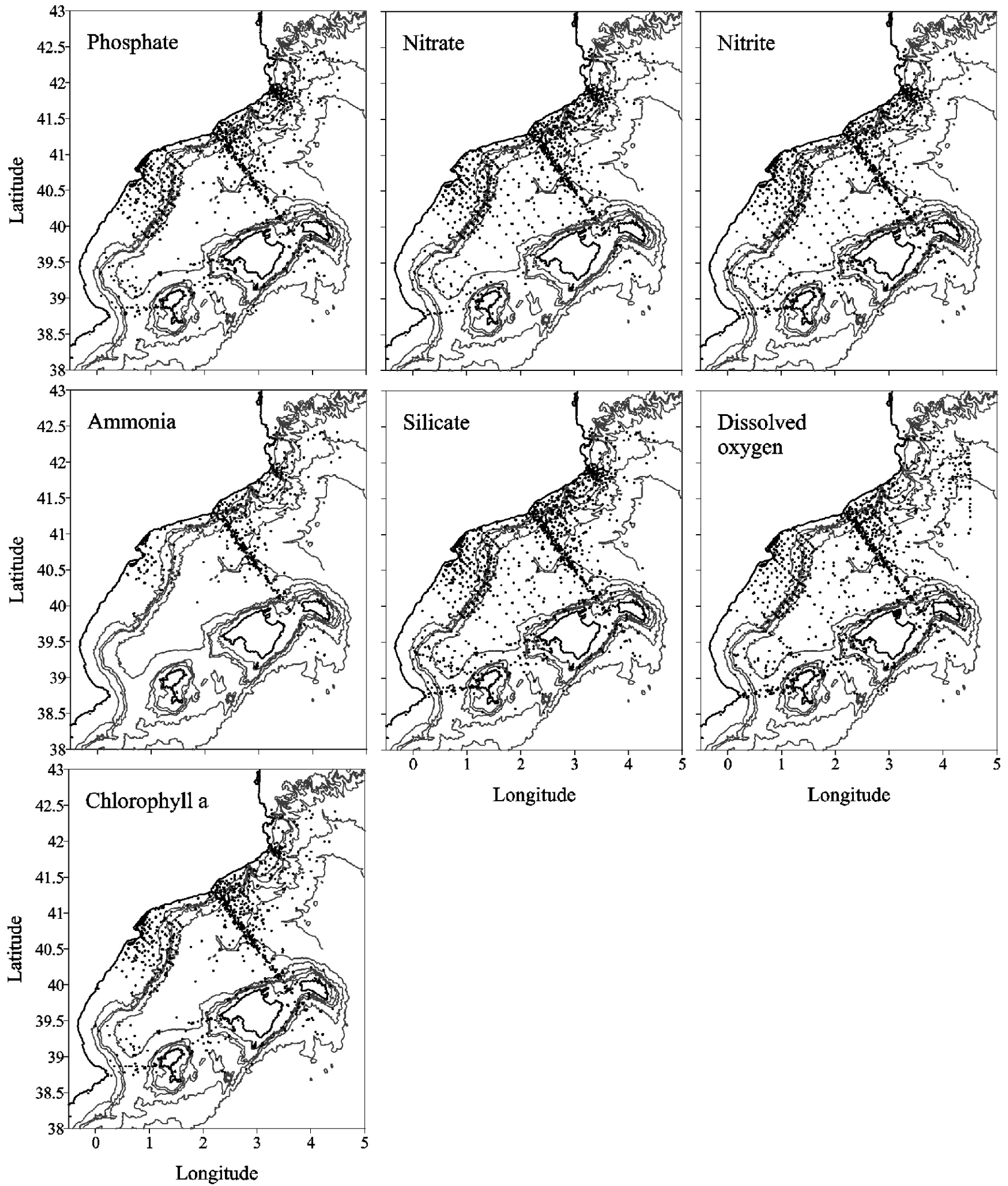

Fig. S1. - Position of oceanographic stations in the Catalan Sea with phosphate, nitrate, nitrite, ammonium, silicate, dissolved oxygen and chlorophyll $a$ data. Isobaths correspond to 100, 200, 400, 1000, 2000 and $2500 \mathrm{~m}$ depth. 